\title{
2 Phase Relations, Reaction Sequences and Petrochronology
}

\author{
Chris Yakymchuk \\ Department of Earth and Environmental Sciences \\ University of Waterloo \\ Waterloo, Ontario, Canada, N2L 3G1 \\ cyakymchuk@uwaterloo.ca \\ Chris Clark \\ Department of Applied Geology \\ Curtin University \\ Perth, Western Australia, Australia, 6102 \\ Richard W. White \\ Earth System Science Research Centre, Institute of Geoscience \\ University of Mainz \\ Mainz, Germany, D-55099
}

petrological evolution of major mineral assemblages. The focus of this chapter is on outlining

INTRODUCTION

some of the available strategies to link inferred reaction sequences and microstructures in metamorphic rocks to the ages obtained from geochronology of accessory minerals and datable major minerals. Reaction sequences and mineral assemblages in metamorphic rocks are primarily a function of pressure $(P)$, temperature $(T)$ and bulk composition $(X)$. Several of the major rock-forming minerals are particularly sensitive to changes in $P-T$ (e.g., garnet, staurolite, biotite, plagioclase), but their direct geochronology is challenging and in many cases not currently possible. One exception is garnet, which can be dated using $\mathrm{Sm}-\mathrm{Nd}$ and $\mathrm{Lu}-\mathrm{Hf}$ geochronology (e.g., Baxter et al. 2013). Accessory mineral chronometers such as zircon, monazite, xenotime, titanite and rutile are stable over a relatively wide range of $P-T$ conditions and can incorporate enough $\mathrm{U}$ and/or $\mathrm{Th}$ to be dated using $\mathrm{U}-\mathrm{Th}-\mathrm{Pb}$ geochronology. Therefore, 
34 linking the growth of $P-T$ sensitive major minerals to accessory and/or major mineral

35 chronometers is essential for determining a metamorphic $P-T-t$ history, which is itself critical

36 for understanding metamorphic rocks and the geodynamic processes that produce them (e.g.,

37 England and Thompson, 1984; McClelland and Lapen 2013; Brown, 2014).

breakdown of the important $P-T$ sensitive minerals requires an understanding of the metamorphic reaction sequences for a particular bulk rock composition along a well-constrained

$41 \quad P-T$ evolution. Fortunately, the phase relations and reaction sequences for the most widely studied metamorphic protoliths (e.g., pelites, greywackes, basalts) can be determined using quantitative phase equilibria forward modelling (e.g., Powell and Holland 2008). Comprehensive activity-composition models of the major metamorphic minerals in large chemical systems (e.g., White et al. 2014a) allow the calculation of phase proportions and compositions for a given rock composition along a metamorphic $P-T$ path. For accessory minerals, subsolidus growth and

47 breakdown can be modelled in some cases using phase equilibria modelling (e.g., Spear 2010;

48 Spear and Pyle 2010). Suprasolidus accessory mineral behaviour can be investigated by coupling 49 phase equilibria modelling with the experimental results of accessory mineral solubility in melt 50 (Kelsey et al. 2008; Yakymchuk and Brown 2014b). This technique provides a basic framework

51 for interpreting the geological significance of accessory mineral ages in suprasolidus 52 metamorphic rocks. In this chapter, we use phase equilibria modelling techniques to investigate the reaction 54 sequences for three common rock types (pelite, greywacke, MORB) along several $P-T$ paths and 55 explore how these sequences relate to accessory mineral growth and dissolution with a particular 56 focus on zircon and monazite and to a lesser extent apatite. First, we review the important major 
57 rock-forming minerals that are used to link metamorphic reaction sequences to trace element

58 chemistries in accessory minerals. Second, we summarize the current understanding of the

59 controls of accessory mineral growth and breakdown in metamorphic rocks during a $P-T$

60 evolution. Third, we use phase equilibria modelling to examine the reaction sequences for

61 common rock types along several schematic $P-T$ paths and discuss the implications for

62 petrochronology. Finally, we examine some of the complicating factors for reconciling the

63 behaviour of accessory minerals in natural systems with the predictions from phase equilibria

64 modelling.

\section{MAJOR MINERALS}

68 important in accessory mineral petrochronology for four reasons. First, major minerals may

69 contain significant quantities of the essential structural constituents of accessory minerals

70 commonly used as chronometers. In some cases, accessory mineral can grow directly from the

71 breakdown of major minerals. Examples of this are zircon growth from the release of $\mathrm{Zr}$ during

72 the breakdown of garnet (Fraser et al. 1997; Degeling et al. 2001) and ilmenite (Bingen et al.

73 2001). Second, these minerals may represent important repositories for trace elements, and thus

74 the growth and breakdown of major minerals will influence the availability of these elements for

75 incorporation by growing accessory minerals. Third, the major minerals are important hosts for

76 inclusions of accessory minerals. The breakdown of the major minerals may liberate included

77 accessory minerals into the reaction volume of the rock or alternatively may sequester these

78 minerals away allowing their preservation when they would otherwise be consumed in a reaction 
sequence (e.g., Montel et al. 2000). Fourth, the microstructural relationships between accessory and major minerals provide context for delineating the $P-T$ history of a metamorphic rock.

Garnet and plagioclase are the major minerals most commonly used in petrochronology

82 because of their distinctive trace element behaviour. Linking their growth and breakdown to ages

83 obtained from accessory mineral chronometers requires an understanding of the bulk

84 composition controls on their stabilities. Below, we outline the controls on the growth and

85 breakdown of garnet and plagioclase, which are of particular importance for petrochronology

86 studies. Our focus is on linking mineral growth to metamorphic reactions and we do not discuss

87 the minerals that are important for thermochronology studies (e.g., amphibole, biotite,

88 muscovite, K-feldspar).

\section{Garnet}

Garnet is one of the most useful minerals for constraining metamorphic grade and its high

92 density and strong partitioning of cations forms the basis of many useful thermobarometers (e.g.,

93 Spear 1995; Caddick and Kohn 2013). It is a common metamorphic mineral for many different

94 protoliths (pelites, mafic rocks, ultramafic rocks, calc-silicates) and has been extensively used in

95 petrochronology studies (e.g., Vance and O’Nions 1990; Vance and Mahar 1998; Harris et al.

96 2004). Coupling $P-T$ estimates from garnet with monazite $\mathrm{U}-\mathrm{Pb}$ geochronology can also be used

97 to constrain $P-T-t$ paths (e.g., Foster et al. 2000; Gibson et al. 2004; Dragovic et al. 2016).

98 Garnet can also be directly dated using $\mathrm{Sm}-\mathrm{Nd}$ and $\mathrm{Lu}-\mathrm{Hf}$ geochronology (e.g., Baxter et al.

99 2013; Baxter et al. 2017, this volume). Although linking $P-T$ information from garnet-bearing

100 assemblages with garnet geochronology is very powerful (e.g., Mulcahy et al. 2014; Dragovic et

101 al. 2012, 2015), direct dating of garnet is challenging and is not yet extensively used. 
An important control on the stability of garnet during metamorphism is the bulk rock

103 MnO content (e.g., Symmes and Ferry 1992; Mahar et al. 1997; White et al. 2014b). For pelites,

104 higher bulk rock Mn concentrations stabilize garnet at lower temperatures in the greenschist

105 facies and at lower pressure in the amphibolite facies (White et al. 2014b). The ratio of Fe/Mg is

106 also an important control on garnet growth. For example, relatively magnesium-rich pelites have

107 restricted garnet stability fields (e.g., White et al. 2014a) and in very Mg-rich bulk rock

108 compositions garnet may not even grow along common $P-T$ paths (e.g., Fitzsimons et al. 2005).

109 Therefore, depending on the bulk composition of the rock, garnet can be first stabilized in the 110 greenschist facies, the amphibolite facies or not at all.

111 Garnet is the most important major mineral sink for the heavy rare earth elements

112 (HREE) and yttrium in metamorphic rocks (Bea et al. 1994). Accessory minerals such as zircon,

113 monazite, xenotime, apatite, epidote and allanite are also important repositories for the HREE

114 and Y. Thus, the growth and breakdown of garnet plays an important role in the HREE and Y

115 budgets in rocks and links the trace element chemistry of accessory mineral chronometers to the

$116 P-T$ information obtained from garnet-bearing metamorphic assemblages (Pyle et al. 2001;

117 Foster et al. 2002; Kohn et al. 2004; Rubatto 2002; Rubatto and Hermann 2007; Taylor et al.

118 2015). In general, the equilibrium distribution coefficients of the HREE between garnet and

119 zircon are close to unity for Gd to Lu at high temperature (Taylor et al. 2015). For Yttrium,

120 concentrations in monazite are $\sim 1.5$ orders of magnitude higher than in garnet (Bea et al. 1994).

121 Xenotime has Y concentrations that are $\sim 2$ orders of magnitude higher than in monazite (Pyle et

122 al. 2001). However, in most cases, garnet is substantially more modally abundant than monazite

123 and xenotime and thus the breakdown or growth of garnet will exert first-order controls on the $\mathrm{Y}$

124 and HREE budget of the rock. Zircon and monazite crystallization during garnet growth will 
125 result in relatively low concentrations of HREE and Y in these minerals because these elements

126 are partitioned into garnet. By contrast, garnet breakdown during accessory mineral growth can

127 result in HREE- and Y-enriched trace element concentrations of the new growth zones of

128 accessory minerals (e.g., Rubatto 2002; Foster et al. 2002, 2004).

\section{Plagioclase}

Plagioclase is extremely common in metamorphic rocks and is stable over a wide range

132 of $P-T$ conditions. Plagioclase breakdown with increasing pressure is an important part of the 133 reaction sequences for high-pressure metamorphic rocks and eclogites. Similar to garnet,

134 plagioclase is commonly a key mineral in thermobarometers that provides important $P-T$

135 information in many different rock types (Ghent 1976; Wu 2015; Molina et al. 2015). For

136 petrochronology, plagioclase (and to a lesser extent K-feldspar) strongly partitions Eu and $\mathrm{Sr}$

137 over the other major rock-forming minerals (e.g., Gromet and Silver 1983). The growth and 138 breakdown of plagioclase can be tied to Eu anomalies in rare earth element patterns of accessory

139 minerals (Rubatto et al. 2013; Holder et al. 2015; Regis et al. 2016). Strontium concentrations

140 have been used to link accessory mineral growth to the timing of plagioclase breakdown; this is a

141 particularity important relationship in ultrahigh pressure metamorphic rocks (Finger and Krenn

142 2007; Kylander-Clark et al. 2013; Holder et al. 2015).

\section{ACCESSORY MINERALS}

145 Like the major minerals, accessory minerals are involved in the reaction sequence

146 experienced by metamorphic rocks. The behaviour of some accessory minerals used in

147 petrochronology such as epidote, titanite and rutile can be quantified along a $P-T$ evolution using 
148 phase equilibria modelling. However, the behaviour of zircon and monazite - the most

149 commonly used mineral chronometers - is more difficult to quantify with current phase

150 equilibria modelling techniques (e.g., Spear and Pyle 2010; Kelsey and Powell 2011) as they

151 contain key elements commonly not considered in model chemical systems.

153 Epidote

154 Epidote is common in low-medium pressure metabasites, metamorphosed intermediate

155 rocks and calc-silicates (e.g., Grapes and Hoskin 2004) as well as in high- to ultrahigh-pressure

156 metamorphic rocks (e.g., Enami et al. 2004). The chemical controls on epidote stability are

157 mainly bulk rock concentrations of $\mathrm{Ca}$ and $\mathrm{Al}$ as well as $f_{\mathrm{O} 2}$ (e.g., Enami et al. 2004). The

158 epidote-group minerals can be important repositories for $\mathrm{Zr}$ (e.g., Frei et al. 2004; Kohn et al.

159 2015) and LREE in metamorphic rocks (Frei et al. 2004; Janots et al. 2008). Therefore, the

160 breakdown of Zr-rich epidote may have the potential to generate metamorphic zircon. Coupled

161 allanite and epidote breakdown may produce new monazite (e.g., Janots et al. 2008) if there is

162 also a source of phosphorus such as xenotime or apatite.

163

164 Titanite

165 Titanite is common in mafic rocks and in some low-grade metasedimentary rocks and it 166 can be used as a barometer in metabasites (e.g., Kapp et al. 2009). An important factor in the 167 stability of titanite is the relative activities of $\mathrm{Ca}$ and $\mathrm{Al}$ as influenced by the bulk rock ratio of

$168 \mathrm{Ca}$ to $\mathrm{Al}$ and the accompanying mineral assemblage. High Ca activities favour titanite over

169 ilmenite and high Al activities favour anorthite (and ilmenite) over titanite (Frost et al. 2001).

170 Consequently, titanite is a common mineral in low-Al compositions such as calc-silicate and 
171 mafic rocks whereas aluminous metasedimentary rocks generally have ilmenite as the main Ti-

172 bearing mineral above the greenschist facies.

173 Titanite can be directly dated using U-Pb geochronology, but there is some uncertainty

174 about the closure temperature for $\mathrm{Pb}$, which is generally considered to be around $600^{\circ} \mathrm{C}$ (Warren

175 et al. 2012; Spencer et al. 2013; Stearns et al. 2015; Kirkland et al. 2016), depending on cooling

176 rate. Diffusion profiles of trace elements in titanite can be used to determine the timing and

177 duration of cooling (e.g., geospeedometry) and this is covered in more detail in Kohn (2017, this

178 volume). Titanite thermometry uses the $\mathrm{Zr}$ concentration of titanite to estimate temperature

179 (Hayden et al. 2008). However, application of this thermometer requires an estimate of titania

180 activity $\left(a_{\mathrm{TiO} 2}\right)$, which, in the absence of rutile, is difficult to constrain and can vary along a

181 metamorphic evolution depending on the reaction sequences and mineral assemblages as

182 discussed below.

183

184 Rutile

185 Rutile is commonly stable in relatively reduced bulk rock compositions (e.g., Diener and

186 Powell 2010) and is particularity useful in high-pressure metamorphic rocks (Zack and Kooijman

187 2017). Similar to titanite, rutile can be directly dated with U-Pb geochronology (e.g., Mezger et

188 al. 1989; Clark et al. 2000; Zack et al. 2011; Ewing et al. 2015) and it can be used as a

189 geospeedometer (Smye and Stockli 2014). One of the main uses of rutile is as a thermometer that

190 uses the Zr concentration of rutile to estimate temperature (Zack et al. 2004; Watson et al. 2006;

191 Ferry and Watson 2007; Tomkins et al. 2007; Hofmann et al. 2013; Taylor-Jones and Powell

192 2015). These applications are discussed in more detail by Zack and Kooijman (2017, this

193 volume). 
Metamorphic reaction sequences with or without rutile have important implications for

195 applying the Ti-in-quartz thermometer (e.g., Chambers and Kohn 2012; Ashley and Law 2015)

196 and the Ti-in-zircon thermometer (e.g., Ferry and Watson 2007), both of which use $a_{\mathrm{TiO} 2}$ as a

197 variable. In rutile-bearing systems $a_{\mathrm{TiO} 2}$ is buffered at 1.0. In rutile-absent systems, application of

198 the thermometer requires an estimate of $a_{\mathrm{TiO} 2}$ that is less that 1.0. Figure 1 shows the difference

199 of calculated temperatures using the Ti-in-quartz thermometer (Wark and Watson 2006) and the

200 Ti-in-zircon thermometer (Ferry and Watson 2007) as a function of temperature for a range of

$201 a_{\mathrm{TiO} 2}$ values.

202 For example, consider an amphibolite-facies rock at $650^{\circ} \mathrm{C}$ with a true $a_{\mathrm{TiO} 2}$ value 0.6 . If

203 an $a_{\mathrm{TiO} 2}$ value of 1.0 is assumed for Ti-in-quartz thermometry, the result would underestimate the

204 true temperature by $\sim 50^{\circ} \mathrm{C}$ (Fig. 1a). Similarly, using an $a_{\mathrm{TiO} 2}$ value of 1.0 when the true value is

2050.6 , the Ti-in-zircon thermometer would underestimate the true temperature by $\sim 40^{\circ} \mathrm{C}(\mathrm{Fig} 1 \mathrm{~b})$.

206 Phase equilibria modelling provides one method of determining $a_{\mathrm{TiO} 2}$ in metamorphic rocks at

207 different stages of a $P-T$ evolution in rutile-absent rocks (e.g., Ashley and Law 2015). We

208 explore this in more detail during our discussion of particular reaction sequences.

210 Zircon

211 Zircon is the main repository of $\mathrm{Zr}$ in most igneous and metamorphic rocks and is the

212 most widely used accessory mineral for U-Pb geochronology (Hoskin and Schaltegger 2003;

213 Rubatto 2017, this volume). Many metamorphic rocks contain relict zircon that may be detrital

214 or igneous in origin and may also be inherited from a previous metamorphic event. For

215 petrochronology, metamorphic zircon can be used to date different portions of a $P-T$ evolution

216 depending on the growth mechanisms. The main processes that increase the mode of zircon in 
217 metamorphic rocks include solid-state growth and the crystallization from anatectic melt. In

218 some cases, zircon may precipitate from hydrothermal fluids (e.g., Schaltegger, 2007).

219 Solid-state zircon growth can occur from the breakdown of other Zr-rich minerals such as

220 garnet (Fraser et al. 1997; Degeling et al. 2001), ilmenite (Bingen et al. 2001), rutile (Ewing et

221 al. 2014) and possibly amphibole (Sláma et al. 2007). This zircon can be used to date major

222 metamorphic assemblage changes during prograde (e.g., Fraser et al. 1997) or retrograde

223 metamorphism (e.g., Degeling et al. 2001) depending on when the Zr-rich mineral breaks down

224 during the reaction sequence. However, major minerals such as garnet, rutile and hornblende can

225 accommodate more $\mathrm{Zr}$ as temperature increases and, in general, zircon will be consumed and

226 prograde zircon growth is expected to be limited (Kohn et al. 2015).

227 The crystallization of anatectic melt typically drives new zircon growth in suprasolidus

228 metamorphic rocks (Watson 1996; Roberts and Finger 1997; Schaltegger et al. 1999; Vavra et al.

229 1999; Hermann et al. 2001; Kelsey et al. 2008; Yakymchuk and Brown 2014b). Experimental

230 studies show that the concentration of $\mathrm{Zr}$ in melt needed to maintain equilibrium with zircon

231 increases with temperature (e.g., Harrison and Watson 1983; Gervasoni et al. 2016) and the

232 compositional parameter $M$, which is the cation ratio of $[\mathrm{Na}+\mathrm{K}+2 \mathrm{Ca}] /[\mathrm{Al} \times \mathrm{Si}]$ (Watson and

233 Harrison 1983; Boehnke et al. 2013). Generally, the concentration of Zr needed for saturation of

234 intermediate melts (high $M$ values) is higher than for more felsic melts (low $M$ values). In

235 suprasolidus metamorphic rocks, the most important factor is the amount of anatectic melt

236 present in the system (Kelsey et al. 2008; Kelsey et al. 2011; Yakymchuk and Brown 2014b). As

237 the fraction of melt increases during prograde metamorphism, zircon is expected to break down

238 to maintain $\mathrm{Zr}$ saturation of the melt in an equilibrated system. Consequently, prograde zircon

239 growth is expected to be limited above the solidus. In general, melt crystallization during cooling 
240 from peak $T$ is expected to be the main mechanism for zircon growth in suprasolidus

241 metamorphic rocks. This is supported by ranges of concordant ages that reflect protracted zircon

242 growth during melt crystallization from peak $T$ in migmatites (e.g., Korhonen et al. 2013b, 243 2014).

244 New zircon growth can also occur at the expense of pre-existing zircon with no change in

245 the mode of zircon in the rock. Recrystallization of metamict zircon in the presence of a fluid

246 may be an important factor for some prograde zircon (e.g., Rubatto and Hermann 2003; Hay and

247 Dempster 2009). Ostwald ripening has been proposed as a mechanism that could produce

248 prograde growth of zircon in suprasolidus metamorphic rocks (Vavra et al. 1999; Nemchin et al.

249 2001; Kawakami et al. 2013). Ostwald ripening (or second phase coarsening) is a process

250 whereby small solids are preferentially dissolved and precipitate on existing larger solids to

251 reduce the total surface free energy (e.g., Tikare and Cawley 1998). While this process has been

252 studied and debated for the major minerals in metamorphic rocks (Miyazaki 1991, 1996; Carlson

$2531999,2000)$ it has not been as extensively studied for accessory minerals - an exception being

254 Nemchin et al. (2001). Nonetheless, it is a possible mechanism for prograde growth of zircon in

255 suprasolidus metamorphic rocks, though involving no net modal increase in zircon.

256 Zircon can also be used as a thermometer in igneous and metamorphic rocks. The Ti-in-

257 zircon thermometer has been increasingly applied to high-temperature metamorphic rocks over

258 the last decade. Kelsey and Hand (2015) compiled Ti-in-zircon temperatures from UHT rocks

259 and noted that $62 \%$ of the results fall below the UHT threshold of $900^{\circ} \mathrm{C}$. One of the possible

260 reasons for this discrepancy is that some UHT rocks do not contain rutile and are therefore

261 undersaturated in $\mathrm{TiO}_{2}\left(a_{\mathrm{TiO} 2}<1.0\right)$. Values of $a_{\mathrm{TiO} 2}$ can range from 1.0 when rutile is in

262 equilibrium with growing zircon to values as low as 0.6 (e.g., Hiess et al. 2008). Using a value of 
2631.0 when rutile is absent will underestimate the true temperature. Again, the presence and

264 absence of rutile during a reaction sequence has important consequences for applying mineral

265 thermometers in metamorphic rocks.

266

267 Monazite

268 Monazite is generally more reactive than zircon in subsolidus metamorphic rocks and has

269 been extensively used for U-Pb geochronology in aluminous bulk compositions (e.g., Parrish

270 1990; Engi 2017, this volume). Monazite can be detrital in origin (Smith and Barreiro 1990;

271 Kingsbury et al. 1993; Suzuki et al. 1994; Rubatto et al. 2001), produced through solid-state

272 reactions (e.g., Rubatto et al. 2001; Wing et al. 2003), precipitated from a fluid (e.g., Ayers et al.

273 1999) or can crystallize from anatectic melt (e.g., Stepanov et al. 2012).

274 Solid-state monazite growth during prograde metamorphism occurs from the breakdown

275 of LREE-rich precursors, which can include: allanite for high-Ca bulk compositions (Spear and

276 Pyle 2010; Wing et al. 2003; Finger et al. 2016), LREE-rich clays (Copeland et al. 1971), Th or

277 LREE oxides and hydrous phosphates (Spear and Pyle 2002). The most studied solid-state

278 reaction is the growth of monazite at the expense of allanite in bulk compositions with sufficient

279 Ca and LREE to grow allanite at lower grade (e.g., Janots et al. 2008). In natural examples, this

280 reaction has been spatially correlated with the garnet-in isograd (Catlos et al. 2001; Foster et al.

281 2004), the staurolite-in isograd (Smith and Barriero 1990; Kohn and Malloy 2004; Corrie and

282 Kohn 2008) and the kyanite or sillimanite-in isograds (Wing et al. 2003; Štípská et al. 2015).

283 Spear (2010) used phase equilibria modelling to examine the $P-T$ conditions of the

284 allanite to monazite transition in several bulk rock compositions relative to the average pelite of

285 Shaw (1956). The reaction boundaries for monazite-in at the expense of allanite for these various 
compositions are summarized in Figure 2. A higher bulk rock $\mathrm{CaO}$ concentration allows allanite

287 to persist to higher temperatures whereas a higher $\mathrm{Al}_{2} \mathrm{O}_{3}$ concentration stabilizes monazite at

288 lower temperatures. However, the results of this modelling of monazite growth in rocks with 289 variable bulk rock $\mathrm{Al}_{2} \mathrm{O}_{3}$ concentrations by Spear (2010) are different to those observed in some

290 natural examples. For example, Wing et al. (2003) found that pelites from New England with

291 relatively elevated $\mathrm{Ca}$ and/or $\mathrm{Al}$ concentrations can preserve allanite to higher temperatures.

292 Gasser et al. (2012) found no link between bulk rock concentrations of $\mathrm{CaO}$ and $\mathrm{Al}_{2} \mathrm{O}_{3}$ and the

293 timing of monazite growth. Therefore, the bulk compositional controls of monazite growth at the 294 expense of allanite are not always clear, but it appears that monazite can grow at a range of 295 temperatures and pressures along a prograde $P-T$ path.

The relative amounts of iron and magnesium in a bulk rock composition may also play an

297 important role in the reactions that produce subsolidus monazite. For example, Fitzsimons et al.

298 (2005) showed that monazite in pelitic schists from Western Australia was generated during 299 garnet-breakdown to staurolite and was interpreted to record the timing of peak metamorphism.

300 However, samples that were too magnesium-rich to grow garnet or too iron-rich to grow 301 staurolite at the expense of garnet yielded older monazite ages. Fitzsimons et al. (2005)

302 interpreted these older ages to represent greenschist-facies monazite growth.

303 In suprasolidus metamorphic rocks, monazite breakdown and growth is controlled mainly

304 by dissolution into and crystallization from anatectic melt. Experimental studies demonstrate that 305 monazite dissolution into melt is a function of temperature, pressure, and the bulk composition of 306 the melt (Montel 1986; Rapp and Watson 1986; Rapp et al. 1987; Skora and Blundy 2012;

307 Stepanov et al. 2012; Duc-Tin and Keppler 2015). The solubility of monazite increases with 308 higher $\mathrm{H}_{2} \mathrm{O}$ concentrations in melt (Stepanov et al. 2012) and with decreasing phosphorus 
concentrations in the melt (Duc-Tin and Keppler 2015). Studies that couple experimentally-

310 determined solubility equations of monazite with phase equilibria modelling show that monazite

311 dissolution increases during prograde metamorphism above the solidus and that for UHT

312 metamorphism most monazite will be completely consumed along the prograde path (Kelsey et

313 al. 2008; Yakymchuk and Brown 2014b). Based on these theoretical models of monazite

314 behaviour, no prograde monazite growth is expected above the solidus. This contrasts with

315 studies of natural rocks that record prograde suprasolidus monazite growth (e.g., Hermann and

316 Rubatto 2003; Hacker et al. 2015). Johnson et al. (2015) suggest that apatite dissolution during

317 prograde metamorphism may have contributed to LREE saturation of the melt and resulted in

318 prograde suprasolidus monazite crystallization. However, the role of apatite breakdown and

319 monazite growth in suprasolidus metamorphic rocks is still poorly understood.

320 Finally, similar to zircon, Ostwald ripening could produce prograde monazite growth in

321 suprasolidus metamorphic rocks (e.g., Nemchin and Bodorkos 2000). However, this has not been

322 extensively studied and may only apply to monazite growth just above the solidus where the

323 modal proportion of anatectic melt is relatively low.

\section{Xenotime}

326 Xenotime is a common phosphate in low- to high-grade metamorphic rocks (e.g., Franz

327 et al. 1996; Bea and Montero 1999; Pyle and Spear 1999; Spear and Pyle 2002). It can be

328 directly dated using U-Pb geochronology (e.g., Parrish 1990; Rasmussen et al. 2005, 2007,

329 Sheppard et al. 2007; Janots et al. 2009; Crowley et al. 2009) and can be used as a thermometer

330 when in equilibrium with monazite and garnet (Pyle et al. 2001). Some of the proposed

331 mechanisms of metamorphic xenotime growth are: (1) growth due to dissolution/reprecipitation 
332 of detrital or diagenetic zircon (Dawson et al. 2003; Rasmussen et al. 2011), (2) growth during to

333 the breakdown of detrital zircon (Franz et al. 2015), (3) growth during the breakdown of allanite

334 and/or monazite (Janots et al. 2008), (4) crystallization from anatectic melt (Pyle and Spear

335 1999; Crowley et al. 2009), and (5) growth during the breakdown of Y-rich garnet (e.g., Pyle and

336 Spear 1999).

337 There are three important controls on the stability of xenotime in metamorphic rocks.

338 First, higher bulk rock Yttrium concentrations allow xenotime to persist to higher pressures and

339 temperatures (Spear and Pyle 2010). Second, similar to monazite and zircon, partial melting will

340 result in xenotime consumption in order to contribute to REE and P saturation of the melt (e.g.,

341 Wolf and London 1995; Duc-Tin and Keppler 2015). Third, xenotime will be consumed during

342 the growth of garnet, which partitions Y and HREE (Pyle and Spear 1999, 2000; Spear and Pyle

343 2002). Consequently, xenotime in the matrix of high-grade garnet-bearing rocks is relatively rare

344 although xenotime inclusions may be present in garnet (e.g., Pyle and Spear 1999). By contrast,

345 xenotime may be present in the matrix at various metamorphic grades in garnet-absent rocks.

PHASE EQUILIBRIA MODELLING

348 Phase assemblages in metamorphic rocks generally change through continuous or

349 multivariant reactions rather than discontinuous or univariant reactions (e.g., Stüwe and Powell

350 1995; Kelsey and Hand 2015). Petrogenetic grids display discontinuous reactions and may yield

351 the false impression that reactions occur over narrow intervals along a $P-T$ path (e.g., Vernon

352 1996). In reality, mineral (and melt) modes and compositions are continuously changing along a

$353 P-T$ evolution and these variations represent the reaction sequence of the rock. The particular

354 reaction sequence experienced by a metamorphic rock is dependent on bulk composition, the $P$ - 
355 T path and whether the system is open or closed (e.g., White and Powell 2002; Brown and

356 Korhonen 2009; Yakymchuk and Brown 2014a). The phase assemblages expected for a

357 particular bulk rock composition over a range of $P-T$ conditions are commonly depicted using

$358 \quad P-T$ pseudosections, phase diagrams constructed for a fixed bulk composition (e.g., Hensen

359 1971; Worley et al. 1998; Spear et al. 2016). More detailed information about the reaction

360 sequences can be determined by using the intersection of a $P-T$ path with isopleths (or contours)

361 of different variables (e.g., mineral modes and compositions) on a pseudosection or by

362 constructing mode-temperature or mode-pressure diagrams (e.g., White et al. 2011).

363 Here, we present pseudosections and mode-box diagrams ( $P / T$-mode plots) for different

364 bulk chemical compositions to investigate the reaction sequences along common $P-T$ paths and

365 we discuss the consequences for interpreting the ages obtained from accessory mineral

366 geochronology. The effects of fractionation of growing porphyroblasts and changes in bulk

367 composition are discussed later. Because we use phase equilibria modelling, it is assumed that

368 there are no kinetic controls (e.g., nucleation barriers or sluggish diffusion) that impact the

369 growth or dissolution of major and accessory minerals. Although this assumption may not be

370 strictly valid in some circumstances (Watt and Harley 1993; Pattison and Tinkham 2009; Gaides

371 et al. 2011; Pattison and Debuhr 2015), the modelling here provides a general framework for

372 investigating reaction sequences.

373

374 Bulk compositions

375 Three bulk chemical compositions are modelled that represent the most common

376 protoliths investigated during most metamorphic studies. For the subsolidus and suprasolidus $P-$

$377 T$ paths, this includes an average amphibolite-facies metapelite (Ague 1991) and an average 
378 passive margin greywacke (Yakymchuk and Brown 2014a). These two compositions were

379 chosen because they are expected to dominate passive margin turbidite sequences that are

380 involved in orogenesis at convergent plate boundaries. A mid-ocean ridge basalt (MORB) from

381 Sun and McDonough (1989) was also used to investigate a suprasolidus reaction sequence for a

382 typical mafic protolith. The modelled bulk compositions are summarized in Table 1. Note that

383 we do not consider melt loss nor fractionation of minerals away from the reacting volume in the

384 modelling here, both of which can modify the composition of the equilibrium volume during a

385 metamorphic evolution (e.g., White and Powell 2002; Evans 2004; Guevara and Caddick 2016;

386 Mayne et al. 2016).

388 Computational Methods

389 Forward phase equilibria modelling is used to evaluate the changes to metamorphic

390 mineral assemblages along several schematic $P-T$ paths. There are two main approaches to phase

391 equilibria modelling. The first approach is to use Gibbs free energy minimization to determine

392 the stable mineral assemblage at a given $P-T$ condition and there are two commonly used

393 software packages available for this approach, including Perple_X (Connolly and Petrini 2002)

394 and Theriak-Domino (de Capitani and Brown 1987; de Capitani and Petrakakis 2010). A second

395 approach is to determine the solution of simultaneous non-linear equations to build up an array

396 of points and lines that make up a metamorphic phase diagram (THERMOCALC: Powell and

397 Holland 1988; Powell et al. 1998; Powell and Holland 2008). Both of these approaches require

398 an internally consistent thermodynamic database derived from the results of experimental

399 studies. There are several commonly-used databases available: Berman (1988), Holland and

400 Powell (1998) and most recently Holland and Powell (2011). Finally, the calculations require 
401 activity-composition models that relate end-member proportions to end-member activities for 402 the solid-solution minerals as well as for complex fluids and melt.

403 Here, calculations were performed using THERMOCALC v.3.40 (Powell and Holland 1988)

404 using the internally consistent dataset of Holland and Powell (2011). For metapelite and

405 greywacke compositions, modelling was undertaken in the $\mathrm{MnO}-\mathrm{Na} 2 \mathrm{O}-\mathrm{CaO}-\mathrm{K}_{2} \mathrm{O}-\mathrm{FeO}-\mathrm{MgO}-$

$406 \mathrm{Al}_{2} \mathrm{O}_{3}-\mathrm{SiO}_{2}-\mathrm{H}_{2} \mathrm{O}-\mathrm{TiO}_{2}-\mathrm{Fe}_{2} \mathrm{O}_{3}$ (MnNCKFMASHTO) chemical system using the activity-

407 composition relations in White et al. $(2014 a, b)$. An average MORB composition was

408 investigated in the NCKFMASHTO chemical system using the activity-composition models

409 from Green et al. (2016). Phases modelled as pure end-members are quartz, rutile, titanite,

410 aqueous fluid $\left(\mathrm{H}_{2} \mathrm{O}\right)$, kyanite and sillimanite. Mineral abbreviations are from Holland and Powell

411 (2011) with the exception of titanite (ttn).

412 Phase equilibria modelling of subsolidus and suprasolidus systems requires different

413 approaches to approximate the bulk $\mathrm{H}_{2} \mathrm{O}$ content of the system. For subsolidus phase equilibria

414 modelling, the amount of $\mathrm{H}_{2} \mathrm{O}$ in each bulk composition was set to be in excess, such that $a_{\mathrm{H} 2 \mathrm{O}}$

$415=1$. By contrast, suprasolidus rocks are generally not considered to have excess $\mathrm{H}_{2} \mathrm{O}$ as the very

416 small amount of free $\mathrm{H}_{2} \mathrm{O}$ at the solidus is partitioned into anatectic melt (Huang and Wyllie

417 1973; Thompson 1982; Clemens and Vielzeuf 1987; White and Powell 2002; White et al. 2005).

418 Along the solidus, the solubility of $\mathrm{H}_{2} \mathrm{O}$ in anatectic melt increases with pressure. Therefore, for

419 phase equilibria modelling of suprasolidus rocks, the amount of $\mathrm{H}_{2} \mathrm{O}$ in the bulk composition

420 must be set, and was adjusted so that the melt is just saturated with $\mathrm{H}_{2} \mathrm{O}$ at solidus at 8 kbar. If

421 the modelled prograde path crossed the solidus at lower or higher pressures, the quantity of melt

422 produced will be slightly overestimated and underestimated, respectively. 


\section{Modelled $\boldsymbol{P}-\boldsymbol{T}$ paths}

425

Several simplified typical $P-T$ paths for subsolidus and suprasolidus systems are modelled to investigate the reaction sequences, changes in mineral modes, amount of melt generated and/or consumed, variations in bulk rock $a_{\mathrm{TiO} 2}$ and the consequences for interpreting the results of accessory mineral geochronology. Two subsolidus and two suprasolidus $P-T$ paths were investigated for the metapelite and greywacke compositions that represent different tectonic evolutions. We also model one suprasolidus $P-T$ path for a MORB composition applicable to high-pressure mafic granulites.

For the subsolidus systems, the first $P-T$ path has a clockwise trajectory and is representative of collisional orogenesis (e.g., England and Thompson 1984; Thompson and England 1984). An important feature of this $P-T$ path is that peak $P$ occurs before peak $T$, which is consistent with a relatively long residence time in the core of an orogenic belt. The model path ('clockwise' in Figs 3, 5) contains four segments: (1) heating and burial up to $10 \mathrm{kbar}$ and $550^{\circ} \mathrm{C},(2)$ isobaric heating up to $650^{\circ} \mathrm{C},(3)$ decompression and minor heating to $8 \mathrm{kbar}$ and $660^{\circ} \mathrm{C}$, and (4) decompression and cooling to $6.2 \mathrm{kbar}$ and $610^{\circ} \mathrm{C}$.

The second subsolidus $P-T$ path has a 'hairpin' trajectory where peak $P$ and peak $T$ nearly coincide (e.g., 'hairpin' in Figs 3,5 ). This style of $P-T$ path is also common in collisional orogenesis (e.g., Brown 1998; Kohn 2008) and reflects relatively short residence times at depth and can represent crustal thickening in an accretionary zone of a propagating orogen (Jamieson et al. 2004). The model hairpin $P-T$ path contains three segments: (1) heating and burial up to 7 kbar and $610^{\circ} \mathrm{C},(2)$ heating and decompression to $6 \mathrm{kbar}$ and $650^{\circ} \mathrm{C}$, and (3) decompression and cooling to $4 \mathrm{kbar}$ and $600^{\circ} \mathrm{C}$. Peak metamorphism is at the same temperature for both subsolidus $P-T$ paths, but the pressures at peak $T$ are different. 
Two $P-T$ paths for suprasolidus rocks that are typical of granulite-facies metamorphism 448 are investigated. First, a clockwise $P-T$ path is modelled (e.g., 'clockwise' in Figs 7,9 ) that is 449 associated with crustal thickening and heating and is typical of many granulite terranes (e.g., 450 Clark et al. 2011). This $P-T$ path contains four segments: (1) increase in pressure and heating 451 across the solidus up to 9 kbar at $850^{\circ} \mathrm{C}$, (2) isobaric heating up to $900^{\circ} \mathrm{C}$, (3) isothermal 452 decompression to $7 \mathrm{kbar}$, and (4) cooling and decompression to $5 \mathrm{kbar}$ at $750^{\circ} \mathrm{C}$. Second, a suprasolidus counterclockwise (or anticlockwise) $P-T$ path is considered (e.g.,

454 'counterclockwise' in Figs 7, 9) and is common in high temperature-low pressure terranes (e.g., 455 Clarke et al. 1987; Collins and Vernon 1991) and some ultrahigh temperature terrains (e.g., 456 Korhonen et al. 2013a, 2014). This $P-T$ path reflects heating prior to thickening (usually at peak $457 T$ ) followed by near-isobaric cooling. In some cases, this has been attributed to the inversion of a 458 hot back-arc basin during collisional orogenesis (Clark et al. 2014). The modelled 459 counterclockwise $P-T$ path contains four segments: (1) isobaric heating up to $830^{\circ} \mathrm{C}$ and $5 \mathrm{kbar}$, 460 (2) heating and an increase in pressure up to $860^{\circ} \mathrm{C}$ and $6 \mathrm{kbar}$, (3) cooling and an increase in 461 pressure to $850^{\circ} \mathrm{C}$ and $7 \mathrm{kbar}$, and (4) isobaric cooling to $750^{\circ} \mathrm{C}$.

462 A high-pressure clockwise path was also chosen to model the reaction sequences for 463 high-pressure mafic granulites (e.g., O’Brien and Rötzler 2003) and to investigate the growth and 464 breakdown of garnet for these rocks. This $P-T$ path contains four segments: (1) heating and an 465 increase in pressure up to $12 \mathrm{kbar}$ and $850^{\circ} \mathrm{C}$, (2) isobaric heating up to $950^{\circ} \mathrm{C}$, (3) isothermal 466 decompression to $8 \mathrm{kbar}$, and (4) cooling and decompression to $800^{\circ} \mathrm{C}$ and $6 \mathrm{kbar}$. The 467 decompression segments of this $P-T$ path are also compatible with the decompression segments 468 of some ultrahigh-pressure metamorphic rocks (Hacker et al. 2010; Chen et al 2013; Xu et al 469 2013). 
471 Modelling suprasolidus zircon and monazite dissolution

For the suprasolidus $P-T$ paths, the growth and dissolution of zircon and monazite are

473 modelled using the method of Kelsey et al. (2008). Note that the bulk composition used in this

474 modelling is fixed without fractionation of elements into growing porphyroblasts (e.g., zirconium

475 into garnet) or loss of melt. These factors are discussed later. First, the saturation concentrations

476 of the melt in ppm are calculated as follows. The major element composition of the anatectic

477 melt is calculated at a specified $P-T$. This composition of the melt is combined with the

478 solubility equations of Boehnke et al. (2013) for zircon and Stepanov et al. (2012) for monazite,

479 and the stoichiometric concentrations of $\mathrm{Zr}$ in zircon $(497,664 \mathrm{ppm} \mathrm{Zr})$ and LREE in monazite

480 (566,794 ppm LREE) to determine the saturation concentrations of Zr and LREE in ppm (Kelsey

481 et al. 2008). These initial calculations do not account for the proportion of anatectic melt or the

482 bulk-rock concentrations of $\mathrm{Zr}$ and LREE. Second, the saturation concentrations of $\mathrm{Zr}$ or LREE

483 (ppm) are multiplied by the proportion of anatectic melt in the system (in normalized mol\%

484 which is approximately equivalent to vol\%) at $P-T$ to arrive at concentrations in ppm that are

485 required to saturate the melt in the equilibration volume of the rock. Finally, these values are

486 divided by the assumed bulk-rock chemical concentrations of $\mathrm{Zr}$ and LREE. The $\mathrm{Zr}$ and LREE in

487 pelites and the greywackes are generally similar to each other and to the values of

488 metasedimentary migmatites; a value of 150 ppm was chosen here (e.g., Yakymchuk and Brown

489 2014b). For MORB, the Zr concentration was set at 103 ppm, which is an average of global

490 MORB compositions (White and Klein 2014). The sensitivity of these calculations to bulk rock

491 concentrations of $\mathrm{Zr}$ and LREE and the assumptions and limitations of this methodology are

492 discussed by Kelsey et al. (2008) and Yakymchuk and Brown (2014b). The result of the 
493 calculations is the proportion of zircon or monazite dissolution required to saturate the anatectic

494 melt in $\mathrm{Zr}$ and LREE in the equilibration volume of the rock. This value is subtracted from $100 \%$

495 and the results are reported as the percent of zircon and monazite remaining relative to the

496 amounts existing at the fluid-present solidus for each $P-T$ path.

497 One important limitation of the monazite saturation equation used here is that it does not

498 account for phosphorus in anatectic melt, which can affect monazite stability (e.g., Duc-Tin and

499 Keppler 2015). The main repository of phosphorus in most metamorphic rocks is apatite, which

500 is expected to break down during partial melting (Wolf and London 1994). Phosphorus

501 saturation in melt is a function of temperature, $\mathrm{SiO}_{2}$ concentration (Harrison and Watson 1984)

502 and the aluminum saturation index of the melt $\left(\mathrm{ASI}=\operatorname{molar}\left[\mathrm{Al}_{2} \mathrm{O}_{3}\right] /\left[\mathrm{K}_{2} \mathrm{O}+\mathrm{Na}_{2} \mathrm{O}+\mathrm{CaO}\right]\right.$,

503 Wolf and London 1994). The solubility of apatite in melt increases with rising ASI, which is

504 common during prograde partial melting in migmatites (e.g., Johnson et al. 2015). For example,

505 an increase in the ASI from 1.1 to 1.2 increases the solubility of apatite by an order of magnitude

506 (Wolf and London 1994). The breakdown of LREE-rich apatite during prograde metamorphism

507 may contribute to LREE saturation of anatectic melt and monazite crystallization (e.g., Johnson

508 et al. 2015; Rocha et al. 2016). Here, we use melt ASI as a qualitative tool to investigate the

509 behaviour of apatite during partial melting and the consequences for prograde monazite growth

510 in suprasolidus metamorphic rocks.

\section{SUBSOLIDUS PHASE RELATIONS AND REACTION SEQUENCES}

513 Phase relations and reaction sequences for two subsolidus $P-T$ paths for two bulk compositions

514 are discussed below for a closed system where bulk composition does not change. Fractionation

515 of porphyroblasts away from the reacting volume is not considered in the calculations here. 


\section{Metapelite}

Phase relations. The pseudosection for the amphibolite-facies metapelite is shown in

519 Figure 3. Biotite is stable at $T>450-460^{\circ} \mathrm{C}$ with increasing pressure. Garnet is stable across most of the diagram except at low $P$ and low $T$ and at $P<5$ kbar just below the solidus. The

521 staurolite-in field boundary extends from $550^{\circ} \mathrm{C}$ at $4 \mathrm{kbar}$ up to $650^{\circ} \mathrm{C}$ at $10 \mathrm{kbar}$. The stability

522 field of the aluminosilicate minerals (kyanite and sillimanite) ranges from $T>580^{\circ} \mathrm{C}$ at $4 \mathrm{kbar}$ to

$523 T>660^{\circ} \mathrm{C}$ at $10 \mathrm{kbar}$. Rutile is stable at low $P$ at low temperatures and at $P>10.5$ at $T>550^{\circ} \mathrm{C}$.

Reaction sequence for the clockwise $P-T$ path. A mode-box for the reaction sequence

526 for the clockwise $P-T$ path is shown in Figure 4a. During the prograde segment of the clockwise $527 P-T$ path, chlorite is progressively consumed to produce biotite (starting at $455^{\circ} \mathrm{C}$ ) and then 528 garnet (starting at $460^{\circ} \mathrm{C}$ ). Chlorite is exhausted by $580^{\circ} \mathrm{C}$. Rutile is completely consumed by $529 \sim 530^{\circ} \mathrm{C}$. Epidote breaks down along the prograde path and the epidote-out field boundary is 530 encountered at $620^{\circ} \mathrm{C}$. The complete breakdown of epidote at $620^{\circ} \mathrm{C}$ may result in minor zircon 531 crystallization or more likely the growth of new rims on pre-existing zircon.

The staurolite stability field is encountered during the heating and decompression

533 segment at $9 \mathrm{kbar}$ and $650^{\circ} \mathrm{C}$. In natural examples, prograde monazite growth has been

534 associated with garnet, staurolite and kyanite/sillimanite growth in metapelites (Catlos et al.

535 2001; Smith and Barriero 1990; Wing et al. 2003; Kohn and Malloy 2004; Fitzsimons et al.

536 2005; Corrie and Kohn 2008), although kyanite/sillimanite is not encountered along the $P-T$ path

537 modelled here. In general, monazite could grow at different points along the prograde $P-T$ path.

538 Because garnet growth is predicted to be continuous up to the staurolite-in field boundary, new 
monazite grown during this segment of the $P-T$ path is expected to have low concentrations of

540 HREE and Y; these elements are expected to partition into garnet. Staurolite growth is at the

541 expense of garnet and occurs during the decompression portion of the prograde path (e.g.,

542 Florence and Spear 1993). Monazite formed during this segment is expected to have elevated

543 HREE and Y concentrations due to the breakdown of garnet and the age would record the initial

544 stages of decompression from peak $P$. By contrast, zircon is expected to undergo only minor

545 changes to its mode and will be slightly consumed during subsolidus prograde metamorphism

546 (e.g., Kohn et al. 2015). Two possible exceptions are minor zircon growth during the breakdown

547 of Zr-rich epidote and/or rutile. However, at low temperatures, rutile is not expected to be

548 zirconium rich.

549 The stable mineral assemblage at the metamorphic peak of $660^{\circ} \mathrm{C}$ and $8 \mathrm{kbar}$ includes

550 garnet, staurolite, biotite, plagioclase, ilmenite, muscovite and quartz. In general, the mode of

551 monazite in metapelites is expected to reach a maximum at peak $P-T$ and monazite is not

552 expected to grow during cooling (e.g., Spear and Pyle 2010). An additional factor is that

553 monazite is susceptible to dissolution/reprecipitation in the presence of fluids (e.g., Williams et

554 al. 2011). While fluid-mediated dissolution/reprecipitation should not increase the net mode of

555 monazite, it can occur at almost any point along the $P-T$ evolution. Therefore, it is possible that

556 monazite in a subsolidus metapelite can record a range of ages that vary from monazite-in up to

557 the metamorphic peak and dissolution/precipitation may result in ages that record retrogression

558 (Harlov et al. 2005; Williams et al. 2011). On the other hand, zircon is expected to be relatively

559 unreactive and may not record prograde to peak metamorphism in subsolidus metamorphic

560 rocks. 
After the exhaustion of rutile during the heating and burial segment the value of $a_{\mathrm{TiO} 2}$ decreases to 0.95 initially and remains nearly constant until the decompression and heating

563 segment, where $a_{\mathrm{TiO} 2}$ drops to 0.8 . During the subsequent decompression and cooling segment 564 the $a_{\mathrm{TiO} 2}$ value remains stable at 0.8 . After rutile is exhausted, any growth of new zircon or 565 modification of existing zircon will occur when $a_{\mathrm{TiO} 2}<1.0$; this needs to be considered when 566 applying the Ti-in-zircon thermometer.

Reaction sequence for the hairpin P-T path. A mode-box for the reaction sequence for

569 the hairpin $P-T$ path is shown in Figure $4 \mathrm{~b}$. The prograde reaction sequence includes garnet-in at $570520^{\circ} \mathrm{C}$ and $4.5 \mathrm{kbar}$, staurolite-in at $590^{\circ} \mathrm{C}$ and $6.5 \mathrm{kbar}$ and sillimanite-in at $640^{\circ} \mathrm{C}$ and $6 \mathrm{kbar}$.

571 Garnet both grows and is consumed during the prograde portion of the reaction sequence. The 572 value of $a_{\mathrm{TiO} 2}$ decreases from 0.88 at $500^{\circ} \mathrm{C}$ to 0.79 at peak $T$. For the decompression and cooling 573 segment, a small amount of biotite grows at the expense of garnet; the modes of the other 574 minerals are little changed and the $a_{\mathrm{TiO} 2}$ value remains close to 0.79 .

As with the clockwise $P-T$ path, monazite growth may occur at various times during the 576 prograde segment of the hairpin $P-T$ path. Because the mode of garnet increases and decreases 577 multiple times during the prograde reaction sequence, linking Y and HREE in monazite would 578 be challenging in the absence of microstructural context, such as monazite in coronae 579 surrounding resorbed garnet. For example, HREE and Y-rich monazite could be generated 580 during: (1) the heating and burial segment during garnet breakdown to staurolite, (2) the heating 581 and decompression segment during garnet breakdown to biotite near the metamorphic peak, or 582 (3) garnet breakdown during the retrograde segment of the $P-T$ path. Furthermore, xenotime 583 breakdown during prograde metamorphism would also contribute to the growth of Y and HREE- 
584 rich monazite with or without a contribution from garnet (e.g., Spear and Pyle 2010). Therefore, 585 for the hairpin $P-T$ path modelled here, HREE- or Y-rich monazite can record burial and/or 586 exhumation.

\section{Greywacke}

Phase relations. The pseudosection for the greywacke is shown in Figure 5. Garnet is stable across the entire diagram. Titanite is stable at $T<460-470^{\circ} \mathrm{C}$ with increasing pressure.

591 Biotite is stable across the diagram except at the high- $P-$ low- $T$ corner. Chlorite is unstable above $600^{\circ} \mathrm{C}$ at $7 \mathrm{kbar}$ and unstable above $530^{\circ} \mathrm{C}$ at $12 \mathrm{kbar}$. Albite is stable below $565^{\circ} \mathrm{C}$ at $4 \mathrm{kbar}$ and 593 below $620^{\circ} \mathrm{C}$ at $11 \mathrm{kbar}$. White mica (muscovite and/or paragonite) is stable up to the solidus at $594 P>10 \mathrm{kbar}$ and at $T<570^{\circ} \mathrm{C}$ at $4 \mathrm{kbar}$. There are two important sets of quasi-linear field 595 boundaries with positive slopes in $P-T$ space. First is the set of boundaries that range from $596480^{\circ} \mathrm{C}$ at $4 \mathrm{kbar}$ up to $640^{\circ} \mathrm{C}$ at $12 \mathrm{kbar}$ represent the breakdown of epidote to produce 597 plagioclase. A second set of fields extends from $570^{\circ} \mathrm{C}$ at 4 kbar to the solidus with increasing $P$ 598 that represent the consumption of paragonite to produce sillimanite or kyanite.

601 sequence for the clockwise $P-T$ path is shown in Figure 6a. For the clockwise $P-T$ path the 602 important changes along the prograde reaction sequence include: (1) the growth of rutile 603 commencing at $460^{\circ} \mathrm{C}$ resulting in $a_{\mathrm{TiO} 2}$ increasing from 0.9 at $450^{\circ} \mathrm{C}$ to 1.0 at $460^{\circ} \mathrm{C}$, (2) the 604 complete consumption of titanite by $475^{\circ} \mathrm{C}$, (3) the growth of biotite and garnet at the expense of 605 chlorite and muscovite from $450^{\circ} \mathrm{C}$ to $550^{\circ} \mathrm{C}$, which results in the complete consumption of 606 chlorite by $550^{\circ} \mathrm{C}$, (4) the breakdown of epidote to produce $2 \mathrm{~mol} \%$ plagioclase at $\sim 605^{\circ} \mathrm{C},(5)$ 
607 the consumption of $\sim 0.5 \mathrm{~mol} \%$ garnet to produce plagioclase and hematite from $605^{\circ} \mathrm{C}$ to $620^{\circ} \mathrm{C}$, 608 and (6) the growth of $0.5 \mathrm{~mol} \%$ garnet from $620^{\circ} \mathrm{C}$ to $650^{\circ} \mathrm{C}$. Similar to the metapelite, the 609 breakdown of Zr-rich epidote may result in minor zircon growth.

610 Decompression and heating from $10 \mathrm{kbar}$ at $650^{\circ} \mathrm{C}$ to $8 \mathrm{kbar}$ at $660^{\circ} \mathrm{C}$ results in: (1) the 611 disappearance of rutile at $9.8 \mathrm{kbar}$ and a subsequent drop in $a_{\mathrm{TiO} 2}$, and (2) the breakdown of 612 paragonite and garnet to produce kyanite, biotite and plagioclase at $8.8 \mathrm{kbar}$. The peak 613 metamorphic assemblage at $660^{\circ} \mathrm{C}$ and $8 \mathrm{kbar}$ includes garnet, kyanite, muscovite, biotite, 614 plagioclase and ilmenite. Further decompression and cooling results in the growth of biotite at 615 the expense of garnet and a gradual decrease in $a_{\mathrm{TiO} 2}$.

616 Like the metapelite, garnet breakdown occurs during a portion of the heating and burial 617 segment of the $P-T$ path $\left(\right.$ at $\sim 600^{\circ} \mathrm{C}$ ) and during the heating and decompression segment 618 immediately before the metamorphic peak. Therefore, Y- and HREE-rich monazite associated 619 with garnet breakdown could record the timing of burial and/or exhumation.

Reaction sequence for the hairpin P-T path. A mode-box for the reaction sequence for

622 the hairpin $P-T$ path is shown in Figure $6 \mathrm{~b}$. The hairpin $P-T$ path has three notable differences in 623 its reaction sequence compared with the clockwise path for the greywacke. First, the $P-T$ path 624 does not intersect the epidote stability field. Second, the value of $a_{\mathrm{TiO} 2}$ is always less than one 625 and decreases from 0.95 to 0.80 along the $P-T$ path. And third, white mica is completely 626 consumed by the end of the $P-T$ path. In contrast to the multiple garnet growth/consumption 627 segments along the clockwise $P-T$ path, the mode of garnet increases during burial and decreases 628 during decompression for the hairpin path. Therefore, Y- and HREE-depleted monazite is 
629

630

predicted to record burial and monazite enriched in these elements would document garnetbreakdown during decompression and/or cooling and may also record xenotime breakdown.

\section{SUPRASOLIDUS PHASE RELATIONS AND REACTION SEQUENCES}

Phase relations and reaction sequences for three suprasolidus scenarios are discussed below for a closed system where bulk composition does not change and the water content is fixed to just saturate the rock in $\mathrm{H}_{2} \mathrm{O}$ at $8 \mathrm{kbar}$ at the solidus. This approach provides important first-order constraints on the reaction sequences for the modelled compositions; it does not take into account melt loss and the associated effects on rock fertility, solidus temperature and zircon and monazite stability. The consequences of open system behaviour on the reaction sequence and accessory mineral stability are discussed later.

\section{Metapelite}

Phase Relations. The pseudosection for the metapelite is shown in Figure 7. Ilmenite and plagioclase are stable across the entire diagram. Garnet is stable at high pressures across the diagram except at $T<700^{\circ} \mathrm{C}$ at $P<5.5$ kbar. Cordierite is stable at high- $T$-low- $P$ conditions. Orthopyroxene is not stable in this diagram. Rutile is restricted to $P>10-11.5 \mathrm{kbar}$ across the modelled temperature range. The three important partial melting reactions for the metapelite include: (1) the consumption of any free aqueous fluid to produce melt at the wet solidus, which ranges from $660^{\circ} \mathrm{C}$ at low pressures to $710^{\circ} \mathrm{C}$ at high pressure, (2) the incongruent breakdown of muscovite to produce $\mathrm{K}$-feldspar, which is represented by a narrow low-variance field that extends from the wet solidus at low $P$ to $T>780^{\circ} \mathrm{C}$ at $P>12 \mathrm{kbar}$, and (3) the progressive breakdown of biotite at temperatures above the muscovite stability field to produce either garnet 
652 at higher pressure or cordierite \pm garnet at lower pressure. Biotite is exhausted by $850^{\circ} \mathrm{C}$ at $P>7$

653 kbar and melting progresses via the consumption of quartz and feldspar.

Reaction sequence for the clockwise $\boldsymbol{P}-\boldsymbol{T}$ path. The mode-box and titania activity for the

657 zircon remaining as well as melt ASI are shown in Figure 8b. During the prograde segment of 658 the clockwise $P-T$ path, the metapelite begins to melt at the wet solidus at $\sim 680^{\circ} \mathrm{C}$ through the 659 consumption of any free $\mathrm{H}_{2} \mathrm{O}$ as well as quartz and plagioclase. The amount of aqueous fluid at 660 the solidus is expected to be small given the limited porosity of high-grade metamorphic rocks 661 (e.g., Yardley and Valley 1997). Therefore, the amount of melt produced at the wet solidus is 662 expected to be limited. For the modelled metapelite, the amount of melt produced is $4 \mathrm{~mol} \%$, 663 although this is mostly an artefact of the modelling which assumes $\mathrm{H}_{2} \mathrm{O}$ saturation of the solidus 664 at 8 kbar.

After any free $\mathrm{H}_{2} \mathrm{O}$ is consumed, partial melting continues with increasing temperature 666 through the consumption of muscovite up until $728^{\circ} \mathrm{C}$. This produces an additional 3 mol\% melt 667 with a generally constant melt ASI. At $728^{\circ} \mathrm{C}$ and $7.5 \mathrm{kbar}$, melting proceeds via the incongruent 668 breakdown of muscovite to generate $\mathrm{K}$-feldspar over a narrow $\left(\sim 2^{\circ} \mathrm{C}\right)$ temperature range. This 669 narrow field produces an additional $3 \mathrm{~mol} \%$ melt. After muscovite is exhausted, the rock 670 contains $\sim 9 \mathrm{~mol} \%$ melt and approximately $8 \%$ of the zircon and $12 \%$ of the monazite that was

671 present at the solidus is predicted to have been consumed. A minor amount of apatite breakdown 672 is expected in order to saturate the anatectic melt in phosphorus.

673 After muscovite is completely consumed, partial melting continues through the 674 consumption of biotite, plagioclase and quartz to produce melt, garnet, K-feldspar and ilmenite. 
675 This produces an additional $32 \mathrm{~mol} \%$ melt. Because biotite is an important host of accessory 676 mineral inclusions (e.g., Watson et al. 1989), biotite breakdown may release inclusions of 677 monazite and zircon into the reaction volume of the rock. The liberation of these accessory 678 minerals may contribute to LREE and Zr saturation of the anatectic melt. On the other hand, 679 some zircon and monazite may be included in growing garnet and will be sequestered away from 680 the reaction volume. These minerals will be shielded from dissolution and are more likely to 681 preserve inherited (or detrital) ages as well as any subsolidus to early suprasolidus prograde 682 metamorphic ages. The inclusion of accessory minerals in major minerals effectively reduces the $683 \mathrm{Zr}$ and LREE available to the system and proportionally more zircon and monazite dissolution 684 will be required to maintain melt saturation in these elements (e.g., Yakymchuk and Brown 685 2014b). Therefore, the sequestration of zircon and monazite in stable peritectic minerals such as 686 garnet will promote the dissolution of accessory minerals along grain boundaries in the matrix of 687 the rock with increasing $T$. Titania activity is predicted to reach its highest value of 0.92 at $850^{\circ} \mathrm{C}$. At this point, all 689 of the monazite and $85 \%$ of the zircon are expected to be consumed. However, during this 690 interval, the ASI of the melt increases from 1.10 to 1.15, which may result in enhanced apatite 691 dissolution. For example, Pichavant et al. (1992) estimate that a similar increase in ASI at $800^{\circ} \mathrm{C}$ 692 and 5 kbar would change the $\mathrm{P}_{2} \mathrm{O}_{5}$ concentration of melt from 0.50 to $0.75 \mathrm{wt} \%$. If apatite is 693 LREE rich, the dissolution of apatite may delay the complete dissolution of monazite to higher 694 temperatures or, in extreme cases, may even promote prograde monazite crystallization (e.g., 695 Johnson et al. 2015).

696 After the complete consumption of biotite, the hydrous minerals have been exhausted and 697 the residuum is essentially composed of anhydrous minerals. Melting continues through the 
698 continued consumption of quartz and K-feldspar up to the modelled peak temperature of $900^{\circ} \mathrm{C}$.

699 The ASI of the melt reaches 1.18 at peak $T$ and significant apatite dissolution is likely. At this

700 point, the metapelite contains $43 \mathrm{~mol} \%$ melt and both monazite and zircon are absent. After

701 zircon and monazite are completely consumed, further anatexis is expected to generate melt that

702 is undersaturated in $\mathrm{Zr}$ and LREE. Therefore, even with the breakdown of LREE-rich apatite,

703 prograde monazite crystallization is not expected above $\sim 850^{\circ} \mathrm{C}$.

704 Isothermal decompression from 9 to $7 \mathrm{kbar}$ produces an additional $11 \mathrm{~mol} \%$ melt at the

705 expense of quartz and K-feldspar. At this point the rock contains the maximum amount of melt

706 of $54 \mathrm{~mol} \%$. During this decompression segment, melt ASI increases from 1.18 to 1.23 and $a_{\mathrm{TiO} 2}$

707 decreases from 0.86 to 0.74 . Approximately $1 \mathrm{~mol} \%$ garnet is consumed during decompression,

708 which would liberate some HREE and Y into the reaction volume. If significant apatite

709 dissolution occurs and promotes monazite crystallization during decompression, this may be

710 reflected as elevated HREE concentrations in monazite. However, the melt is undersaturated in

711 LREE given the complete exhaustion of monazite at $850^{\circ} \mathrm{C}$ so new monazite growth is unlikely

712 unless the apatite is very enriched in LREE or the modal proportion of apatite is high.

713 Decompression and cooling from peak $T$ results in: (1) melt crystallization, (2) the

714 growth of K-feldspar and quartz until the cordierite stability field is reached at $\sim 880^{\circ} \mathrm{C}$ and 6.7

715 kbar, (3) garnet and cordierite consumption to produce biotite, (4) new zircon and monazite

716 growth, (5) a decrease in melt ASI and $a_{\mathrm{TiO} 2}$. Melt crystallization and cordierite growth are

717 concomitant with the consumption of garnet and sillimanite; this is a common reaction sequence

718 for high-temperature decompression in migmatites. Zircon or monazite produced over this

719 reaction interval is expected to be enriched in HREE and Y (e.g., Yakymchuk et al. 2015).

720 Protracted monazite and zircon growth will occur from peak $T$ to the solidus. U-Pb zircon and 
721 monazite ages that spread down Concordia have been interpreted to record protracted growth

722 during cooling and melt crystallization in various migmatite terranes with clockwise $P-T$

723 evolutions (Korhonen et al. 2012; Reno et al. 2012; Morrisey et al. 2014; Walsh et al. 2015).

724

725

726

727

728

729

730

731

732

733

734

735

736

737

738

739

740

741

742

Reaction sequence for the counterclockwise $\boldsymbol{P}-\boldsymbol{T}$ path. The mode-box and titania activity for the counterclockwise assemblage sequence are shown in Figure 8c. The amount of monazite and zircon remaining as well as melt ASI are shown in Figure 8d. During isobaric heating at $5 \mathrm{kbar}$, partial melting begins at the wet solidus at $\sim 670^{\circ} \mathrm{C}$ and continues through the breakdown of muscovite to produce a total $8 \mathrm{~mol} \%$ melt by $685^{\circ} \mathrm{C}$. Melting continues via the progressive breakdown of biotite to produce peritectic garnet and $\mathrm{K}$-feldspar. By $765^{\circ} \mathrm{C}, 17$ mol\% melt is present and roughly $80 \%$ and $60 \%$ of the initial amount of zircon and monazite, respectively, remains. From the solidus up to $765^{\circ} \mathrm{C}$, the $a_{\mathrm{TiO} 2}$ value of the system has decreased from 0.9 to 0.6 and the ASI of the melt has increased from 1.13 to 1.18. An increase in melt ASI increases the solubility of apatite; this may liberate some LREE and P that could contribute to minor monazite crystallization because the melt is predicted to be saturated with respect to the LREE. Similar to the clockwise $P-T$ path, the breakdown of biotite may liberate zircon and/or monazite that was sequestered away from the reacting volume.

Cordierite enters the phase assemblage at $\sim 770^{\circ} \mathrm{C}$ and melting continues through the breakdown of biotite, sillimanite and plagioclase to produce K-feldspar, garnet and cordierite. Sillimanite is completely consumed by $780^{\circ} \mathrm{C}$ and biotite is exhausted by $800^{\circ} \mathrm{C}$. During the interval from $770^{\circ} \mathrm{C}$ to $800^{\circ} \mathrm{C}$, approximately $15 \mathrm{~mol} \%$ melt is generated and melt ASI decreases slightly from 1.18 to 1.16 . Although the change in ASI would decrease the solubility of apatite, 
743 this may be counteracted by the additional melt generation during biotite breakdown and apatite 744 growth is not expected.

In the absence of biotite, melting continues through the breakdown of quartz, plagioclase and K-feldspar, which results in a progressively drier melt. Monazite and zircon are predicted to

747 be completely consumed by $820^{\circ} \mathrm{C}$ and $850^{\circ} \mathrm{C}$, respectively. The increase in pressure near the

748 metamorphic peak results in minor cordierite consumption to produce garnet. At the

749 metamorphic peak, the metapelite has generated $\sim 4$ mol\% melt.

Isobaric cooling at $6.5 \mathrm{kbar}$ from $860^{\circ} \mathrm{C}$ to $750^{\circ} \mathrm{C}$ results in: (1) melt crystallization; (2)

751 new zircon and monazite growth commencing at $855^{\circ} \mathrm{C}$ and $825^{\circ} \mathrm{C}$, respectively; (3) a decrease

752 in melt ASI, which would decrease the solubility of apatite and contribute to apatite

753 crystallization; (4) the retrogression of cordierite and garnet to biotite; (5) the consumption of K-

754 feldspar and the growth of plagioclase; and (6) a decrease in $a_{\mathrm{TiO} 2}$. The concurrent breakdown of

755 garnet and growth of zircon, monazite and plagioclase may result in elevated HREE and Y

756 concentrations and more pronounced negative Eu anomalies in newly crystallized accessory

757 minerals. New zircon growth occurs when the $a_{\mathrm{TiO} 2}$ value of the system ranges from 0.6 to 0.7 .

758 Applying the Ti-in-zircon thermometer assuming an $a_{\mathrm{TiO} 2}$ value of 1.0 would underestimate the

759 true temperature by $\sim 50^{\circ} \mathrm{C}$ (Fig. 1b). Protracted retrograde monazite and zircon growth is

760 expected during melt crystallization along the isobaric cooling segment of the counterclockwise

$761 \quad P-T$ path (e.g., Korhonen et al. 2013b)

762

763 Greywacke

Phase relations. The pseudosection for the greywacke is shown in Figure 9. When

765 compared with the metapelite, the greywacke composition is less fertile (e.g., Clemens and 
Vielzeuf 1987; Thompson 1996; Vielzeuf and Schmidt 2001; Johnson et al. 2008; Yakymchuk and Brown 2014a), contains different mineral assemblages, and yields different reaction sequences. For the greywacke, quartz, ilmenite, plagioclase and garnet are stable across the entire diagram. Cordierite becomes stable at pressures of 5-7 kbar with increasing temperature. Orthopyroxene is stable at $P<6 \mathrm{kbar}$ and $T>800^{\circ} \mathrm{C}$. Rutile is stable at $P>9-11 \mathrm{kbar}$.

771 Muscovite is stable at $P>7-12 \mathrm{kbar}$ with increasing temperature. Similar to the metapelite, 772 partial melting of the greywacke begins at the wet solidus at temperatures of $\sim 670-700^{\circ} \mathrm{C}$. A

773 narrow low-variance field representing the breakdown of muscovite to produce K-feldspar is restricted to $P>10.8 \mathrm{kbar}$; this contrasts with a similar field in the metapelite pseudosection that extends from $<4$ to $>12$ kbar (Fig. 7). For the greywacke composition, biotite breakdown generates garnet at high pressure, cordierite at low pressure, and orthopyroxene at low pressure 777 and high temperature.

Reaction sequence for the clockwise $\boldsymbol{P}-\boldsymbol{T}$ path. The mode-box and titania activity for the clockwise assemblage sequence are shown in Figure 10a. The predicted amount of monazite and zircon remaining along with the ASI of melt are shown in Figure 10b. Along the clockwise $P-T$

782 path, partial melting begins at $\sim 675^{\circ} \mathrm{C}$ at the wet solidus and muscovite is not stable. Therefore,

783 further melting proceeds through the breakdown of biotite and sillimanite to produce garnet.

784 Similar to the metapelite, growing garnet has the potential to capture inherited or prograde 785 monazite and zircon allowing their preservation to higher temperatures. K-feldspar becomes stable at $800^{\circ} \mathrm{C}$ and $8.2 \mathrm{kbar}$ and biotite is completely consumed by $850^{\circ} \mathrm{C}$. Up to this point, the

787 greywacke has produced $14 \mathrm{~mol} \%$ melt, which is less than the $34 \mathrm{~mol} \%$ melt generated by the 788 pelite for the same $P-T$ path. Up to $850^{\circ} \mathrm{C}$, melt is produced gradually for the greywacke 
composition whereas melting of the metapelite occurs as a pulse in the narrow muscovite-Kfeldspar field followed by more gradual melting due to biotite breakdown.

Beyond the loss of biotite from the stable assemblage, melting continues through the

792 breakdown of $\mathrm{K}$-feldspar, plagioclase and quartz and an additional $4 \mathrm{~mol} \%$ melt is produced by

$793900^{\circ} \mathrm{C}$. Although monazite dissolution is modelled to continue from 850 to $900^{\circ} \mathrm{C}$, some

794 prograde monazite crystallization may be possible in this temperature range for three reasons.

795 First, the melt is saturated with respect to LREE due to progressive monazite dissolution.

796 Second, after the exhaustion of biotite the melt becomes progressively drier, which decreases the 797 solubility of monazite. Third, melt ASI increases, which increases the dissolution of apatite and 798 may liberate enough LREE to support new monazite growth. However, unless this monazite is 799 sequestered away in a growing peritectic mineral (such as garnet) it is expected to be consumed 800 during further heating and partial melting.

$801 \quad$ All of the monazite and $\sim 65 \%$ of the zircon are consumed by $900^{\circ} \mathrm{C}$. Isothermal 802 decompression from 9 kbar to 7 kbar produces an additional 4 mol\% melt and results in minor 803 ( $<1 \mathrm{~mol} \%)$ garnet consumption. Melt ASI increases from 1.18 to 1.23 during decompression, 804 which enhances the solubility of apatite. However, the melt is undersaturated with respect to 805 LREE and new monazite growth is not expected during decompression. Approximately $10 \%$ of 806 the initial amount of zircon present at the solidus is consumed during decompression and titania 807 activity decreases from 0.95 to 0.85 .

808 Cooling and decompression from peak $T$ to $750^{\circ} \mathrm{C}$ results in: (1) melt crystallization, (2) 809 the consumption of garnet and sillimanite to produce cordierite commencing at $890^{\circ} \mathrm{C}$ and biotite 810 starting at $840^{\circ} \mathrm{C},(3)$ a decrease in $a_{\mathrm{TiO} 2}$ from 0.85 to 0.65 , (4) a decrease in melt ASI from 1.23 811 to 1.16 , (5) the growth of new zircon (likely as overgrowths on existing zircon), and (6) the 
812 crystallization of monazite starting at $\sim 885^{\circ} \mathrm{C}$. Zircon and monazite growth occurs during garnet

813 breakdown and these accessory minerals are expected to have elevated Y and HREE

814 concentrations. The application of Ti-in-zircon thermometry should use an $a_{\mathrm{TiO} 2}$ value ranging

815 from 0.85 to 0.65 . Assuming a $a_{\mathrm{TiO} 2}$ value of 1.0 would underestimate temperatures by up to $81650^{\circ} \mathrm{C}$ (Fig. 1b).

817

Reaction sequence for the counterclockwise $P-T$ path. The mode-box and titania

819 activity for the counterclockwise assemblage sequence are shown in Figure 10c. The amount of 820 monazite and zircon remaining as well as melt ASI are shown in Figure 10d. Similar to the 821 clockwise $P-T$ path for the greywacke, the prograde segment of the counterclockwise $P-T$ path 822 generates melt gradually in contrast to the more pulsed melting in the metapelite. Melting 823 commences at the wet solidus and proceeds via the breakdown of biotite to produce cordierite 824 and garnet followed by $\mathrm{K}$-feldspar at $760^{\circ} \mathrm{C}$. Orthopyroxene enters the phase assemblage at $825825^{\circ} \mathrm{C}$ and biotite is completely consumed by $830^{\circ} \mathrm{C}$. The value of $a_{\mathrm{TiO} 2}$ decreases from $\sim 0.80$ to 8260.60 up to the orthopyroxene-in field boundary and then increases for the remainder of the 827 prograde path. The increase in pressure near peak $T$ results in the breakdown of orthopyroxene to 828 produce garnet (e.g., White et al. 2008). By the end of the heating segment, $\sim 50 \%$ of the zircon 829 and $\sim 70 \%$ of the monazite that was present at the solidus has been consumed. Melt ASI varies 830 between 1.16 and 1.11 during the prograde path. As with the clockwise $P-T$ path, melting above 831 the biotite-stability field (in this case from $830-860^{\circ} \mathrm{C}$ ) has the potential to generate some 832 prograde monazite if LREE-rich apatite is consumed. A total of $18 \mathrm{~mol} \%$ melt is predicted to be 833 generated during heating, which is significantly less than the $44 \mathrm{~mol} \%$ produced along the same $834 P-T$ path for the metapelite. 
Consistent with the metapelite for the same $P-T$ path, isobaric cooling results in melt crystallization and monazite and zircon growth. The mode of garnet decreases by $7 \mathrm{~mol} \%$ and $\mathrm{K}$ -

837 feldspar breaks down to sillimanite in the presence of melt at $815^{\circ} \mathrm{C}$. Zircon and monazite 838 crystallization is predicted to have elevated Y and HREE due to the breakdown of garnet. Zircon 839 growth occurs when the $a_{\mathrm{TiO} 2}$ value of the system is $\sim 0.7$.

\section{Average Mid Ocean Ridge Basalt}

Phase relations. The $P-T$ pseudosection for an average MORB composition is shown in

843 Figure 11. The wet solidus has a negative slope from 4 to $11.5 \mathrm{kbar}$ and a positive slope at $T$

$844>11.5 \mathrm{kbar}$. The temperature of the wet solidus ranges from 620 to $700^{\circ} \mathrm{C}$ over the modelled $P-T$ 845 range. Garnet is stable from 10-14 kbar with decreasing temperature. Orthopyroxene enters the 846 assemblage at temperatures of $800^{\circ} \mathrm{C}$ to $900^{\circ} \mathrm{C}$ with increasing $P$ and is not stable above $10 \mathrm{kbar}$

847 at high $T$. Garnet and orthopyroxene are only stable together at pressures of 9.5-10 kbar and at $T$ $848>900^{\circ} \mathrm{C}$. Rutile is stable at $T>790^{\circ} \mathrm{C}$ at $P>7 \mathrm{kbar}$.

Reaction sequence for the clockwise $\boldsymbol{P}-\boldsymbol{T}$ path. The mode-box and titania activity for the reaction sequence as well as the amount of zircon remaining and melt ASI are shown in Figure

852 12. Melting starts at the wet solidus at $630^{\circ} \mathrm{C}$ and $9.7 \mathrm{kbar}$ and generates $\sim 2 \mathrm{~mol} \%$ melt and $\sim 2$

853 mol\% clinopyroxene at the expense of epidote and biotite. A minor amount ( 2 mol\%) of zircon

854 is expected to be consumed in order to saturate the melt in Zr. Epidote can be an important 855 source of Zr (e.g., Kohn et al. 2015) and the breakdown of Zr-rich epidote may result in Zr 856 saturation and minor zircon crystallization at this stage. After the exhaustion of biotite at $857 \sim 650^{\circ} \mathrm{C}$, melting continues via the breakdown of hornblende, titanite and quartz to produce an 
858

859

860

861

862

863

864

865

866

867

868

869

870

871

872

873

874

875

876

877

878

879

880

additional 4 mol\% melt as well as peritectic clinopyroxene by $800^{\circ} \mathrm{C}$ and $11.4 \mathrm{kbar}$. During this portion of the prograde path, $a_{\mathrm{TiO} 2}$ increases from 0.6 at the wet solidus up to 0.9 at $800^{\circ} \mathrm{C}$. The amount of zircon remaining is $\sim 80 \mathrm{~mol} \%$ of the amount present at the solidus. Melt ASI increases slightly from 0.99 to 1.00 .

Garnet becomes stable at $\sim 800^{\circ} \mathrm{C}$ and melting proceeds through the breakdown of hornblende and titanite. Garnet growth may include zircon grains that would be isolated from the reacting volume of the rock and zircon could be preserved to higher $T$. Rutile becomes stable at $818^{\circ} \mathrm{C}$ and titanite is completely consumed by $821^{\circ} \mathrm{C}$. The peak pressure of $12 \mathrm{kbar}$ is reached at $850^{\circ} \mathrm{C}$ and at this point the system contains $\sim 13 \mathrm{~mol} \%$ melt, $10 \mathrm{~mol} \%$ garnet and $65 \%$ of the zircon has been consumed. Although zircon is expected to be consumed during partial melting, the breakdown of Zr-rich amphibole (e.g., Sláma et al. 2007) may yield enough Zr to oversaturate the melt and grow new zircon; this zircon may be relatively depleted in HREE in response to the presence of garnet in the rock.

The isobaric heating segment of the $P-T$ path at peak $P$ produces garnet at the expense of hornblende and quartz. Quartz is exhausted at $905^{\circ} \mathrm{C}$. This has implications for applying the Tiin-zircon thermometer, which uses $a_{\mathrm{SiO} 2}$ as a variable. Zircon is completely consumed by $880^{\circ} \mathrm{C}$ and the melt produced at higher $T$ is expected to be undersaturated in $\mathrm{Zr}$. A consequence of this is that prograde zircon growth at $T>880^{\circ} \mathrm{C}$ is unlikely because any excess $\mathrm{Zr}$ due to the breakdown of other minerals (e.g., amphibole) will be incorporated into the Zr-undersaturated melt. At the metamorphic peak of $950^{\circ} \mathrm{C}$, the system contains $\sim 28 \mathrm{~mol} \% \mathrm{melt}, \sim 20 \mathrm{~mol} \%$ garnet and $\sim 14 \%$ hornblende.

Isothermal decompression from 12 to $10 \mathrm{kbar}$ results in significant garnet consumption (from 20 to 9 mol\%), hornblende growth (from 14 to 24 mol\%) and minor melt consumption 
881 (from 28 to $27 \mathrm{~mol} \%$ ). Zirconium liberated from garnet breakdown is expected to be partitioned

882 between the Zr-undersaturated melt and hornblende. Consequently, zircon crystallization is

883 unlikely. Orthopyroxene enters the assemblage at $10.1 \mathrm{kbar}$ and grows at the expense of garnet,

884 which is exhausted by 9.7 kbar. If garnet is completely consumed, any liberated zircon may

885 become available to the reacting volume and will likely be consumed into the Zr-undersaturated

886 melt. Rutile is completely consumed by $9.1 \mathrm{kbar}$ and $a_{\mathrm{TiO} 2}$ decreases with further decompression.

887 At the end of the isothermal decompression segment of the $P-T$ path the amount of

888 orthopyroxene reaches $5 \mathrm{~mol} \%$. No new zircon growth is expected during the isothermal

889 decompression segment because: (1) there is a $<1 \mathrm{~mol} \%$ melt change during isothermal

890 decompression and the melt is already significantly undersaturated in $\mathrm{Zr}$, (2) the $M$ value of the

891 melt (cation ratio of $[\mathrm{Na}+\mathrm{K}+2 \mathrm{Ca}] /[\mathrm{Al} x \mathrm{Si}]$ ) increases from 1.6 to 1.7 , which results in an

892 increases the $\mathrm{Zr}$ required to saturate the melt (Harrison and Watson 1983; Boehnke et al. 2013),

893 (3) the mode of hornblende increases from 14 to 23 mol\%, likely accommodating significant

894 amounts of Zr at high temperature (e.g., Kohn et al. 2015).

895 Cooling and decompression from $950^{\circ} \mathrm{C}$ at $8 \mathrm{kbar}$ to $800^{\circ} \mathrm{C}$ at $6 \mathrm{kbar}$ results in the

896 consumption of $17 \mathrm{~mol} \%$ melt and the complete breakdown of orthopyroxene by $\sim 830^{\circ} \mathrm{C}$.

897 Zirconium saturation of the melt is reached at $\sim 870^{\circ} \mathrm{C}$ and zircon begins to crystallize. At

$898 \sim 850^{\circ} \mathrm{C}$, approximately $20 \%$ of the amount of zircon originally present at the solidus has grown

899 back and this zircon expected to be enriched in HREE because there is no garnet present in the

900 system. Zircon growth at this stage occurs in a system with an $a_{\mathrm{TiO} 2}$ value of 0.9 and in the

901 absence of quartz, which is important for the application of Ti-in-zircon thermometry.

902

903 Summary of reaction sequence modelling 
Linking the trace element concentrations of accessory minerals to the key major minerals

905 (e.g., garnet and plagioclase) requires an understanding of the reaction sequences for a particular

906 bulk composition. Key minerals like garnet and plagioclase can grow or be consumed multiple

907 times along a $P-T$ path during heating and cooling or burial and exhumation (Figs 3-10). For

908 example, garnet is predicted to grow in the subsolidus greywacke composition during heating

909 and burial and garnet breakdown occurs during cooling and exhumation for the hairpin $P-T$ path

910 (Fig. 6b). By contrast, garnet growth and consumption occurs multiple times along the heating

911 and increasing pressure segment of the $P-T$ paths for the subsolidus metapelite composition (Fig.

912 4). Therefore, high-Y and high-HREE zones in monazite that can be linked to garnet breakdown

913 may reflect the burial and/or exhumation portions of a $P-T$ path.

914 Titania activity also varies along the modelled $P-T$ paths and this needs to be taken into

915 account when applying Ti-in-zircon or Ti-in-quartz thermometers. In general, new zircon growth

916 in subsolidus rocks is expected to be limited because major minerals such as hornblende and

917 garnet can accommodate more $\mathrm{Zr}$ with increasing temperature. One exception to this may be

918 minor zircon growth through the breakdown of Zr-rich epidote. For the suprasolidus $P-T$ paths

919 for the metapelite and greywacke, new zircon growth is expected during cooling and melt

920 crystallization; this growth is predicted to occur when bulk rock $a_{\mathrm{TiO} 2}$ is less than one for all of

921 the modelled $P-T$ paths. If the Ti-in-zircon thermometer is applied with an $a_{\mathrm{TiO} 2}$ value of one,

922 then the result will be an underestimation in peak metamorphic temperatures by up to $\sim 40^{\circ} \mathrm{C}$. For

923 the MORB composition, new zircon growth occurs at $a_{\mathrm{TiO} 2}<1.0$ as cooling and melt

924 crystallization occurs outside the stability field of rutile (Fig. 12).

925 In suprasolidus metamorphic rocks, zircon and monazite are expected to be consumed

926 along the prograde path and new growth is generally predicted to occur along the cooling path. 
927 Zircon and monazite dissolution is non-linear and the rate increases with increasing temperature.

928 For the clockwise $P-T$ path for the metapelite and greywacke, an increase in the melt ASI leads

929 to more apatite dissolution. Because the melt is saturated in LREE with respect to monazite up to

$930820^{\circ} \mathrm{C}$, apatite breakdown may liberate enough LREE to promote new monazite growth.

931 However, after the exhaustion of monazite, the melt is expected to be undersaturated in LREE

932 and prograde monazite growth at the expense of LREE-rich apatite is unlikely. For the

933 counterclockwise $P-T$ path for the metapelite and greywacke, melt ASI increases and decreases

934 during the $P-T$ evolution and monazite growth from apatite breakdown will be more complex to 935 interpret.

936 The metapelite is expected to lose most of the inherited or subsolidus prograde monazite

937 and zircon during heating above the solidus (unless these mineral are sequestered away from the

938 reaction volume) whereas a larger proportion of these minerals remains in the greywacke

939 composition except for the clockwise $P-T$ path where monazite is completely consumed for the

940 greywacke. The difference reflects the fertility of the two rocks; pelites generate more melt than

941 the greywacke and require more $\mathrm{Zr}$ and LREE to saturate this melt. Therefore, less fertile

942 compositions, such as greywackes, are more likely to preserve subsolidus zircon and monazite.

\section{COMPLICATING FACTORS}

945 Changes in effective bulk composition

946 Phase equilibria modelling requires an assessment of the effective bulk composition of a

947 system that is used to model the $P-T$ phase relations for a rock (e.g., Stüwe 1997). The effective

948 bulk composition approximates the composition 'available' to the rock in which equilibrated

949 mineral assemblages and reaction sequence develop. In natural systems, the effective bulk 
950

951

952

953

954

955

956

957

958

959

960

961

962

963

964

965

966

967

968

969

970

971

972

composition may change along a $P-T$ path (e.g., Guevara and Caddick 2016), which has

subsequent implications for modelling reaction sequences in both subsolidus and suprasolidus

metamorphic rocks. There are two main mechanisms that can change the effective bulk

composition of a metamorphic system: fractionation of elements into growing porphyroblasts and melt loss.

Growing porphyroblasts can fractionate certain elements into their cores that become unavailable to the reacting system in the remainder of the rock. For example, chemical zoning in garnet is commonly preserved in metamorphic rocks because cation diffusion in garnet is relatively slow (e.g., Chakraborty and Ganguly 1992). The preferential partitioning of elements into garnet cores reduces their effective composition in the reactive volume of the rock (e.g., Lanari and Engi, 2017). Some of the consequences for using phase diagrams to infer metamorphic conditions considering garnet fractionation include reduced stability fields for garnet (Gaides et al. 2008) and other minerals (Zuluaga et al. 2005; Moynihan and Pattison 2013) as well as changes in mineral compositional isopleths for garnet (Evans 2004; Gaides et al. 2006) and plagioclase (Moynihan and Pattison 2013). While crystal fractionation needs to be assessed on a case-by-case basis, it is generally most important to consider for greenschist- and amphibolite-facies metamorphic assemblages where mineral chemistries are particularity useful for determining $P-T$ conditions. At higher grades, the use of mineral composition isopleths is generally less effective due to retrograde exchange reactions (e.g., Spear and Florence 1992;

Kohn and Spear 2000; Pattison et al. 2003). For zircon, the fractionation of $\mathrm{Zr}$ into growing garnet (e.g., Kohn et al. 2015) may reduce the Zr budget available for zircon growth. In high-grade metamorphic rocks that underwent anatexis the preservation of peritectic minerals and lack of extensive retrogression supports melt drainage during prograde 
973 metamorphism (Fyfe 1973; Powell 1983; White and Powell 2002; Guernina and Sawyer 2003;

974 Reno et al. 2012). Melt loss produces progressively more refractory bulk compositions, which

975 results in elevated solidus temperatures in the residual rocks. In migmatites that have undergone

976 melt loss, suprasolidus zircon and monazite growth is generally expected to occur during cooling

977 from peak $T$ to the elevated solidus (e.g., Kelsey et al. 2008; Spear and Pyle 2010; Yakymchuk

978 and Brown 2014b). Therefore, rocks that have experienced identical $P-T$ histories but variable

979 amounts of melt loss and have different solidus temperatures should record a range of ages (e.g.,

980 Korhonen et al. 2013b).

981

982 Bulk composition and the suprasolidus behaviour of zircon and monazite

983 For the modelled suprasolidus reaction sequences, the preservation of subsolidus (e.g.,

984 prograde or inherited) zircon and monazite is mainly related to the fertility of the rocks. The

985 metapelite generates more melt along the same $P-T$ path than the greywacke. Consequently,

986 zircon and monazite are completely consumed for the metapelite composition along both $P-T$

987 paths (Figs 8a, b) whereas some zircon and/or monazite can survive in the greywacke. An

988 additional factor is the bulk rock content of $\mathrm{Zr}$ for zircon and LREE and phosphorus for monazite

989 (e.g., Kelsey et al. 2008; Yakymchuk and Brown 2014b). Both of these factors are explored

990 together in Figure 13.

991 The temperature-composition diagrams in Figure 13 illustrate the variation in melt mode

992 and the stability of zircon and monazite for compositions ranging linearly from the metapelite

993 (left side) to that of the greywacke (right side). The diagrams are isobaric and were calculated at

$9947 \mathrm{kbar}$ because this pressure intersects the main melt producing reactions for both bulk

995 compositions. The common reaction to both compositions is the breakdown of biotite to produce 
cordierite at $\sim 840-845^{\circ} \mathrm{C}$ (Fig. 13a). The amount of melt in the metapelite composition is roughly twice the amount in the greywacke composition over the range of modelled temperatures (Fig. 13b). For a bulk composition of $150 \mathrm{ppm} \mathrm{Zr,} \mathrm{zircon} \mathrm{is} \mathrm{completely} \mathrm{consumed} \mathrm{in} \mathrm{the}$ metapelite composition by $925^{\circ} \mathrm{C}$ whereas only $30 \%$ of the zircon has been consumed in the greywacke composition at the same temperature (Fig. 13c). For a bulk composition of 150 ppm LREE, monazite is completely consumed by $830^{\circ} \mathrm{C}$ for the metapelite and $880^{\circ} \mathrm{C}$ for the greywacke (Fig. 13d). The slopes of the dissolution contours are steeper for zircon than for monazite in Figures $13 \mathrm{c}$ and 13d. This indicates that zircon dissolution is more sensitive to bulk composition (metapelite vs. greywacke) than monazite.

The sensitivity of zircon and monazite dissolution to bulk composition of $\mathrm{Zr}$ and LREE is explored in Figures 13e and 13f. The contours represent the complete dissolution of zircon and monazite for various bulk rock $\mathrm{Zr}$ and LREE contents. For low-Zr pelites with concentrations of $50 \mathrm{ppm}$, zircon is completely consumed by $860^{\circ} \mathrm{C}$, which is $65^{\circ} \mathrm{C}$ lower than for a closer-toaverage $\mathrm{Zr}$ concentration of $150 \mathrm{ppm}$. Greywackes with low concentrations of $\mathrm{Zr}$ (e.g., $50 \mathrm{ppm}$ ) can still preserve zircon up to UHT conditions due to their lower fertility. Monazite dissolution contours in Figure $13 \mathrm{f}$ have shallower slopes than those for zircon (Fig. 13e), which again suggests that monazite dissolution is less sensitive to bulk composition. A metapelite with low concentrations of LREE (e.g., $50 \mathrm{ppm}$ ) is predicted to lose monazite by $780^{\circ} \mathrm{C}$ and monazite is expected to be completely consumed in the greywacke composition by $820^{\circ} \mathrm{C}$. Preserving subsolidus monazite to UHT conditions requires very LREE-rich compositions of $>400 \mathrm{ppm}$ for the metapelite and $>180 \mathrm{ppm}$ for the greywacke. Therefore, a strategy for finding subsolidus prograde zircon and monazite in migmatites is to choose samples with the highest concentrations of $\mathrm{Zr}$ and LREE. 
1020 suprasolidus monazite growth (e.g., Johnson et al. 2015). This is most likely to occur when the

1021 anatectic melt is saturated with respect to monazite in LREE. After the exhaustion of monazite,

1022 the melt is expected to be undersaturated and LREE liberated from the breakdown of apatite is

1023 not predicted to generate new prograde monazite growth. In principle, the higher the bulk rock

1024 LREE the longer monazite will persist during a suprasolidus heating path and the longer the melt

1025 will remain saturated with respect to LREE (Fig. 13f). A further consideration is that bulk

1026 compositions with low phosphorus concentrations may lose apatite during the prograde path and

1027 would result in melt that is undersaturated in P. This may promote further monazite dissolution

1028 instead of monazite growth. Therefore, LREE and P-rich bulk compositions should be targeted

1029 for accessory mineral geochronology to constrain the timing of suprasolidus prograde monazite 1030 growth.

1032 Effects of open system behaviour on accessory minerals

1033 Dissolution/re-precipitation of accessory minerals in metamorphic rocks due to the 1034 infiltration of an externally derived fluid has been documented in experiments and studies of 1035 natural samples (e.g., Tomaschek et al. 2003; Crowley et al. 2008; Harlov and Hetherington 1036 2010; Blereau et al. 2016). The careful integration of petrography with the chemistries of these 1037 minerals can be used to provide information on the timing of fluid infiltration (e.g., Williams et 1038 al. 2011) and on fluid chemistry (e.g., Harlov et al. 2011; Taylor et al. 2014; Shazia et al. 2015). 1039 However, the timing of fluid ingress relative to the metamorphic history and the chemistry of 1040 these fluids are highly variable and should to be assessed on a case-by-case basis. 
1042 also change the effective composition of the residuum (e.g., Rapp et al. 1987), which has

1043 subsequent consequences for zircon and monazite dissolution. For example, consider the

1044 muscovite to K-feldspar melting reaction for the metapelite along the clockwise $P-T$ path at

$1045 \sim 730^{\circ} \mathrm{C}$ and $7.5 \mathrm{kbar}$ and consider bulk rock values of $150 \mathrm{ppm}$ for LREE and $\mathrm{Zr}$. This reaction

1046 involves a large positive volume change (e.g., Powell et al. 2005), which may be accommodated

1047 by melt extraction from the rock. When muscovite is exhausted the rock contains $\sim 9$ mol\% melt.

1048 The saturation concentrations of LREE and $\mathrm{Zr}$ in the melt at this point are $195 \mathrm{ppm}$ and 137

1049 ppm, respectively. Assuming 8 vol\% melt (approximately equivalent to $8 \mathrm{~mol} \%$ ) is extracted

1050 (leaving $1 \mathrm{vol} \%$ in the rock along grain boundaries), mass balance can be used to determine the

1051 amount of $\mathrm{Zr}$ and LREE left in the system. For this example, the effective concentration of

1052 LREE in the rock decreases to $146 \mathrm{ppm}$ and the effective concentration of $\mathrm{Zr}$ increases to 151

$1053 \mathrm{ppm}$. Although the changes to the bulk composition are minor in this example, monazite is

1054 predicted to be completely consumed at lower $T$ and zircon may persist to higher $T$ than for

1055 closed system (Fig. 13). For rocks with very low concentrations of Zr and LREE, melt extraction

1056 can have a more significant impact on the effective bulk concentrations of these elements and the

1057 stability of zircon and monazite (e.g., Yakymchuk and Brown 2014b).

1058

1059 Inclusion/host relationships

1060 An important consideration for accessory mineral reactivity is their inclusion in the major 1061 rock-forming minerals (Watson et al. 1989; Bea et al. 2006). Watson et al. (1989) showed that

1062 for a Himalayan migmatite sample roughly $78 \%$ of the zircon mass is located along grain

1063 boundaries and the remaining $28 \%$ is included in major minerals (predominately biotite and 
1064 garnet), though how representative this is of typical migmatitic gneiss is unknown.

1065 Consequently, the breakdown of major minerals may liberate accessory minerals into the

1066 reacting volume of the rock that would otherwise be sequestered away.

1067 Inclusions of zircon and monazite that are isolated from the reaction volume may also

1068 reduce the effective bulk rock concentration of $\mathrm{Zr}$ and LREE (Yakymchuk and Brown 2014b).

1069 For example, consider a bulk rock composition of LREE with half of the monazite sequestered

1070 away from the reaction volume as inclusions. For a metapelite with a bulk rock LREE

1071 composition of $300 \mathrm{ppm}$ and considering that half of this is unavailable, the effective

1072 concentration of LREE is $150 \mathrm{ppm}$. The complete dissolution of monazite is modelled to occur at

$1073830^{\circ} \mathrm{C}$ in contrast to $870^{\circ} \mathrm{C}$ for the scenario where all monazite is available for reaction (Fig.

1074 13f). Therefore, applying the models in Figure 13 to natural examples requires an estimate of the

1075 amount of zircon or monazite sequestered away from the reaction volume as inclusions as well

1076 as an estimate of the amount of $\mathrm{Zr}$ and LREE locked away in the major minerals.

1077 The heterogeneous distribution of melt and minerals in high-grade metamorphic rocks

1078 also has implications for the dissolution and preservation of accessory minerals. Even for an

1079 initially homogenous protolith, in situ melt may be spatially associated with peritectic minerals

1080 in isolated patches; this produces a heterogeneous melt framework (e.g., White et al. 2004).

1081 Zircon and monazite proximal to the zones of incipient melting and in chemical communication

1082 with this melt are more likely to contribute to $\mathrm{Zr}$ and LREE saturation of the melt whereas more

1083 distal grains may not. Consequently, detrital, inherited or prograde (subsolidus or early

1084 suprasolidus) zircon and monazite are more likely to be preserved in domains away from

1085 incipient melting whereas post-peak and retrograde zircon and monazite may be spatially

1086 associated with in situ leucosome. 


\section{CONCLUDING REMARKS}

1089 One important facet of petrochronology is to link the ages of accessory mineral

1090 chronometers to the $P-T$ information obtained from major rock-forming minerals in

1091 metamorphic rocks. The growth and consumption of major minerals is important because these

1092 minerals: (1) may contain the necessary essential structural constituents to promote accessory

1093 mineral growth directly from their breakdown, (2) are repositories of the trace elements used to

1094 link accessory mineral chronometers to $P-T$ conditions (e.g., Sr and Eu related to stability of

1095 plagioclase as well as Y and HREE reflecting the growth/consumption of garnet), (3) are

1096 important hosts for accessory mineral inclusions, and (4) play a role in controlling the

1097 component activities (e.g., $a_{\mathrm{TiO} 2}$ ) along a $P-T$ evolution. The main controls on accessory mineral

1098 behaviour differ between subsolidus and suprasolidus metamorphic conditions.

1099 For subsolidus metamorphism, zircon is generally unreactive and monazite can grow

1100 during the prograde and retrograde segments. Linking ages from these accessory mineral to a

1101 metamorphic history requires an understanding of the major mineral reaction sequence as well as

1102 the behaviour of accessory minerals like xenotime, apatite and allanite. Major minerals such as

1103 garnet or plagioclase may experience growth and breakdown stages at any point along a $P-T$

1104 path: linking their behaviour to the trace element chemistries of accessory minerals requires an

1105 assessment of the reaction sequence for a particular rock along a well-constrained $P-T$ path.

1106 For suprasolidus metamorphism, phase equilibria modelling predicts that both zircon and

1107 monazite will be consumed during prograde metamorphism and grow during cooling and melt

1108 crystallization. However, this contrasts with some studies that have convincingly showed

1109 evidence for suprasolidus prograde zircon and monazite growth. For monazite, apatite 
1110 dissolution may have contributed to minor prograde monazite growth if the anatectic melt is

1111 saturated in LREE. For zircon, solid-state breakdown of major minerals that contain appreciable

1112 quantities of $\mathrm{Zr}$ may facilitate prograde zircon growth. Ostwald ripening may also play a role in

1113 the prograde growth of both zircon and monazite, but this mechanism is still incompletely

1114 understood.

\section{Acknowledgements}

1117 We thank Mark Caddick and Dave Waters for thorough and perceptive reviews and Pierre Lanari

1118 for his patient editorial work. Nonetheless, the authors are responsible for any misinterpretations

1119 or omissions that persist. CY was partially funded by a National Sciences and Engineering

1120 Research Council of Canada Discovery Grant.

1121

1122

1123

1124

1125

1126

1127

1128

1129

1130

1131

1132

1133

1134

1135

1136

1137

1138

1139

1140

1141

1142

1143

1144

\section{References}

Ague JJ (1991) Evidence for major mass transfer and volume strain during regional metamorphism of pelites. Geology 19:855-858

Ashley KT, Law RD (2015) Modeling prograde TiO2 activity and its significance for Ti-inquartz thermobarometry of pelitic metamorphic rocks. Contr Mineral and Petrol 169:1-7

Ayers JC, Miller C, Gorisch B, Milleman J (1999) Textural development of monazite during high-grade metamorphism: Hydrothermal growth kinetics, with implications for $\mathrm{U}$, Th$\mathrm{Pb}$ geochronology. Am Mineral 84:1766-1780

Baxter EF, Scherer EE (2013) Garnet geochronology: timekeeper of tectonometamorphic processes. Elements 9:433-438

Baxter EF (2017) Title of Chapter. Rev Mineral Geochem XX:xxx-xxx.

Bea F, Pereira MD, Stroh A (1994) Mineral/leucosome trace-element partitioning in a peraluminous migmatite (a laser ablation-ICP-MS study). Chem Geol 117:291-312

Bea F, Montero P (1999) Behavior of accessory phases and redistribution of Zr, REE, Y, Th, and $\mathrm{U}$ during metamorphism and partial melting of metapelites in the lower crust: an example from the Kinzigite Formation of Ivrea-Verbano, NW Italy. Geochim Cosmochim Acta 63:1133-1153

Bea F, Montero P, Ortega M (2006) A LA-ICP-MS evaluation of Zr reservoirs in common crustal rocks: implications for $\mathrm{Zr}$ and $\mathrm{Hf}$ geochemistry, and zircon-forming processes. Can Mineral 44:693-714

Berman RG (1988) Internally-consistent thermodynamic data for minerals in the system Na2OK2O-CaO-MgO-FeO-Fe2O3-A12O3-SiO2-TiO2-H2O-CO2. J Petrol 29:445-522 
Bingen B, Austrheim H, Whitehouse M (2001) Ilmenite as a source for zirconium during highgrade metamorphism? Textural evidence from the Caledonides of Western Norway and implications for zircon geochronology. J Petrol 42:355-375

Blereau E, Clark C, Taylor RJM, Johnson TJ, Fitzsimons I, Santosh M (2016) Constraints on the timing and conditions of high-grade metamorphism, charnockite formation and fluidrock interaction in the Trivandrum Block, southern India. J Metamorph Geol 34:527-549.

Boehnke P, Watson EB, Trail D, Harrison TM, Schmitt AK (2013) Zircon saturation re-revisited. Chem Geol 351:324-334

Brown M (1998) Unpairing metamorphic belts: P-T paths and a tectonic model for the Ryoke Belt, southwest Japan. J Metamorph Geol 16:3-22

Brown M (2014) The contribution of metamorphic petrology to understanding lithosphere evolution and geodynamics. Geosci Front 5:553-569

Brown M, Kothonen FJ (2009) Some remarks on melting and extreme metamorphism of crustal rocks. In: Physics and Chemistry of the Earth's Interior. Gupta AK and Dasgupta S (eds) Springer, $\mathrm{p}$ 67-87

Caddick MJ, Kohn MJ (2013) Garnet: Witness to the evolution of destructive plate boundaries. Elements 9:427-432

Carlson WD (1999) The case against Ostwald ripening of porphyroblasts. Can Mineral 37:403414

Carlson WD (2000) The case against Ostwald ripening of porphyroblasts: reply. Can Mineral 38:1029-1031

Catlos EJ, Harrison TM, Kohn MJ, Grove M, Ryerson FJ, Manning CE, Upreti BN (2001) Geochronologic and thermobarometric constraints on the evolution of the Main Central Thrust, central Nepal Himalaya. J Geophys Res B: Solid Earth 106:16177-16204

Chakraborty S, Ganguly J (1992) Cation diffusion in aluminosilicate garnets: experimental determination in spessartine-almandine diffusion couples, evaluation of effective binary diffusion coefficients, and applications. Contr Mineral and Petrol 111:74-86

Chambers JA, Kohn MJ (2012) Titanium in muscovite, biotite, and hornblende: Modeling, thermometry, and rutile activities of metapelites and amphibolites. Am Mineral 97:543555

Chen Y-X, Zheng Y-F, Hu Z (2013) Synexhumation anatexis of ultrahigh-pressure metamorphic rocks: petrological evidence from granitic gneiss in the Sulu orogen. Lithos 156:69-96

Clark C, Fitzsimons ICW, Healy D, Harley SL (2011) How does the continental crust get really hot? Elements 7:235-240

Clark C, Kirkland CL, Spaggiari CV, Oorschot C, Wingate MTD, Taylor RJ (2014) Proterozoic granulite formation driven by mafic magmatism: An example from the Fraser Range Metamorphics, Western Australia. Precambrian Res 240:1-21

Clark DJ, Hensen BJ, Kinny PD (2000) Geochronological constraints for a two-stage history of the Albany-Fraser Orogen, Western Australia. Precambrian Res 102:155-183

Clarke GL, Guiraud M, Powell R, Burg JP (1987) Metamorphism in the Olary Block, South Australia: compression with cooling in a Proterozoic fold belt. J Metamorph Geol 5:291306

Clemens JD, Vielzeuf D (1987) Constraints on melting and magma production in the crust. Earth Planet Sci Lett 86:287-306 
Collins WJ, Vernon RH (1991) Orogeny associated with anticlockwise PTt paths: Evidence from low-P, high-T metamorphic terranes in the Arunta inlier, central Australia. Geology 19:835-838

Connolly JAD, Petrini K (2002) An automated strategy for calculation of phase diagram sections and retrieval of rock properties as a function of physical conditions. J Metamorph Geol 20:697-708

Copeland RA, Frey FA, Wones DR (1971) Origin of clay minerals in a Mid-Atlantic Ridge sediment. Earth Planet Sci Lett 10:186-192

Corrie SL, Kohn MJ (2008) Trace-element distributions in silicates during prograde metamorphic reactions: Implications for monazite formation. J Metamorph Geol 26:451464

Crowley JL, Brown RL, Gervais F, Gibson HD (2008) Assessing inheritance of zircon and monazite in granitic rocks from the Monashee Complex, Canadian Cordillera. J Petrol 49:1915-1929

Crowley JL, Waters DJ, Searle MP, Bowring SA (2009) Pleistocene melting and rapid exhumation of the Nanga Parbat massif, Pakistan: Age and P-T conditions of accessory mineral growth in migmatite and leucogranite. Earth Planet Sci Lett 288:408-420

Dawson GC, Krapež B, Fletcher IR, McNaughton NJ, Rasmussen B (2003) 1.2 Ga thermal metamorphism in the Albany-Fraser Orogen of Western Australia: consequence of collision or regional heating by dyke swarms? J Geol Soc London 160:29-37

de Capitani C, Brown TH (1987) The computation of chemical equilibrium in complex systems containing non-ideal solutions. Geochim Cosmochim Acta 51:2639-2652

de Capitani C, Petrakakis K (2010) The computation of equilibrium assemblage diagrams with Theriak/Domino software. Am Mineral 95:1006-1016

Degeling H, Eggins S, Ellis DJ (2001) Zr budgets for metamorphic reactions, and the formation of zircon from garnet breakdown. Mineral Mag 65:749-758

Diener JFA, Powell R (2010) Influence of ferric iron on the stability of mineral assemblages. J Metamorph Geol 28:599-613

Dragovic B, Baxter EF, Caddick MJ (2015) Pulsed dehydration and garnet growth during subduction revealed by zoned garnet geochronology and thermodynamic modeling, Sifnos, Greece. Earth Planet Sci Lett 413:111-122

Dragovic B, Samanta LM, Baxter EF, Selverstone J (2012) Using garnet to constrain the duration and rate of water-releasing metamorphic reactions during subduction: an example from Sifnos, Greece. Chem Geol 314:9-22

Dragovic B, Guevara VE, Caddick MJ, Baxter EF, Kylander-Clark ARC (2016) A pulse of cryptic granulite-facies metamorphism in the Archean Wyoming Craton revealed by Sm$\mathrm{Nd}$ garnet and U-Pb monazite geochronology. Precambrian Res 283:24-49

Duc-Tin Q, Keppler H (2015) Monazite and xenotime solubility in granitic melts and the origin of the lanthanide tetrad effect. Contr Mineral and Petrol 169:1-26

Enami M, Liou JG, Mattinson CG (2004) Epidote minerals in high P/T metamorphic terranes: Subduction zone and high-to ultrahigh-pressure metamorphism. Rev Mineral Geochem $56: 347-398$

\section{Engi (2017) Title of Chapter. Rev Mineral Geochem XX:xxx-Xxx}

England PC, Thompson AB (1984) Pressure-Temperature-Time Paths of Regional Metamorphism I. Heat Transfer during the Evolution of Regions of Thickened Continental Crust. J Petrol 25:894-928 
Evans TP (2004) A method for calculating effective bulk composition modification due to crystal fractionation in garnet-bearing schist: implications for isopleth thermobarometry. J Metamorph Geol 22:547-557

Ewing TA, Rubatto D, Hermann J (2014) Hafnium isotopes and Zr/Hf of rutile and zircon from lower crustal metapelites (Ivrea-Verbano Zone, Italy): implications for chemical differentiation of the crust. Earth Planet Sci Lett 389:106-118

Ferry JM, Watson EB (2007) New thermodynamic models and revised calibrations for the Ti-inzircon and Zr-in-rutile thermometers. Contr Mineral and Petrol 154:429-437

Finger F, Krenn E (2007) Three metamorphic monazite generations in a high-pressure rock from the Bohemian Massif and the potentially important role of apatite in stimulating polyphase monazite growth along a PT loop. Lithos 95:103-115

Finger F, Krenn E, Schulz B, Harlov D, Schiller D (2016) "Satellite monazites" in polymetamorphic basement rocks of the Alps: Their origin and petrological significance. Am Mineral 101:1094-1103

Fitzsimons IC, Kinny PD, Wetherley S, Hollingsworth DA (2005) Bulk chemical control on metamorphic monazite growth in pelitic schists and implications for $\mathrm{U}-\mathrm{Pb}$ age data. $\mathrm{J}$ Metamorph Geol 23:261-277

Florence FP, Spear FS (1993) Influences of reaction history and chemical diffusion on PT calculations for staurolite schists from the Littleton Formation, northwestern New Hampshire. Am Mineral 78:345-359

Foster G, Kinny P, Vance D, Prince C, Harris N (2000) The significance of monazite U-Th-Pb age data in metamorphic assemblages; a combined study of monazite and garnet chronometry. Earth Planet Sci Lett 181:327-340

Foster G, Gibson H, Parrish RR, Horstwood MSA, Fraser J, Tindle A (2002) Textural, chemical and isotopic insights into the nature and behaviour of metamorphic monazite. Chem Geol 191:183-207

Foster G, Parrish RR, Horstwood MS, Chenery S, Pyle J, Gibson HD (2004) The generation of prograde $\mathrm{P}-\mathrm{T}-\mathrm{t}$ points and paths; a textural, compositional, and chronological study of metamorphic monazite. Earth Planet Sci Lett 228:125-142

Franz G, Andrehs G, Rhede D (1996) Crystal chemistry of monazite and xenotime from Saxothuringian-Moldanubian metapelites, NE Bavaria, Germany. European Journal of Mineralogy:1097-1118

Franz G, Morteani G, Rhede D (2015) Xenotime-(Y) formation from zircon dissolutionprecipitation and HREE fractionation: an example from a metamorphosed phosphatic sandstone, Espinhaço fold belt (Brazil). Contr Mineral and Petrol 170:1-22

Fraser G, Ellis D, Eggins S (1997) Zirconium abundance in granulite-facies minerals, with implications for zircon geochronology in high-grade rocks. Geology 25:607-610

Frei D, Liebscher A, Franz G, Dulski P (2004) Trace element geochemistry of epidote minerals. Rev Mineral Geochem 56:553-605

Frost BR, Chamberlain KR, Schumacher JC (2001) Sphene (titanite): phase relations and role as a geochronometer. Chem Geol 172:131-148

Fyfe WS (1973) The granulite facies, partial melting and the Archaean crust. Philos Trans R Soc London, Ser A 273:457-461

Gaidies F, Abart R, De Capitani C, Schuster R, Connolly JAD, Reusser E (2006) Characterization of polymetamorphism in the Austroalpine basement east of the Tauern Window using garnet isopleth thermobarometry. J Metamorph Geol 24:451-475 
1281

1282

1283

1284

1285

1286

1287

1288

1289

1290

1291

1292

1293

1294

1295

1296

1297

1298

1299

1300

1301

1302

1303

1304

1305

1306

1307

1308

1309

1310

1311

1312

1313

1314

1315

1316

1317

1318

1319

1320

1321

1322

1323

1324

1325
Gaidies F, De Capitani C, Abart R (2008) THERIA_G: a software program to numerically model prograde garnet growth. Contr Mineral and Petrol 155:657-671

Gaidies F, Pattison DRM, De Capitani C (2011) Toward a quantitative model of metamorphic nucleation and growth. Contr Mineral and Petrol 162:975-993

Gasser D, Bruand E, Rubatto D, Stüwe K (2012) The behaviour of monazite from greenschist facies phyllites to anatectic gneisses: an example from the Chugach Metamorphic Complex, southern Alaska. Lithos 134:108-122

Gervasoni F, Klemme S, Rocha-Júnior ERV, Berndt J (2016) Zircon saturation in silicate melts: a new and improved model for aluminous and alkaline melts. Contr Mineral and Petrol 171:1-12

Ghent ED (1976) Plagioclase-garnet- $\mathrm{Al}_{2} \mathrm{SiO}_{5}$-quartz: a potential geobarometer-geothermometer. Am Mineral 6:710-714

Gibson HD, Carr SD, Brown RL, Hamilton MA (2004) Correlations between chemical and age domains in monazite, and metamorphic reactions involving major pelitic phases: an integration of ID-TIMS and SHRIMP geochronology with Y-Th-U X-ray mapping. Chem Geol 211:237-260

Grapes RH, Hoskin PWO (2004) Epidote group minerals in low-medium pressure metamorphic terranes. Rev Mineral Geochem 56:301-345

Green ECR, White RW, Diener JFA, Powell R, Palin RM (2016) Activity-composition relations for the calculation of partial melting equilibria in metabasic rocks. J Metamorph Geol, doi: $10.1111 /$ jmg. 12211

Gromet LP, Silver LT (1983) Rare earth element distributions among minerals in a granodiorite and their petrogenetic implications. Geochim Cosmochim Acta 47:925-939

Guernina S, Sawyer EW (2003) Large-scale melt-depletion in granulite terranes: An example from the Archean Ashuanipi Subprovince of Quebec. J Metamorph Geol 21:181-201

Guevara VE, Caddick MJ (2016) Shooting at a moving target: phase equilibria modelling of high-temperature metamorphism. J Metamorph Geol 34:209-235.

Hacker BR, Andersen TB, Johnston S, Kylander-Clark ARC, Peterman EM, Walsh EO, Young D (2010) High-temperature deformation during continental-margin subduction \& exhumation: The ultrahigh-pressure Western Gneiss Region of Norway. Tectonophysics 480:149-171

Hacker BR, Kylander-Clark ARC, Holder R, Andersen TB, Peterman EM, Walsh EO, Munnikhuis JK (2015) Monazite response to ultrahigh-pressure subduction from U-Pb dating by laser ablation split stream. Chem Geol 409:28-41

Harlov DE, Hetherington CJ (2010) Letter. Partial high-grade alteration of monazite using alkalibearing fluids: Experiment and nature. Am Mineral 95:1105-1108

Harlov DE, Wirth R, Förster H-J (2005) An experimental study of dissolution-reprecipitation in fluorapatite: fluid infiltration and the formation of monazite. Contr Mineral and Petrol 150:268-286

Harlov DE, Wirth R, Hetherington CJ (2011) Fluid-mediated partial alteration in monazite: the role of coupled dissolution-reprecipitation in element redistribution and mass transfer. Contr Mineral and Petrol 162:329-348

Harris NBW, Caddick M, Kosler J, Goswami S, Vance D, Tindle AG (2004) The pressuretemperature-time path of migmatites from the Sikkim Himalaya. J Metamorph Geol $22: 249-264$ 
Harrison TM, Watson EB (1983) Kinetics of zircon dissolution and zirconium diffusion in granitic melts of variable water content. Contr Mineral and Petrol 84:66-72

Harrison TM, Watson EB (1984) The behavior of apatite during crustal anatexis: equilibrium and kinetic considerations. Geochim Cosmochim Acta 48:1467-1477

Hay DC, Dempster TJ (2009) Zircon behaviour during low-temperature metamorphism. J Petrol 50: 571-589.

Hayden LA, Watson EB, Wark DA (2008) A thermobarometer for sphene (titanite). Contr Mineral and Petrol 155:529-540

Hensen BJ (1971) Theoretical phase relations involving cordierite and garnet in the system $\mathrm{MgO}-\mathrm{FeO}-\mathrm{Al}$ 2O3-SiO2. Contr Mineral and Petrol 33:191-214

Hermann J, Rubatto D (2003) Relating zircon and monazite domains to garnet growth zones: age and duration of granulite facies metamorphism in the Val Malenco lower crust. $J$ Metamorph Geol 21:833-852

Hermann J, Rubatto D, Korsakov A, Shatsky VS (2001) Multiple zircon growth during fast exhumation of diamondiferous, deeply subducted continental crust (Kokchetav Massif, Kazakhstan). Contr Mineral and Petrol 141:66-82

Hiess J, Nutman AP, Bennett VC, Holden P (2008) Ti-in-zircon thermometry applied to contrasting Archean metamorphic and igneous systems. Chem Geol 247:323-338

Hofmann AE, Baker MB, Eiler JM (2013) An experimental study of Ti and Zr partitioning among zircon, rutile, and granitic melt. Contr Mineral and Petrol 166:235-253

Holder RM, Hacker BR, Kylander-Clark ARC, Cottle JM (2015) Monazite trace-element and isotopic signatures of (ultra) high-pressure metamorphism: Examples from the Western Gneiss Region, Norway. Chem Geol 409:99-111

Holland TJB, Powell R (1998) An internally consistent thermodynamic data set for phases of petrological interest. J Metamorph Geol 16:309-343

Holland TJB, Powell R (2011) An improved and extended internally consistent thermodynamic dataset for phases of petrological interest, involving a new equation of state for solids. $\mathrm{J}$ Metamorph Geol 29:333-383

Hoskin PWO, Schaltegger U (2003) The composition of zircon and igneous and metamorphic petrogenesis. Rev Mineral Geochem 53:27-62

Huang WL, Wyllie PJ (1973) Melting relations of muscovite-granite to $35 \mathrm{kbar}$ as a model for fusion of metamorphosed subducted oceanic sediments. Contr Mineral and Petrol 42:1-14

Jamieson RA, Beaumont C, Medvedev S, Nguyen MH (2004) Crustal channel flows: 2. Numerical models with implications for metamorphism in the Himalayan-Tibetan orogen. J Geophys Res B: Solid Earth 109:2156-2202

Janots E, Engi M, Berger A, Allaz J, Schwarz JO, Spandler C (2008) Prograde metamorphic sequence of REE minerals in pelitic rocks of the Central Alps: implications for allanitemonazite-xenotime phase relations from 250 to 610 C. J Metamorph Geol 26:509-526

Janots E, Engi M, Rubatto D, Berger A, Gregory C, Rahn M (2009) Metamorphic rates in collisional orogeny from in situ allanite and monazite dating. Geology 37:11-14

Johnson TE, White RW, Powell R (2008) Partial melting of metagreywacke: a calculated mineral equilibria study. J Metamorph Geol 26:837-853

Johnson TE, Clark C, Taylor RJM, Santosh M, Collins AS (2015) Prograde and retrograde growth of monazite in migmatites: An example from the Nagercoil Block, southern India. Geosci Front 6:373-387 
Kapp P, Manning CE, Tropper P (2009) Phase-equilibrium constraints on titanite and rutile activities in mafic epidote amphibolites and geobarometry using titanite-rutile equilibria. J Metamorph Geol 27:509-521

Kawakami T, Yamaguchi I, Miyake A, Shibata T, Maki K, Yokoyama TD, Hirata T (2013) Behavior of zircon in the upper-amphibolite to granulite facies schist/migmatite transition, Ryoke metamorphic belt, SW Japan: constraints from the melt inclusions in zircon. Contr Mineral and Petrol 165:575-591

Kelsey DE, Powell R (2011) Progress in linking accessory mineral growth and breakdown to major mineral evolution in metamorphic rocks: a thermodynamic approach in the $\mathrm{Na} 2 \mathrm{O}-$ $\mathrm{CaO}-\mathrm{K} 2 \mathrm{O}-\mathrm{FeO}-\mathrm{MgO}-\mathrm{Al} 2 \mathrm{O} 3-\mathrm{SiO} 2-\mathrm{H} 2 \mathrm{O}-\mathrm{TiO} 2-\mathrm{ZrO} 2$ system. J Metamorph Geol 29:151166

Kelsey DE, Hand M (2015) On ultrahigh temperature crustal metamorphism: phase equilibria, trace element thermometry, bulk composition, heat sources, timescales and tectonic settings. Geosci Front 6:311-356

Kelsey DE, Clark C, Hand M (2008) Thermobarometric modelling of zircon and monazite growth in melt-bearing systems: examples using model metapelitic and metapsammitic granulites. J Metamorph Geol 26:199-212

Kingsbury JA, Miller CF, Wooden JL, Harrison TM (1993) Monazite paragenesis and U-Pb systematics in rocks of the eastern Mojave Desert, California, USA: implications for thermochronometry. Chem Geol 110:147-167

Kirkland CL, Spaggiari CV, Johnson TE, Smithies RH, Danišík M, Evans N, Wingate MTD, Clark C, Spencer C, Mikucki E, McDonald BJ (2016) Grain size matters: Implications for element and isotopic mobility in titanite. Precambrian Res 278:283-302

Kohn MJ (2008) PTt data from central Nepal support critical taper and repudiate large-scale channel flow of the Greater Himalayan Sequence. Geol Soc Am Bull 120:259-273

Kohn MJ, Spear F (2000) Retrograde net transfer reaction insurance for pressure-temperature estimates. Geology 28:1127-1130

Kohn MJ, Malloy MA (2004) Formation of monazite via prograde metamorphic reactions among common silicates: implications for age determinations. Geochim Cosmochim Acta 68:101-113

Kohn MJ, Corrie SL, Markley C (2015) The fall and rise of metamorphic zircon. Am Mineral 100:897-908

\section{Kohn (2017) Title of Chapter. Rev Mineral Geochem XX:xxx-xxx.}

Korhonen F,J Brown M, Clark C, Bhattacharya S (2013a) Osumilite-melt interactions in ultrahigh temperature granulites: phase equilibria modelling and implications for the $\mathrm{P}-$ T-t evolution of the Eastern Ghats Province, India. J Metamorph Geol 31:881-907

Korhonen FJ, Clark C, Brown M, Bhattacharya S, Taylor R (2013b) How long-lived is ultrahigh temperature (UHT) metamorphism? Constraints from zircon and monazite geochronology in the Eastern Ghats orogenic belt, India. Precambrian Res 234:322-350

Korhonen FJ, Clark C, Brown M, Taylor RJM (2014) Taking the temperature of Earth's hottest crust. Earth Planet Sci Lett 408:341-354

Korhonen FJ, Brown M, Grove M, Siddoway CS, Baxter EF, Inglis JD (2012) Separating metamorphic events in the Fosdick migmatite-granite complex, West Antarctica. J Metamorph Geol 30:165-192

Kylander-Clark ARC, Hacker BR, Cottle JM (2013) Laser-ablation split-stream ICP petrochronology. Chem Geol 345:99-112 
Lanari and Engi (2017) Title of Chapter. Rev Mineral Geochem XX:xxx-xxx.

Mahar EM, Baker JM, Powell R, Holland TJB, Howell N (1997) The effect of Mn on mineral stability in metapelites. J Metamorph Geol 15:223-238

Mayne MJ, Moyen JF, Stevens G, Kaisl Aniemi L (2016) Rcrust: a tool for calculating path dependent open system processes and application to melt loss. J Metamorph Geol 34: 663-682.

McClelland WC, Lapen TJ (2013) Linking time to the pressure-temperature path for ultrahighpressure rocks. Elements 9:273-279

Mezger K, Hanson GN, Bohlen SR (1989) High-precision U-Pb ages of metamorphic rutile: application to the cooling history of high-grade terranes. Earth Planet Sci Lett 96:106-118

Miyazaki K (1991) Ostwald ripening of garnet in high P/T metamorphic rocks. Contr Mineral and Petrol 108:118-128

Miyazaki K (1996) A numerical simulation of textural evolution due to Ostwald ripening in metamorphic rocks: A case for small amount of volume of dispersed crystals. Geochim Cosmochim Acta 60:277-290

Molina JF, Moreno JA, Castro A, Rodríguez C, Fershtater GB (2015) Calcic amphibole thermobarometry in metamorphic and igneous rocks: New calibrations based on plagioclase/amphibole Al-Si partitioning and amphibole/liquid Mg partitioning. Lithos 232:286-305

Montel, J-M Kornprobst, J Vielzeuf, D (2000) Preservation of old U-Th-Pb ages in shielded monazite: example from the Beni Bousera Hercynian kinzigites (Morocco). J Metamorph Geol 18:335-342

Montel J-M (1986) Experimental determination of the solubility of Ce-monazite in SiO2-A12O3K2O-Na2O melts at 800 C, 2 kbar, under H2O-saturated conditions. Geology 14:659662

Morrissey LJ, Hand M, Raimondo T, Kelsey DE (2014) Long-lived high-T, low-P granulite facies metamorphism in the Arunta Region, central Australia. J Metamorph Geol 32:2547

Moynihan DP, Pattison DRM (2013) An automated method for the calculation of P-T paths from garnet zoning, with application to metapelitic schist from the Kootenay Arc, British Columbia, Canada. J Metamorph Geol 31:525-548

Mulcahy SR, Vervoort JD, Renne PR (2014) Dating subduction-zone metamorphism with combined garnet and lawsonite Lu-Hf geochronology. J Metamorph Geol 32:515-533

Nemchin AA, Bodorkos S (2000) Zr and LREE concentrations in anatectic melt as a function of crystal size distributions of zircon and monazite in the source region. Geological Society of America, Abstracts and Programs: 52286

Nemchin AA, Giannini LM, Bodorkos S, Oliver NHS (2001) Ostwald ripening as a possible mechanism for zircon overgrowth formation during anatexis: theoretical constraints, a numerical model, and its application to pelitic migmatites of the Tickalara Metamorphics, northwestern Australia. Geochim Cosmochim Acta 65:2771-2788

O'Brien PJ, Rötzler J (2003) High-pressure granulites: formation, recovery of peak conditions and implications for tectonics. J Metamorph Geol 21:3-20

Parrish RR (1990) U-Pb dating of monazite and its application to geological problems. Can J Earth Sci 27:1431-1450 
1461

1462

1463

1464

1465

1466

1467

1468

1469

1470

1471

1472

1473

1474

1475

1476

1477

1478

1479

1480

1481

1482

1483

1484

1485

1486

1487

1488

1489

1490

1491

1492

1493

1494

1495

1496

1497

1498

1499

1500

1501

1502

1503

1504

1505

Pattison DRM, Tinkham DK (2009) Interplay between equilibrium and kinetics in prograde metamorphism of pelites: an example from the Nelson aureole, British Columbia. J Metamorph Geol 27:249-279

Pattison DRM, DeBuhr CL (2015) Petrology of metapelites in the Bugaboo aureole, British Columbia, Canada. J Metamorph Geol 33:437-462

Pattison DRM, Chacko T, Farquhar J, McFarlane CRM (2003) Temperatures of granulite-facies metamorphism: constraints from experimental phase equilibria and thermobarometry corrected for retrograde exchange. J Petrol 44:867-900

Pichavant M, Montel J-M, Richard LR (1992) Apatite solubility in peraluminous liquids: Experimental data and an extension of the Harrison-Watson model. Geochim Cosmochim Acta 56:3855-3861

Powell R (1983) Processes in granulite-facies metamorphism. In: Proceedings of the Geochemical Group of the Mineraological Society: Migmatites, melting and metamorphism. Atherton, MP, Gribble, CD (eds). Shiva, Nantwich, p 127-139

Powell R, Holland TJB (1988) An internally consistent dataset with uncertainties and correlations: 3. Applications to geobarometry, worked examples and a computer program. J Metamorph Geol 6:173-204

Powell R, Holland TJB (2008) On thermobarometry. J Metamorph Geol 26:155-179

Powell R, Holland T, Worley B (1998) Calculating phase diagrams involving solid solutions via non-linear equations, with examples using THERMOCALC. J Metamorph Geol 16:577588

Powell R, Guiraud M, White RW (2005) Truth and beauty in metamorphic phase-equilibria: conjugate variables and phase diagrams. Can Mineral 43:21-33

Pyle JM, Spear FS (1999) Yttrium zoning in garnet: coupling of major and accessory phases during metamorphic reactions. Geol Mat Res 1:1-49

Pyle JM, Spear FS (2000) An empirical garnet (YAG)-xenotime thermometer. Contr Mineral and Petrol 138:51-58

Pyle JM, Spear FS, Rudnick RL, McDonough WF (2001) Monazite-xenotime-garnet equilibrium in metapelites and a new monazite-garnet thermometer. J Petrol 42:20832107

Rapp RP, Watson EB (1986) Monazite solubility and dissolution kinetics: implications for the thorium and light rare earth chemistry of felsic magmas. Contr Mineral and Petrol 94:304-316

Rapp RP, Ryerson FJ, Miller CF (1987) Experimental evidence bearing on the stability of monazite during crustal anaatexis. Geophys Res Lett 14:307-310

Rasmussen B (2005) Radiometric dating of sedimentary rocks: the application of diagenetic xenotime geochronology. Earth Sci Rev 68:197-243

Rasmussen B, Muhling JR (2007) Monazite begets monazite: evidence for dissolution of detrital monazite and reprecipitation of syntectonic monazite during low-grade regional metamorphism. Contr Mineral and Petrol 154:675-689

Rasmussen B, Fletcher IR, Muhling JR (2011) Response of xenotime to prograde metamorphism. Contr Mineral and Petrol 162:1259-1277

Regis D, Warren CJ, Mottram CM, Roberts NMW (2016) Using monazite and zircon petrochronology to constrain the $\mathrm{P}-\mathrm{T}-\mathrm{t}$ evolution of the middle crust in the Bhutan Himalaya. J Metamorph Geol 
Reno BL, Piccoli PM, Brown M, Trouw RAJ (2012) In situ monazite (U-Th)-Pb ages from the Southern Brasília Belt, Brazil: constraints on the high-temperature retrograde evolution of HP granulites. J Metamorph Geol 30:81-112

Roberts MP, Finger F (1997) Do U-Pb zircon ages from granulites reflect peak metamorphic conditions? Geology 25:319-322

Rocha BC, Moraes R, Möller A, Cioffi CR, Jercinovic MJ (2016) Timing of anatexis and melt crystallization in the Socorro-Guaxupé Nappe, SE Brazil: Insights from trace element composition of zircon, monazite and garnet coupled to $\mathrm{U}-\mathrm{Pb}$ geochronology. Lithos

\section{Rubatto (2017) Title of Chapter. Rev Mineral Geochem XX:xxx-Xxx}

Rubatto D (2002) Zircon trace element geochemistry: partitioning with garnet and the link between U-Pb ages and metamorphism. Chem Geol 184:123-138

Rubatto D, Hermann J (2003) Zircon formation during fluid circulation in eclogites (Monviso, Western Alps): implications for $\mathrm{Zr}$ and Hf budget in subduction zones. Geochim Cosmochim Acta 67:2173-2187

Rubatto D, Hermann J (2007) Experimental zircon/melt and zircon/garnet trace element partitioning and implications for the geochronology of crustal rocks. Chem Geol 241:3861

Rubatto D, Williams IS, Buick IS (2001) Zircon and monazite response to prograde metamorphism in the Reynolds Range, central Australia. Contr Mineral and Petrol 140:458-468

Rubatto D, Chakraborty S, Dasgupta S (2013) Timescales of crustal melting in the Higher Himalayan Crystallines (Sikkim, Eastern Himalaya) inferred from trace elementconstrained monazite and zircon chronology. Contr Mineral and Petrol 165:349-372

Schaltegger U (2007) Hydrothermal zircon. Elements 3:51-79

Schaltegger U, Fanning CM, Günther D, Maurin JC, Schulmann K, Gebauer D (1999) Growth, annealing and recrystallization of zircon and preservation of monazite in high-grade metamorphism: conventional and in-situ U-Pb isotope, cathodoluminescence and microchemical evidence. Contr Mineral and Petrol 134:186-201

Sheppard S, Rasmussen B, Muhling JR, Farrell TR, Fletcher IR (2007) Grenvillian-aged orogenesis in the Palaeoproterozoic Gascoyne Complex, Western Australia: 1030-950 Ma reworking of the Proterozoic Capricorn Orogen. J Metamorph Geol 25:477-494

Shaw DM (1956) Geochemistry of pelitic rocks. Part III: Major elements and general geochemistry. Geol Soc Am Bull 67:919-934

Shazia JR, Harlov DE, Suzuki K, Kim SW, Girish-Kumar M, Hayasaka Y, Ishwar-Kumar C, Windley BF, Sajeev K (2015) Linking monazite geochronology with fluid infiltration and metamorphic histories: Nature and experiment. Lithos 236:1-15

Skora S, Blundy J (2012) Monazite solubility in hydrous silicic melts at high pressure conditions relevant to subduction zone metamorphism. Earth Planet Sci Lett 321:104-114

Sláma J, Košler J, Pedersen RB (2007) Behaviour of zircon in high-grade metamorphic rocks: evidence from Hf isotopes, trace elements and textural studies. Contr Mineral and Petrol 154:335-356

Smith HA, Barreiro B (1990) Monazite U-Pb dating of staurolite grade metamorphism in pelitic schists. Contr Mineral and Petrol 105:602-615

Smye AJ, Stockli DF (2014) Rutile U-Pb age depth profiling: A continuous record of lithospheric thermal evolution. Earth Planet Sci Lett 408:171-182 
Spear FS (1995) Metamorphic phase equilibria and pressure-temperature-time paths. Mineralogical Society of America Washington

Spear FS (2010) Monazite-allanite phase relations in metapelites. Chem Geol 279:55-62 Spear FS, Florence FP (1992) Thermobarometry in granulites: pitfalls and new approaches. Precambrian Res 55:209-241

Spear FS, Pyle JM (2002) Apatite, monazite, and xenotime in metamorphic rocks. Rev Mineral Geochem 48:293-335

Spear FS, Pyle JM (2010) Theoretical modeling of monazite growth in a low-Ca metapelite. Chem Geol 273:111-119

Spear FS, Pattison DRM, Cheney JT (2016) The metamorphosis of metamorphic petrology. Geol Soc Am Sp Pap 523:SPE523-502

Spencer KJ, Hacker BR, Kylander-Clark ARC, Andersen TB, Cottle JM, Stearns MA, Poletti JE, Seward GGE (2013) Campaign-style titanite U-Pb dating by laser-ablation ICP: implications for crustal flow, phase transformations and titanite closure. Chem Geol 341:84-101

Stearns MA, Hacker BR, Ratschbacher L, Rutte D, Kylander-Clark ARC (2015) Titanite petrochronology of the Pamir gneiss domes: Implications for middle to deep crust exhumation and titanite closure to $\mathrm{Pb}$ and $\mathrm{Zr}$ diffusion. Tectonics 34:784-802

Stepanov AS, Hermann J, Rubatto D, Rapp RP (2012) Experimental study of monazite/melt partitioning with implications for the REE, Th and U geochemistry of crustal rocks. Chem Geol 300:200-220

Štípská P, Hacker BR, Racek M, Holder R, Kylander-Clark ARC, Schulmann K, Hasalová P (2015) Monazite Dating of Prograde and Retrograde P-T-d paths in the Barrovian terrane of the Thaya window, Bohemian Massif. J Petrol 56:1007-1035

Stüwe K (1997) Effective bulk composition changes due to cooling: a model predicting complexities in retrograde reaction textures. Contr Mineral and Petrol 129:43-52

Stüwe K, Powell R (1995) PT paths from modal proportions: application to the Koralm Complex, Eastern Alps. Contr Mineral and Petrol 119:83-93

Sun S-S, McDonough W (1989) Chemical and isotopic systematics of oceanic basalts: implications for mantle composition and processes. Geol Soc London, Sp Pub 42:313345

Suzuki K, Adachi M (1994) Middle Precambrian detrital monazite and zircon from the Hida gneiss on Oki-Dogo Island, Japan: their origin and implications for the correlation of basement gneiss of Southwest Japan and Korea. Tectonophysics 235:277-292

Symmes GH, Ferry JM (1992) The effect of whole-rock MnO content on the stability of garnet in pelitic schists during metamorphism. J Metamorph Geol 10:221-237

Taylor RJM, Clark C, Fitzsimons ICW, Santosh M, Hand M, Evans N, McDonald B (2014) Post-peak, fluid-mediated modification of granulite facies zircon and monazite in the Trivandrum Block, southern India. Contr Mineral and Petrol 168:1-17

Taylor RJM, Harley SL, Hinton RW, Elphick S, Clark C, Kelly NM (2015) Experimental determination of REE partition coefficients between zircon, garnet and melt: a key to understanding high-T crustal processes. J Metamorph Geol 33:231-248

Taylor-Jones K, Powell R (2015) Interpreting zirconium-in-rutile thermometric results. J Metamorph Geol 33:115-122

Thompson AB (1982) Dehydration melting of pelitic rocks and the generation of $\mathrm{H}_{2} \mathrm{O}$ undersaturated granitic liquids. Am J Sci 282:1567-1595 
Thompson AB (1996) Fertility of crustal rocks during anatexis. Geol Soc Am Sp Pap 315:1-10 Thompson AB, England PC (1984) Pressure-temperature - time paths of regional metamorphism II. Their inference and interpretation using mineral assemblages in metamorphic rocks. J Petrol 25:929-955

Tikare V, Cawley JD (1998) Application of the Potts model to simulation of Ostwald ripening. J Am Ceram Soc 81:485-491

Tomaschek F, Kennedy AK, Villa IM, Lagos M, Ballhaus C (2003) Zircons from Syros, Cyclades, Greece - recrystallization and mobilization of zircon during high-pressure metamorphism. J Petrol 44:1977-2002

Tomkins HS, Powell R, Ellis DJ (2007) The pressure dependence of the zirconium-in-rutile thermometer. J Metamorph Geol 25:703-713

Vance D, O'Nions RK (1990) Isotopic chronometry of zoned garnets: growth kinetics and metamorphic histories. Earth Planet Sci Lett 97:227-240

Vance D, Mahar E (1998) Pressure-temperature paths from PT pseudosections and zoned garnets: potential, limitations and examples from the Zanskar Himalaya, NW India. Contr Mineral and Petrol 132:225-245

Vavra G, Schmid R, Gebauer D (1999) Internal morphology, habit and U-Th-Pb microanalysis of amphibolite-to-granulite facies zircons: geochronology of the Ivrea Zone (Southern Alps). Contr Mineral and Petrol 134:380-404

Vernon RH (1996) Problems with inferring P-T-t paths in low-P granulite facies rocks. J Metamorph Geol 14:143-153

Vielzeuf D, Schmidt MW (2001) Melting relations in hydrous systems revisited: application to metapelites, metagreywackes and metabasalts. Contr Mineral and Petrol 141:251-267

Walsh AK, Kelsey DE, Kirkland CL, Hand M, Smithies RH, Clark C, Howard HM (2015) P-T-t evolution of a large, long-lived, ultrahigh-temperature Grenvillian belt in central Australia. Gondwana Res 28:531-564

Wark DA, Watson EB (2006) TitaniQ: a titanium-in-quartz geothermometer. Contr Mineral and Petrol 152:743-754

Warren CJ, Grujic D, Cottle JM, Rogers NW (2012) Constraining cooling histories: rutile and titanite chronology and diffusion modelling in NW Bhutan. J Metamorph Geol 30:113130

Watson EB (1996) Dissolution, growth and survival of zircons during crustal fusion: kinetic principles, geological models and implications for isotopic inheritance. Geol Soc Am Sp Pap 315:43-56

Watson EB, Harrison TM (1983) Zircon saturation revisited: temperature and composition effects in a variety of crustal magma types. Earth Planet Sci Lett 64:295-304

Watson EB, Vicenzi EP, Rapp RP (1989) Inclusion/host relations involving accessory minerals in high-grade metamorphic and anatectic rocks. Contr Mineral and Petrol 101:220-231

Watson EB, Wark DA, Thomas JB (2006) Crystallization thermometers for zircon and rutile. Contr Mineral and Petrol 151:413-433

Watt GR, Harley SL (1993) Accessory phase controls on the geochemistry of crustal melts and restites produced during water-undersaturated partial melting. Contr Mineral and Petrol 114:550-566

White RW, Powell R (2002) Melt loss and the preservation of granulite facies mineral assemblages. J Metamorph Geol 20:621-632 
1642

1643

1644

1645

1646

1647

1648

1649

1650

1651

1652

1653

1654

1655

1656

1657

1658

1659

1660

1661

1662

1663

1664

1665

1666

1667

1668

1669

1670

1671

1672

1673

1674

1675

1676

1677

1678

1679

1680

1681

1682

1683

1684

1685

1686

White RW, Powell R, Halpin JA (2004) Spatially-focussed melt formation in aluminous metapelites from Broken Hill, Australia. J Metamorph Geol 22:825-845

White RW, Pomroy NE, Powell R (2005) An in situ metatexite-diatexite transition in upper amphibolite facies rocks from Broken Hill, Australia. J Metamorph Geol 23:579-602

White RW, Powell R, Johnson TE (2014a) The effect of Mn on mineral stability in metapelites revisited: New a-x relations for manganese-bearing minerals. J Metamorph Geol 32:809828

White RW, Powell R, Baldwin JA (2008) Calculated phase equilibria involving chemical potentials to investigate the textural evolution of metamorphic rocks. J Metamorph Geol 26:181-198

White RW, Stevens G, Johnson TE (2011) Is the crucible reproducible? Reconciling melting experiments with thermodynamic calculations. Elements 7:241-246

White RW, Powell R, Holland TJB, Johnson TE, Green ECR (2014b) New mineral activitycomposition relations for thermodynamic calculations in metapelitic systems. J Metamorph Geol 32:261-286

White WM, Klein EM (2014) 4.13 - Composition of the Oceanic Crust. In: Treatise on Geochemsitry (Second Edition). Holland, HD, Turekian, K (ed). Elsevier, Oxford, p $457-$ 496

Williams ML, Jercinovic MJ, Harlov DE, Budzyń B, Hetherington CJ (2011) Resetting monazite ages during fluid-related alteration. Chem Geol 283:218-225

Wing BA, Ferry JM, Harrison TM (2003) Prograde destruction and formation of monazite and allanite during contact and regional metamorphism of pelites: petrology and geochronology. Contr Mineral and Petrol 145:228-250

Wolf MB, London D (1994) Apatite dissolution into peraluminous haplogranitic melts: an experimental study of solubilities and mechanisms. Geochim Cosmochim Acta 58:41274145

Wolf MB, London D (1995) Incongruent dissolution of REE-and Sr-rich apatite in peraluminous granitic liquids: Differential apatite, monazite, and xenotime solubilities during anatexis. Am Mineral 80:765-775

Worley B, Powell R (1998) Making movies: phase diagrams changing in pressure, temperature, composition and time. Geol Soc London, Sp Pub 138:269-280

Wu CM (2015) Revised empirical garnet-biotite-muscovite-plagioclase geobarometer in metapelites. J Metamorph Geol 33:167-176

Xu H, Ye K, Song Y, Chen Y, Zhang J, Liu Q, Guo S (2013) Prograde metamorphism, decompressional partial melting and subsequent melt fractional crystallization in the Weihai migmatitic gneisses, Sulu UHP terrane, eastern China. Chem Geol 341:16-37

Yakymchuk C, Brown M (2014a) Consequences of open-system melting in tectonics. J Geol Soc London 171:21-40

Yakymchuk C, Brown M (2014b) Behaviour of zircon and monazite during crustal melting. J Geol Soc London 171:465-479

Yakymchuk C, Brown M, Clark C, Korhonen FJ, Piccoli PM, Siddoway CS, Taylor RJM, Vervoort JD (2015) Decoding polyphase migmatites using geochronology and phase equilibria modelling. J Metamorph Geol 33:203-230

Yardley BWD, Valley JW (1997) The petrologic case for a dry lower crust. J Geophys Res B: Solid Earth 102:12173-12185 
1687 Zack T, Moraes R, Kronz A (2004) Temperature dependence of Zr in rutile: empirical calibration 1688 of a rutile thermometer. Contr Mineral and Petrol 148:471-488

1689 Zack T, Stockli DF, Luvizotto GL, Barth MG, Belousova E, Wolfe MR, Hinton RW (2011) In

1690 situ U-Pb rutile dating by LA-ICP-MS: 208Pb correction and prospects for geological

1691

1692

1693

1694

1695

1696

1697 applications. Contr Mineral and Petrol 162:515-530

Zack (2017). Title of Chapter. Rev Mineral Geochem XX:xxx-xxx.

Zuluaga CA, Stowell HH, Tinkham DK (2005) The effect of zoned garnet on metapelite pseudosection topology and calculated metamorphic PT paths. Am Mineral 90:16191628

1698 Figure 1. Underestimation of metamorphic temperature when the bulk rock value of $a_{\mathrm{TiO} 2}$ is less

1699 than 1.0 (the true value is shown by the contours), but a value of 1.0 is assumed in: (a) the Ti-in-

1700 quartz thermometer of Wark and Watson (2006), and (b) the Ti-in-zircon thermometer of Ferry

1701 and Watson (2007).

1702

1703 Figure 2. Compilation of the range of allanite to monazite reaction temperatures for variable

1704 bulk rock pelite compositions. Curves are from Spear (2010).

1705

1706 Figure 3. $P-T$ pseudosection for the subsolidus metapelite. The solidus is shown by the heavy

1707 dashed line.

1708

1709 Figure 4. (a) Mode-box diagram and $a_{\mathrm{TiO} 2}$ for the subsolidus clockwise $P-T$ path for the

1710 metapelite. (b) Mode-box diagram and $a_{\mathrm{TiO} 2}$ for the subsolidus hairpin $P-T$ path.

1711

1712 Figure 5. $P-T$ pseudosection for the subsolidus greywacke. The solidus is shown by the heavy

1713 dashed line.

1714 
1715 Figure 6. (a) Mode-box diagram and $a_{\mathrm{TiO} 2}$ for the subsolidus clockwise $P-T$ path for the 1716 greywacke composition. (b) Mode-box diagram and $a_{\mathrm{TiO2}}$ for the subsolidus hairpin $P-T$ path.

1718 Figure 7. $P-T$ pseudosection for suprasolidus metapelite. The solidus is shown by the heavy 1719 dashed line.

1720

1721 Figure 8. (a) Mode-box diagram and $a_{\mathrm{TiO} 2}$ for the suprasolidus clockwise $P-T$ path for the

1722 metapelite. (b) Amount of zircon and monazite remaining relative to the amount at the solidus

1723 and the ASI value of melt. (c) Mode-box diagram and $a_{\mathrm{TiO} 2}$ for the counterclockwise $P-T$ path

1724 for the metapelite. (d) Amount of zircon and monazite remaining relative to the amount at the 1725 solidus for the counterclockwise $P-T$ path.

1727 Figure 9. $P-T$ pseudosection for the suprasolidus greywacke. The solidus is shown by the heavy 1728 dashed line.

1730 Figure 10. (a) Mode-box diagram and $a_{\mathrm{TiO} 2}$ for the suprasolidus clockwise $P-T$ path for the 1731 greywacke. (b) Amount of zircon and monazite remaining relative to the amount at the solidus 1732 and the ASI value of melt. (c) Mode-box diagram and $a_{\mathrm{TiO} 2}$ for the counterclockwise $P-T$ path 1733 for the greywacke. (d) Amount of zircon and monazite remaining relative to the amount at the 1734 solidus for the counterclockwise $P-T$ path.

1736 Figure 11. $P-T$ pseudosection for the suprasolidus MORB. The solidus is shown by the heavy 1737 dashed line. 
1739 Figure 12. (a) Mode-box diagram and $a_{\mathrm{TiO} 2}$ for the suprasolidus clockwise $P-T$ path for the

1740 MORB. (b) Amount of zircon remaining relative to the amount at the solidus and the ASI value

1741 of melt.

1743 Figure 13. (a) $T-X$ pseudosection calculated at 7 kbar showing the change in mineral

1744 assemblages for compositions ranging from the metapelite (left side) to the greywacke (right

1745 side). (b) $T-X$ diagram with melt isopleths (mol\%). (c) $T-X$ diagram with the calculated amount

1746 of zircon dissolution assuming a bulk $\mathrm{Zr}$ concentration of $150 \mathrm{ppm}$. (d) Calculated amount of

1747 monazite dissolution assuming a bulk LREE concentration of $150 \mathrm{ppm}$. (e) $T-X$ diagram with

1748 contours for the complete dissolution of zircon for a range of bulk rock Zr concentrations. (f) $T-$

$1749 X$ diagram with contours for the complete dissolution of monazite for a range of bulk rock LREE

1750 concentrations.

1751

1752

Table 1. Bulk compositions used for phase equilibria modelling (mol\%)

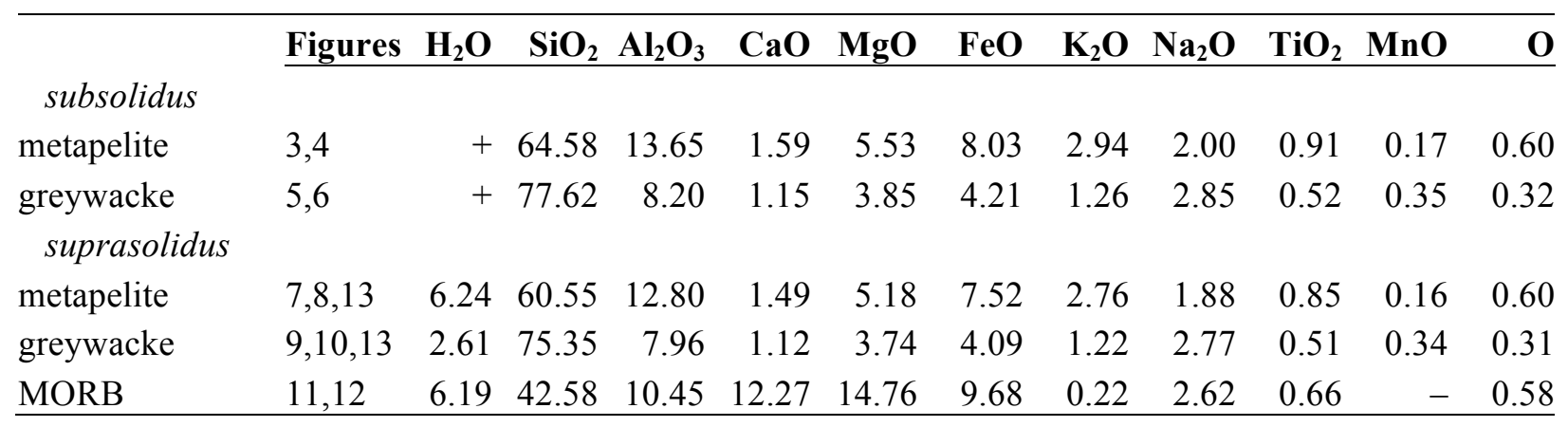


(a) Ti-in-quartz thermometer

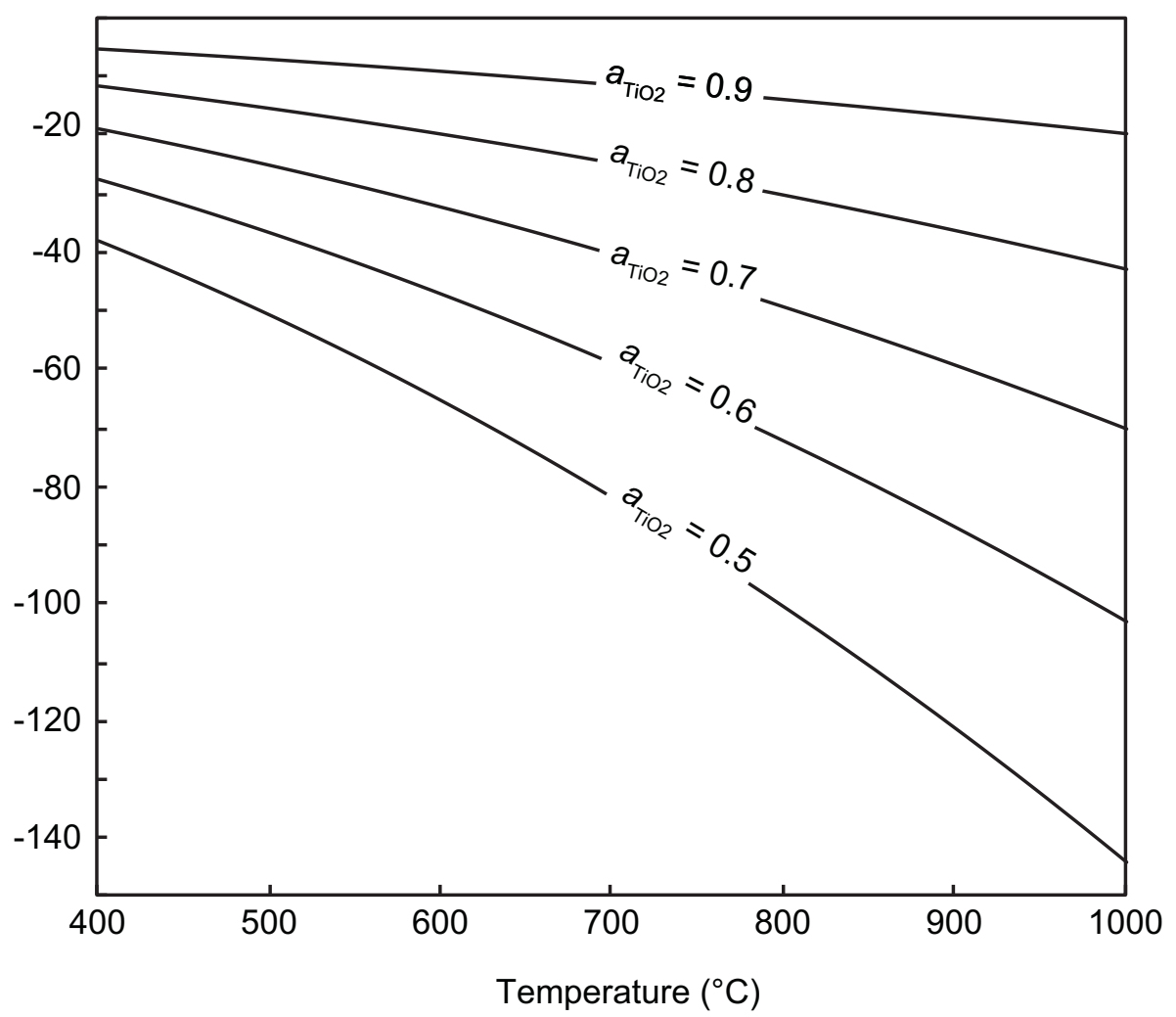

(b) Ti-in-zircon thermometer

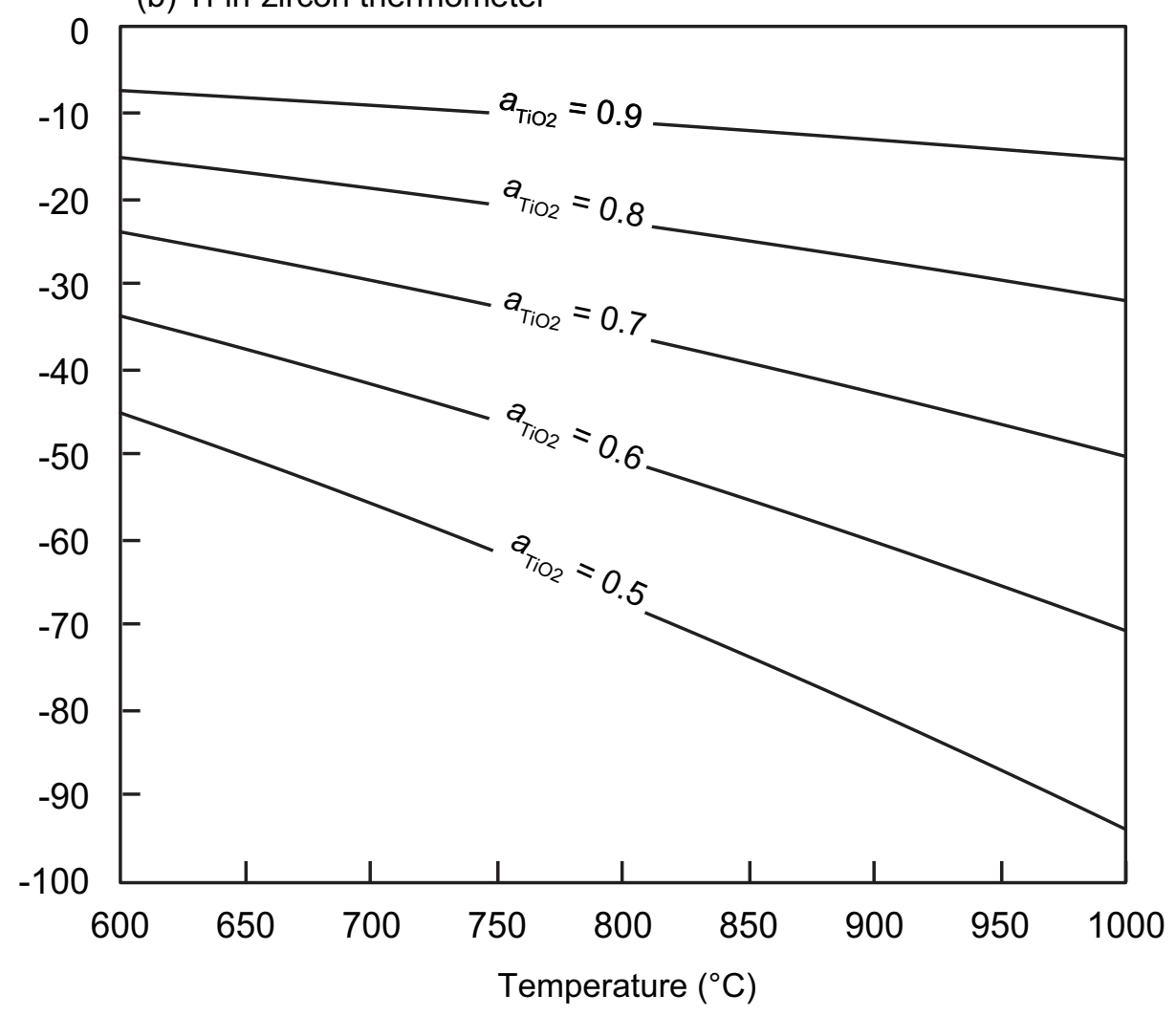

Figure 1 


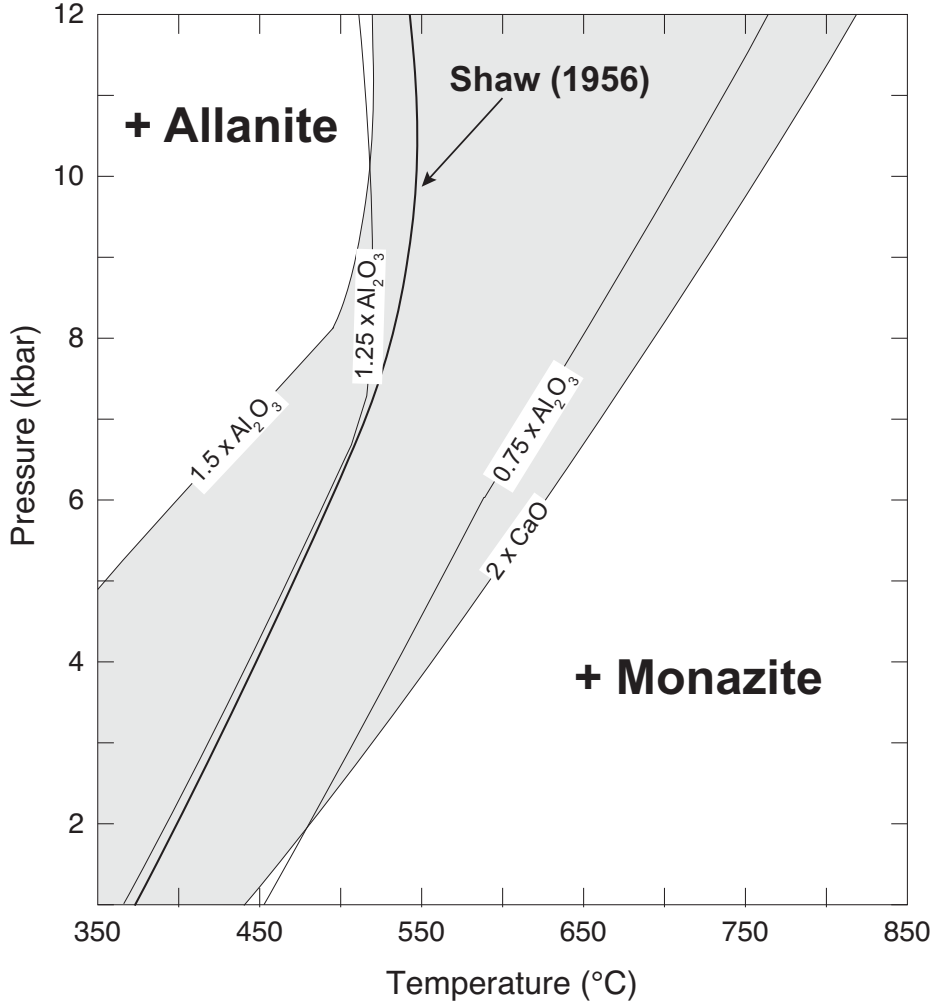

Figure 2 
Average Pelite

$+\mathrm{H}_{2} \mathrm{O}+\mathrm{q}$

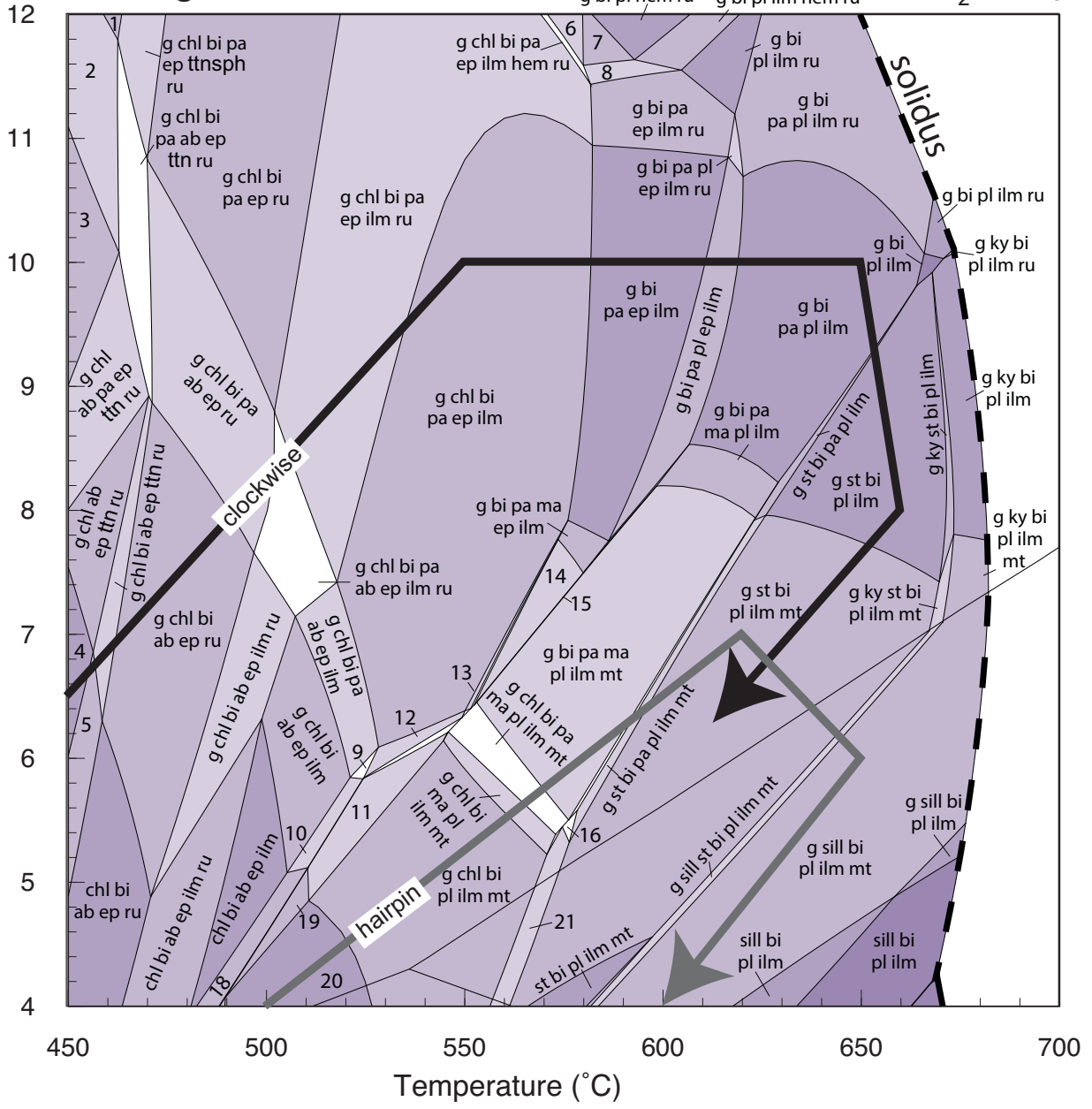

1) $g$ chl bi pa ep ttn

2) g chl bi pa ab ep ttn

3) g chl pa ab ep ttn

4) chl ab ep ttn ru

5) chl bi ab ep ttn ru
6) $\mathrm{g}$ chl bi pa ep hem ru

7) $\mathrm{g}$ bi pa ep hem ru

8) $\mathrm{g}$ bi pa ep ilm hem ru

9) $g$ chl bi pa pl ab ep ilm

10) $\mathrm{g}$ chl bi pl ab ep ilm
11) $g$ chl bi pl ep ilm mt

12) $\mathrm{g}$ chl bi pa pl ep ilm

13) $\mathrm{g}$ chl bi pa ma ep ilm

14) $\mathrm{g}$ bi pa ma ep ilm mt

15) $\mathrm{g}$ bi pa ma pl ep ilm $\mathrm{mt}$
16) g st chl bi pa pl ilm mt

17) chl bi pl ab ep ilm ru

18) chl bi pl ab ep ilm

19) chl bi pl ep ilm mt

20) chl bi pl ilm mt

21) g st chl bi pl ilm mt 


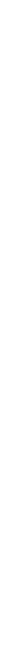

(b) Metapelite: hairpin P-T

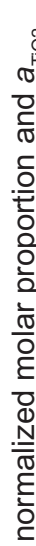

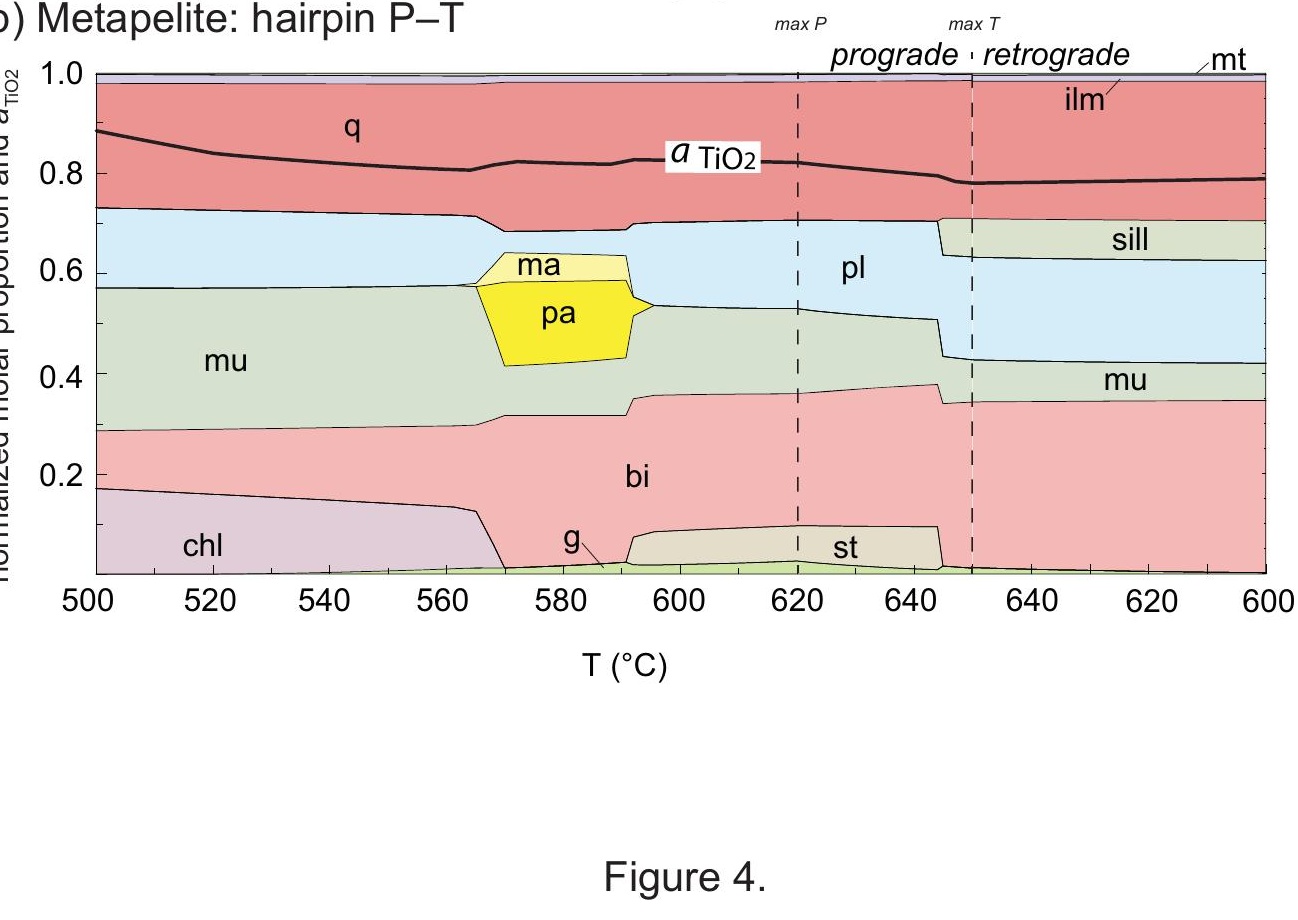

(a) Metapelite: clockwise P-T

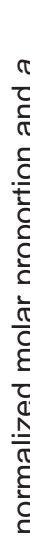

$T(C)$

XP $\quad \max T$

prograde ' retrograde

1.0 tth $\quad \mathrm{ru} \quad$ max $\mathrm{ilm} \quad$ prograde retrograde $\mathrm{mt}$

\section{Figure 4.
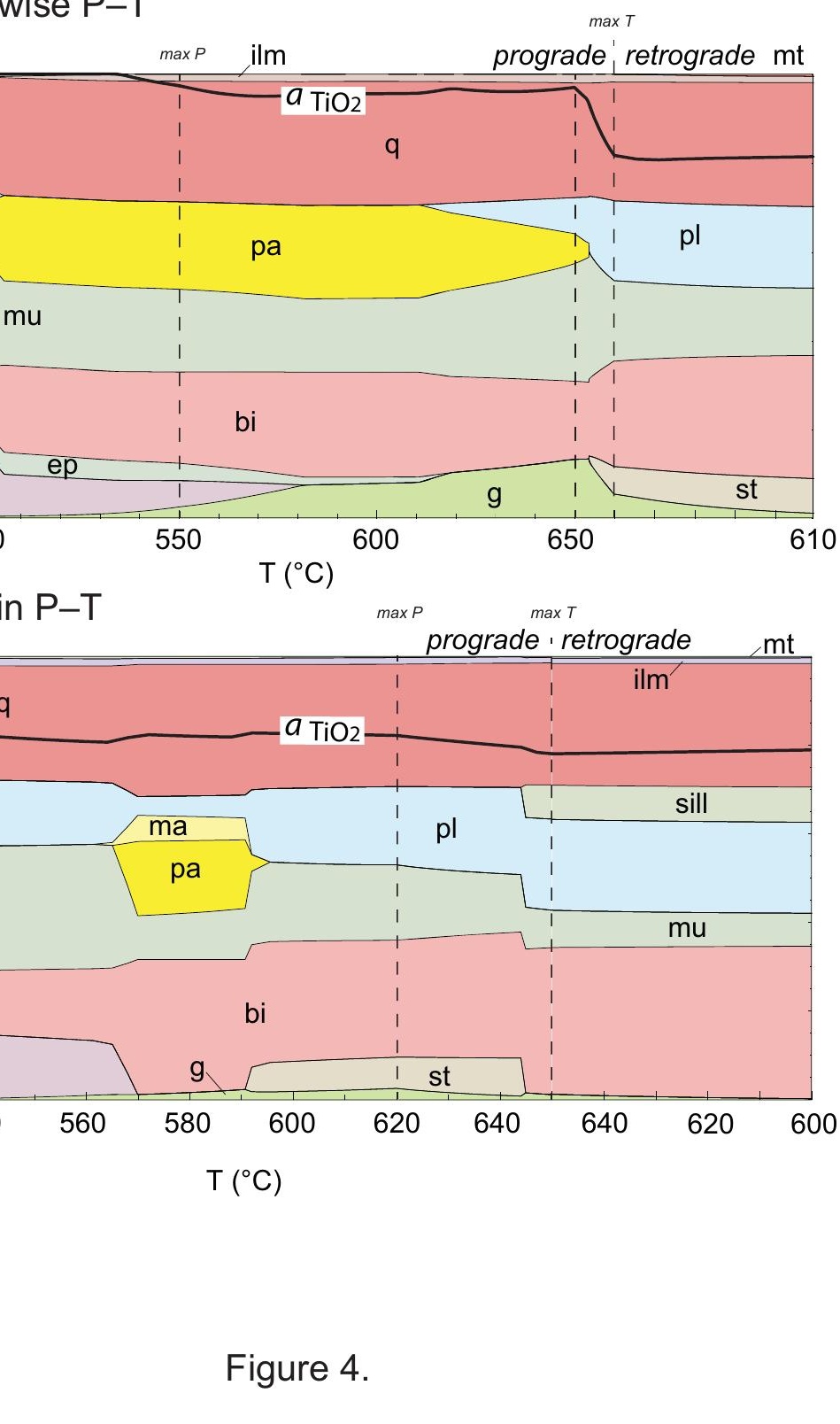


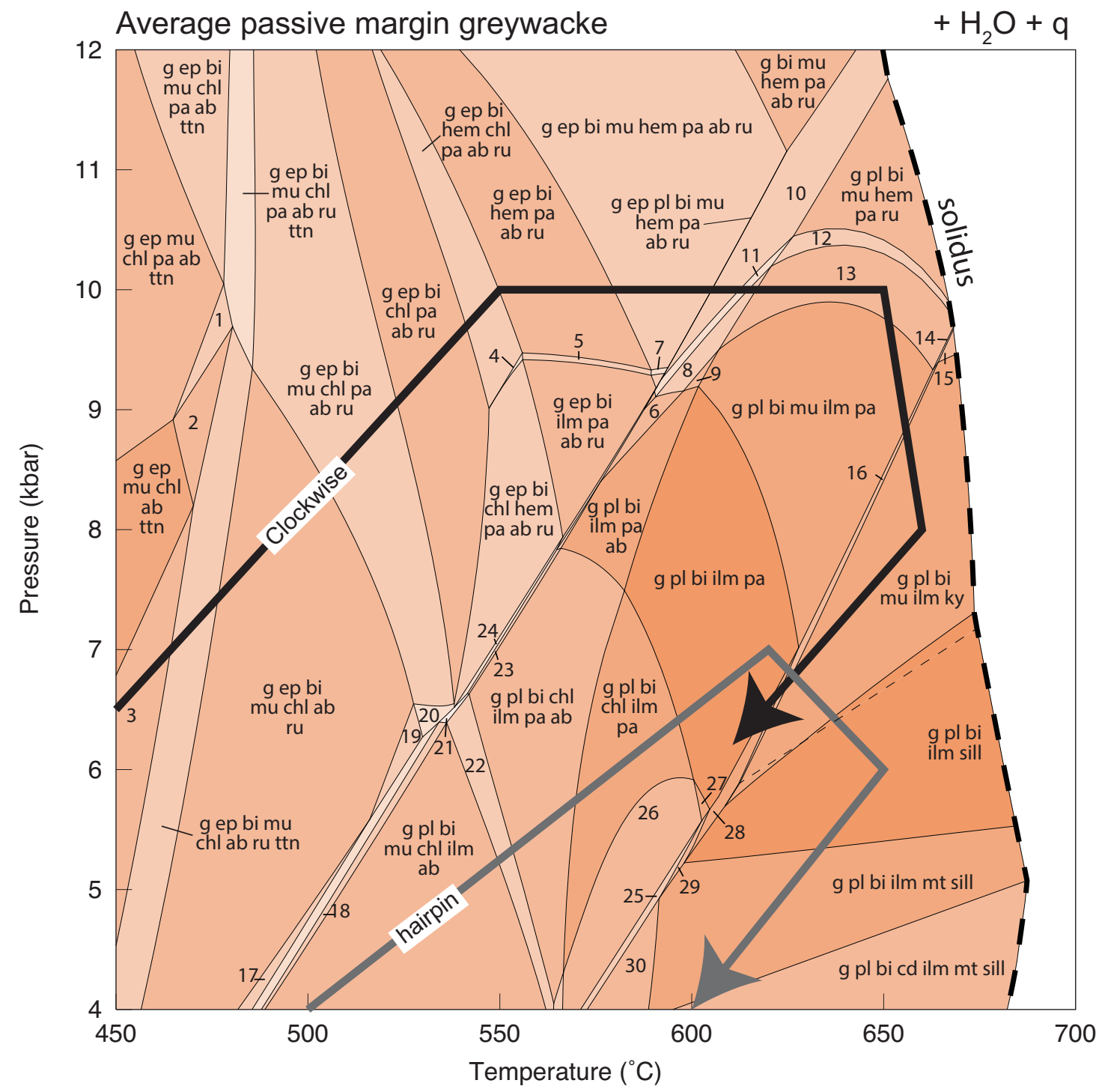

1. g ep mu chl pa ab ru ttn

2. g ep mu chl ab ru ttn

3. g ep bi mu chl ab ttn

4. g ep bi chl ilm hem pa ab ru

5. g ep bi ilm hem pa ab ru

6. g pl bi ilm pa ab ru

7. g ep pl bi mu ilm hem pa ab ru

8. g pl bi mu ilm pa ab ru

9. g pl bi mu ilm pa ab

10. g pl bi mu hem pa ab ru
11. $\mathrm{g}$ pl bi mu ilm hem pa ab ru

12. $\mathrm{g}$ pl bi mu ilm hem pa ru

13. $\mathrm{g}$ pl bi mu ilm pa ru

14. $\mathrm{g}$ pl bi mu ilm pa ru ky

15. $\mathrm{g} \mathrm{pl} \mathrm{bi} \mathrm{mu} \mathrm{ilm} \mathrm{ru} \mathrm{ky}$

16. $\mathrm{g}$ pl bi mu ilm pa ky

17. $\mathrm{g}$ pl ep bi mu chl ab ru

18. $\mathrm{g} \mathrm{pl} \mathrm{ep} \mathrm{bi} \mathrm{mu} \mathrm{chl} \mathrm{ilm} \mathrm{ab}$

19. g ep bi mu chl ilm ab ru

20. g ep bi mu chl ilm pa ab ru
21. g pl ep bi mu chl ilm pa ab ru

22. $\mathrm{g}$ pl bi mu chl ilm pa ab

23. $\mathrm{g}$ pl ep bi chl ilm pa ab

24. $\mathrm{g}$ pl ep bi chl ilm pa ab ru

25. $\mathrm{g}$ pl bi chl ilm pa $\mathrm{mt}$ sill

26. $\mathrm{g} \mathrm{pl} \mathrm{bi} \mathrm{chl} \mathrm{ilm} \mathrm{pa} \mathrm{mt}$

27. $\mathrm{g} \mathrm{pl} \mathrm{bi} \mathrm{ilm} \mathrm{pa} \mathrm{mt}$

28. $\mathrm{g} \mathrm{pl} \mathrm{bi} \mathrm{ilm} \mathrm{pa} \mathrm{sill}$

29. $\mathrm{g} \mathrm{pl} \mathrm{bi} \mathrm{ilm} \mathrm{pa} \mathrm{mt} \mathrm{sill}$

30. $\mathrm{g} \mathrm{pl} \mathrm{bi} \mathrm{chl} \mathrm{ilm} \mathrm{mt} \mathrm{sill}$ 
(a) Greywacke: clockwise P-T

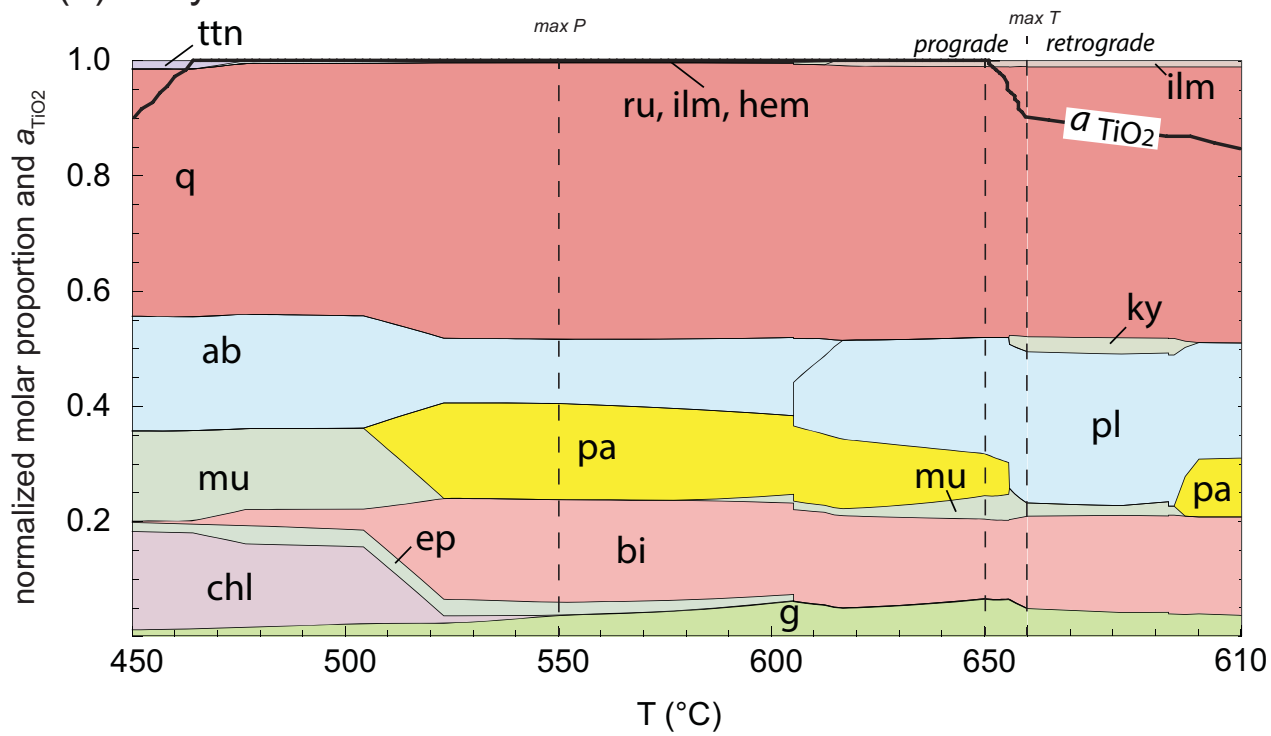

(b) Greywacke: hairpin P-T

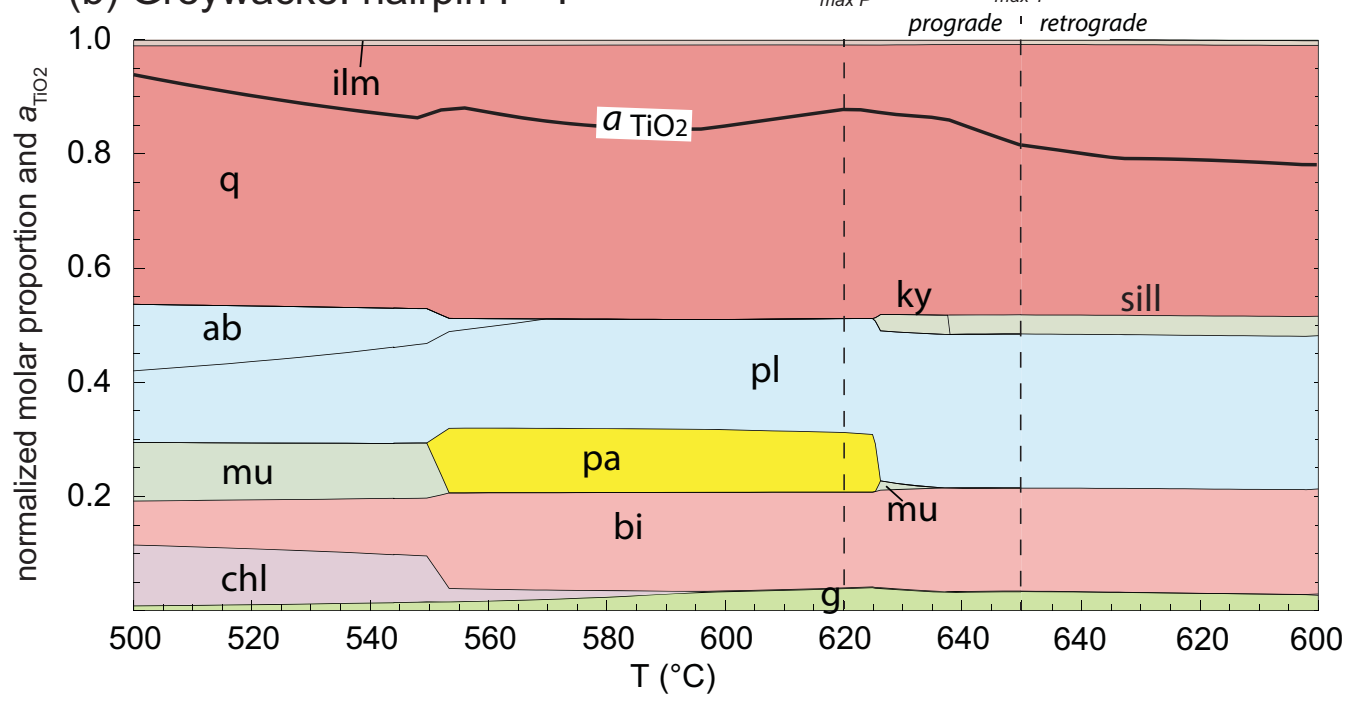

Figure 6 


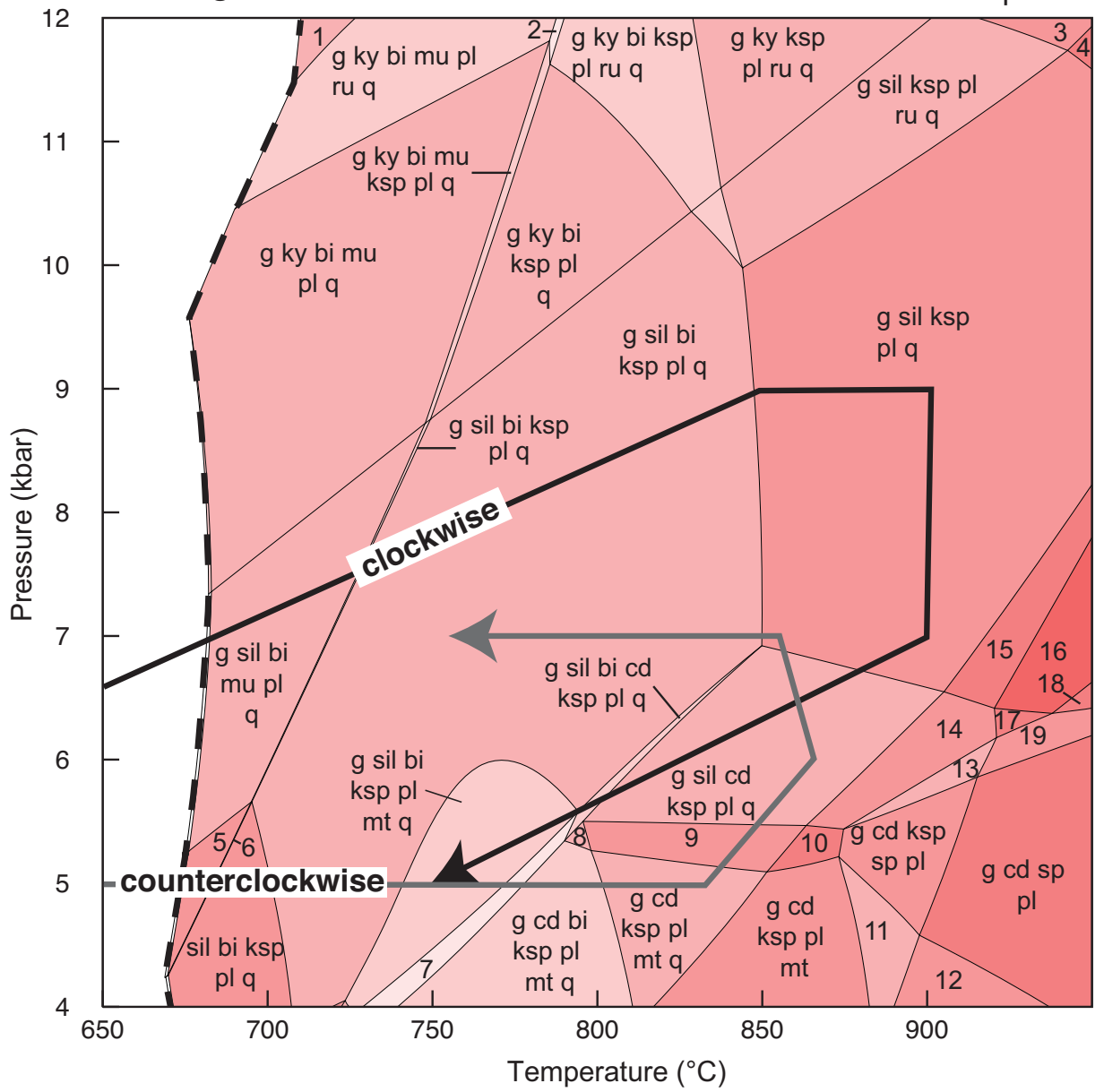

1: $g$ bi bi mu pl ru $\mathrm{q}$

2: $g$ ky bi mu ksp pl ru q

3: g sil ksp ru q

4: g sil ksp q

5: sil bi mu pl q

6: sil ksp bi mu pl q

7: g sil cd bi ksp pl mt q
8: g cd bi ksp pl q 9: g cd ksp pl ru q 10: g cd ksp pl ru 11: g cd ksp sp pl mt 12: g cd sp pl mt 13: g sil cd ksp sp pl 14: g sil cd ksp pl
15: g sil ksp pl

16: $\mathrm{g}$ sil pl

17: g sil cd pl

18: $\mathrm{g}$ sil $\mathrm{sp} \mathrm{pl}$

19: $\mathrm{g}$ sil cd $\mathrm{sp} \mathrm{pl}$

Figure 7 
Metapelite: clockwise P-T

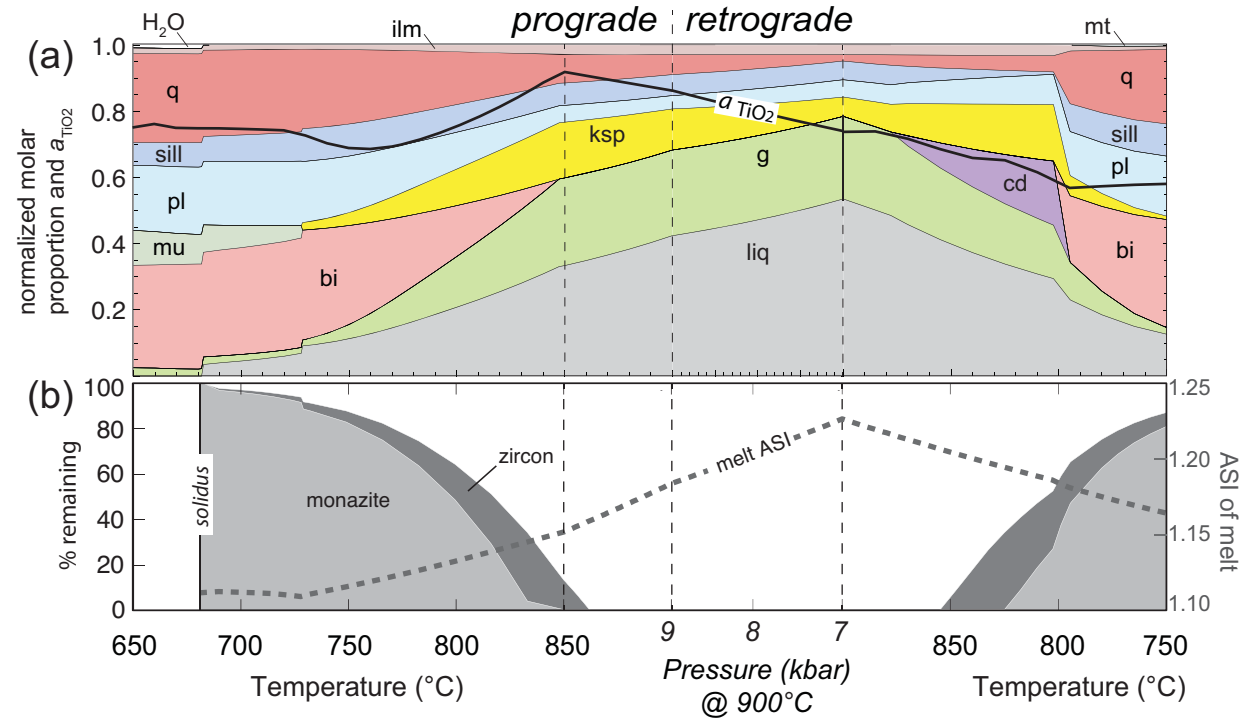

\section{Metapelite: counterclockwise $\mathrm{P}-\mathrm{T}$}

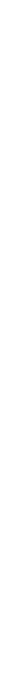

Figure 8 
Average Passive Margin Greywacke

$+q+i l m+l i q$

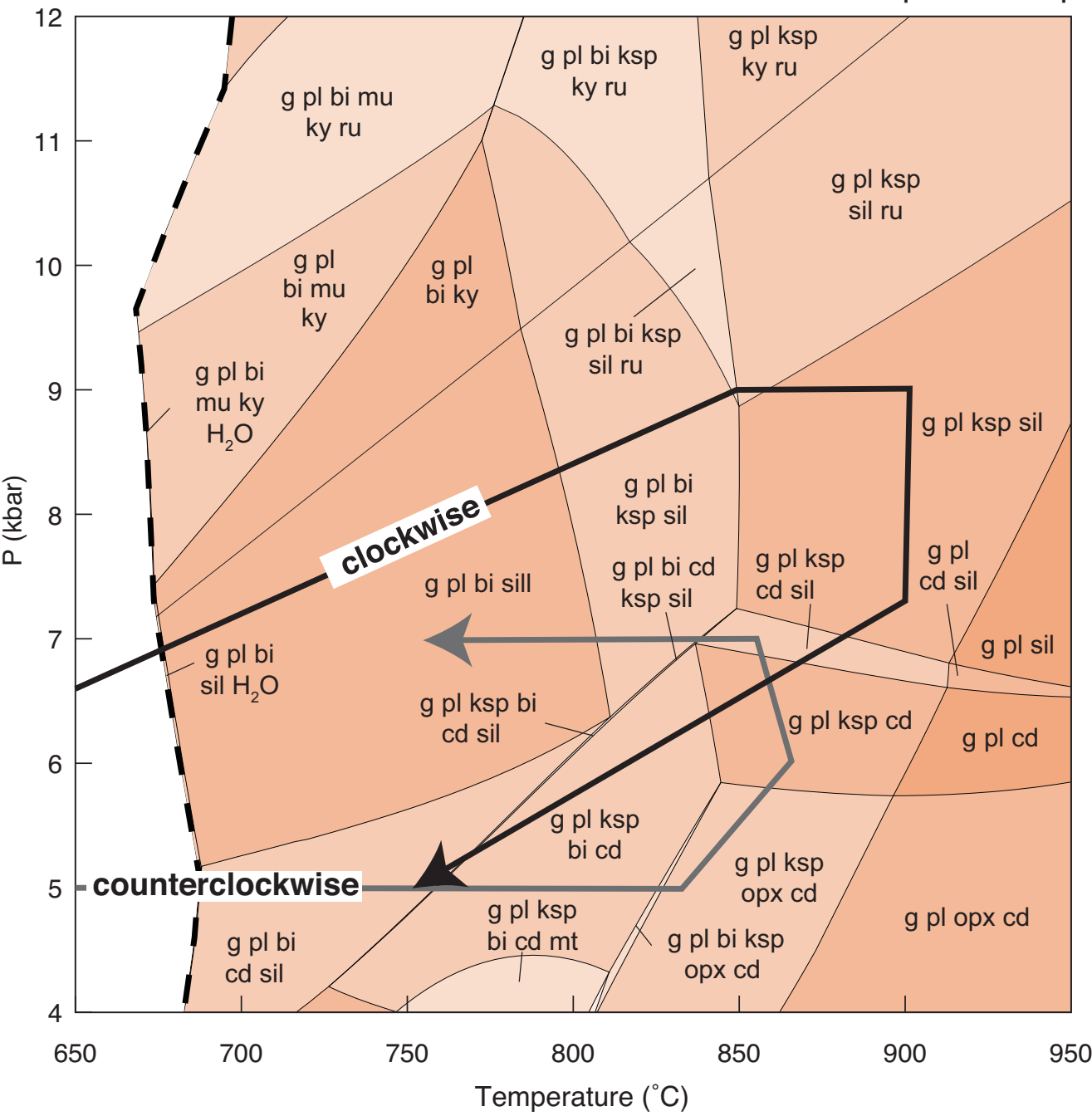

Figure 9 


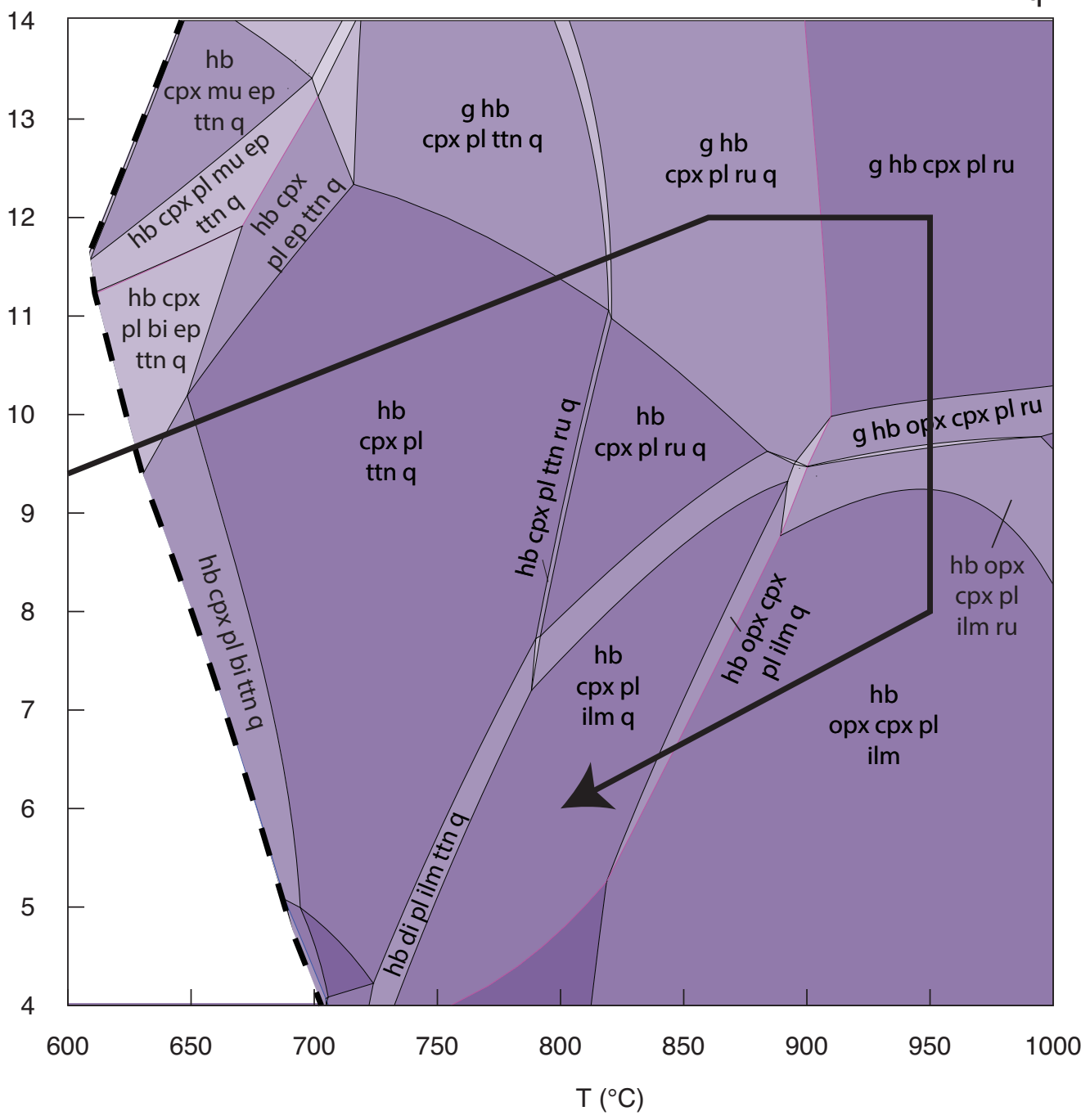

Figure 11 


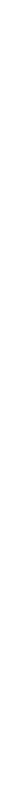

Figure 12 
(a) $T-X$ pseudosection

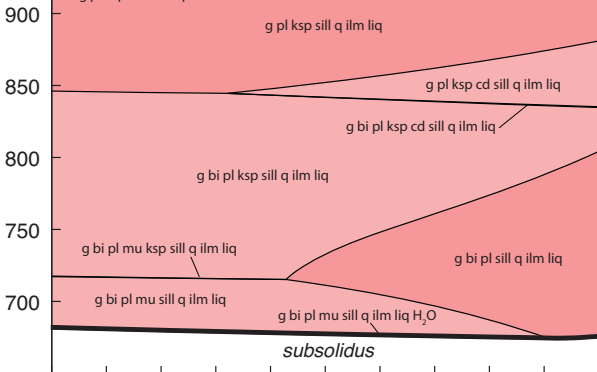

(c) \% dissolution of zircon $(\mathrm{Zr}=150 \mathrm{ppm})$

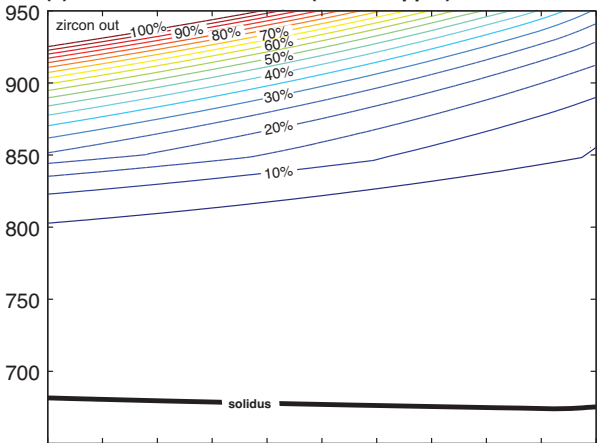

\section{(e) Complete dissolution of zircon}

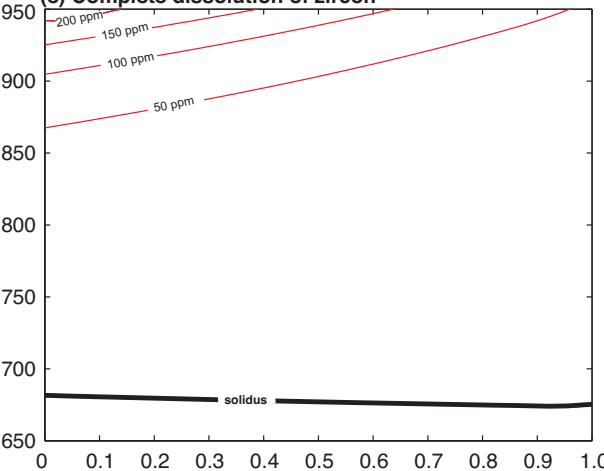

$\uparrow$

Average metapelite

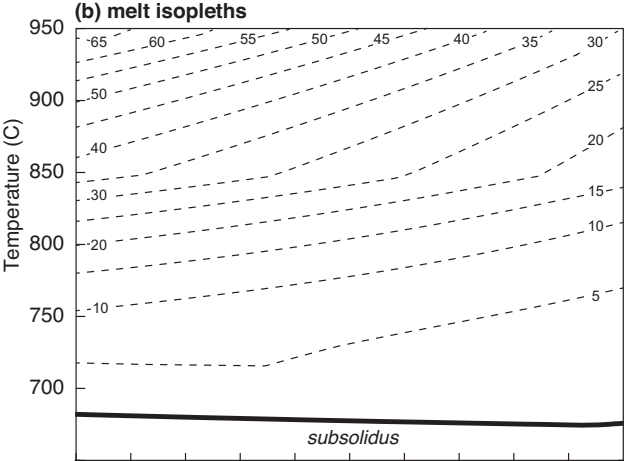

(d) \% dissolution of monazite (LREE = $150 \mathrm{ppm}$ )
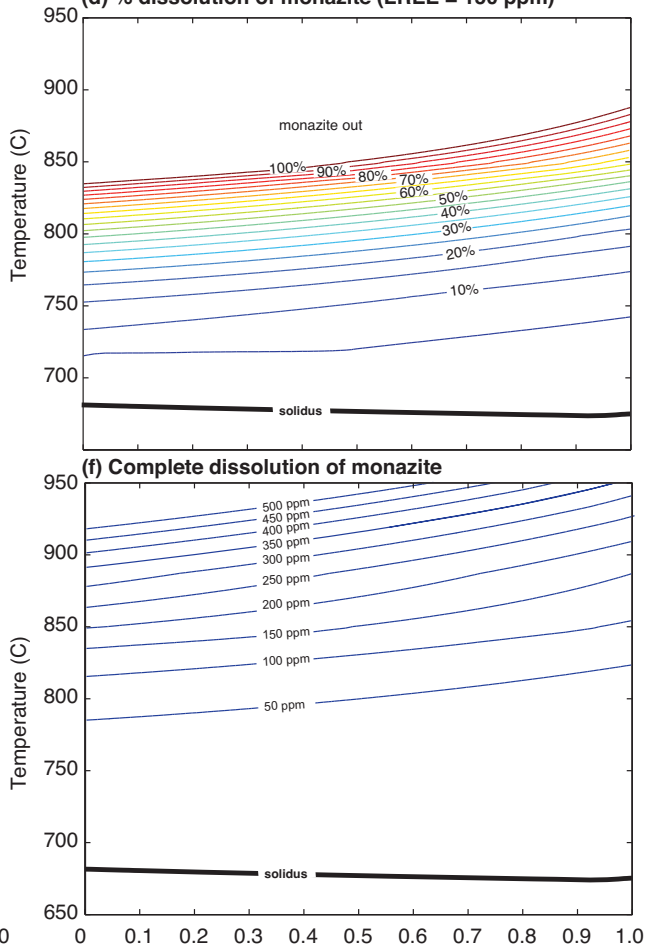

$\uparrow$ Average metapelite 